\title{
Regeneração de plantas de Phaseolus vulgaris $L$. a partir de calos e transformação genética via Agrobacterium
}

\section{Altamir Frederico Guidolin}

Tese apresentada ao Centro de Energia Nuclear na Agricultura, da Universidade de São Paulo, para obtenção do título de Doutor em Ciências, área de concentração: Energia Nuclear na Agricultura. 


\section{Regeneração de plantas de Phaseolus vulgaris $\mathrm{L}$. a partir de calos e transformação genética via Agrobacterium}

\section{Altamir Frederico Guidolin Engenheiro Agrônomo}

Orientador: Profa Dra SIU MUI TSAI Co-orientador: Prof Dr CARLOS ALBERTO LABATE

Tese apresentada ao Centro de Energia Nuclear na Agricultura, da Universidade de São Paulo, para obtenção do título de Doutor em Ciências, área de concentração: Energia Nuclear na Agricultura. 
Dados Internacionais de Catalogação na Publicação (CIP) Seção Técnica de Biblioteca - CENA/USP

\section{Guidolin, Altamir Frederico}

Regeneração de plantas de Phaseolus vulgaris $\mathrm{L}$. a partir de calos e transformação genética via Agrobacterium / Altamir Frederico Guidolin. - - Piracicaba, 2003.

100p. : il.

Tese (doutorado) - - Centro de Energia Nuclear na Agricultura, 2003.

1. Cultura de tecidos vegetais 2 . Feijão 3 . Melhoramento genético vegetal 4. SAAT 5. Sonicação I. Título

CDU 635.652

"Permitida a cópia total ou parcial deste documento, desde que citada a fonte - O autor" 
Aos meus pais Adelmo e Carmem, pelo amor e confiança incondicionais

\section{Ofereço}

Só quem tenta o absurdo é capaz de alcançar o impossível.

Miguel de Unamuno (1864-1936)

A minha esposa Saionara e aos meus filhos Marina e Vitor, pela compreensão nos momentos tomados durante a realização deste trabalho

Dedico 


\section{AGRADECIMENTOS}

A professora $\mathrm{Dr}^{\mathrm{a}}$ Siu Mui Tsai, pela orientação e amizade durante o transcorrer do curso.

Ao professor $\mathrm{Dr}$ Carlos Alberto Labate pela orientação, discussões e disponibilização do laboratório de Genética Fisiológica, o que tornou possível a realização deste trabalho.

A pesquisadora $\mathrm{Dr}^{\mathrm{a}}$ Mônica $\mathrm{T}$. Veneziano Labate pela amizade e pelas valiosas contribuições no desenvolvimento deste trabalho.

Ao grupo de pesquisadores do Laboratório de Genética Fisiológica que contribuíram na troca de idéias e discussões durante o andamento deste trabalho: $\mathrm{Dr}^{\mathrm{a}}$ Mônica T. Veneziano Labate, Dr Esteban Roberto González e Alexander de Andrade.

Aos professores do CENA e da ESALQ pelos ensinamentos.

Ao Eng. Agr. Sérgio Zambon, (Aventis CropScience Brasil Ltda) por ter conseguido o princípio ativo do herbicida Finale (Glufosinato de amônio).

Aos amigos do laboratório Alex, Aline, Érika, Caroline, Felipe, Daniela, Danielle, Gisele, Guillermo, Gunta, Juliano, Karen, Marcelo, Palmira, Paulo, Paulo Barja, Raqueline, Raphael e Valéria pela amizade e agradável convivência durante o desenvolvimento deste trabalho.

Aos amigos Elias, Fábio, Wagner, Chiquinho e Wladecir, pela colaboração e incentivo, especialmente no início do curso. 
Aos amigos Vanoli, Rosa, Oriel, Rose e Rafael Moyses pelos grandes momentos compartilhados.

Ao povo Catarinense que, através da Universidade do Estado de Santa Catarina - UDESC, apoiou financeiramente a minha capacitação.

A CAPES - PICDT pela concessão da bolsa.

A todos que de alguma forma contribuíram para a realização deste trabalho. 


\section{SUMÁRIO}

Página

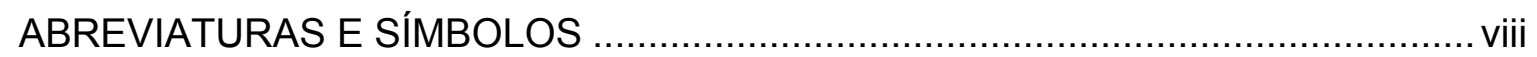

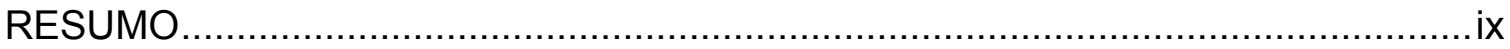

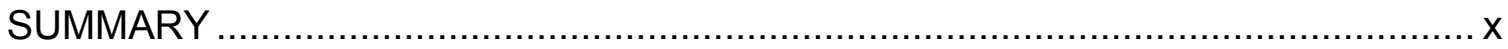

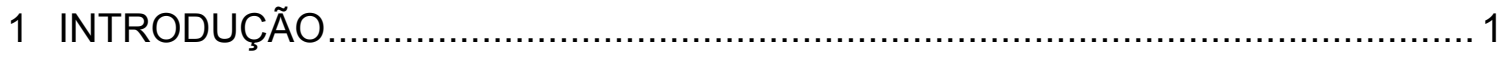

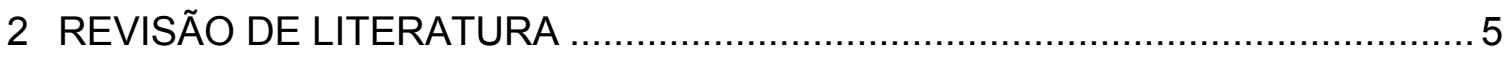

2.1 Cultura de tecidos e regeneração in vitro de plantas ..................................... 5

2.1.1 Reguladores de crescimento ........................................................... 8

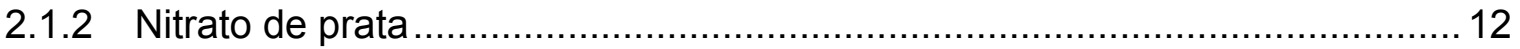

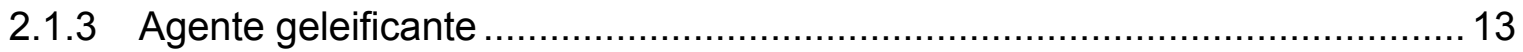

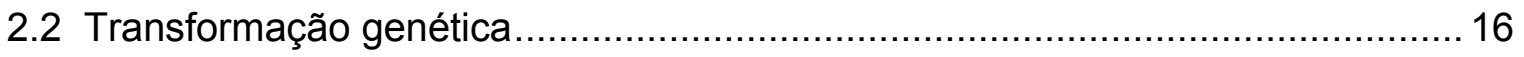

2.2.1 Transferência de DNA para o genoma da planta .................................... 17

2.2.2 A Agrobacterium como vetor de transformação ....................................... 20

2.2.3 Uso da sonicação na transformação genética via Agrobacterium ................. 26

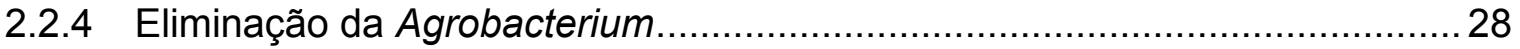

2.2.5 Avaliação da eficiência de transformação ................................................. 28

2.2.6 Seleção de tecidos e plantas transformadas.......................................... 30

3 REGENERAÇÃO DE PLANTAS DE Phaseolus vulgaris L. A PARTIR DE

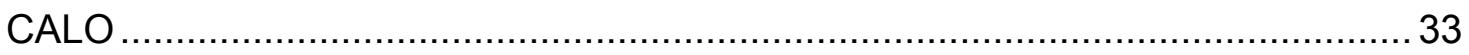

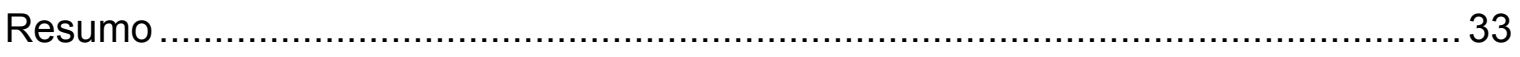

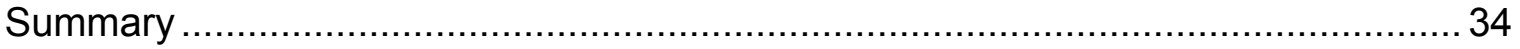

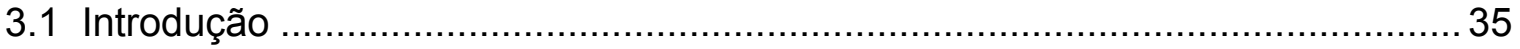

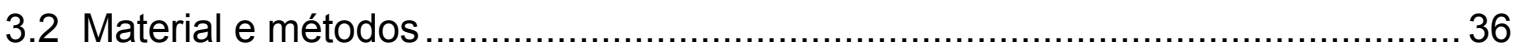

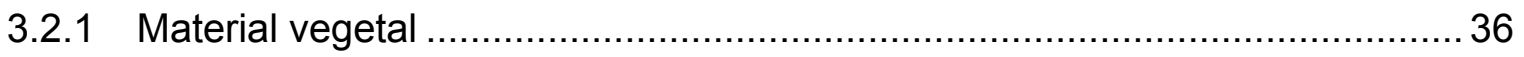

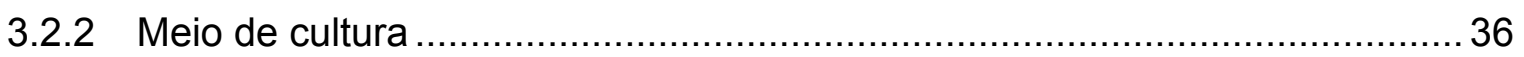




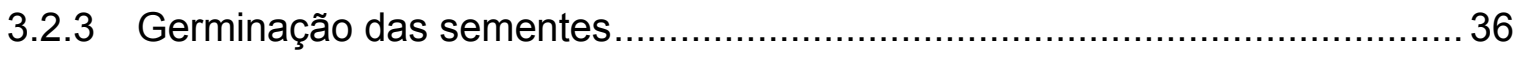

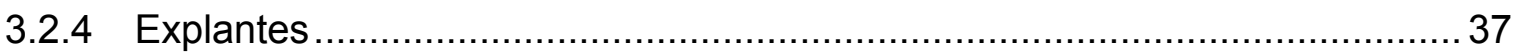

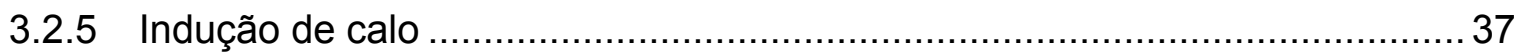

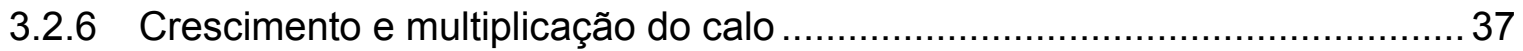

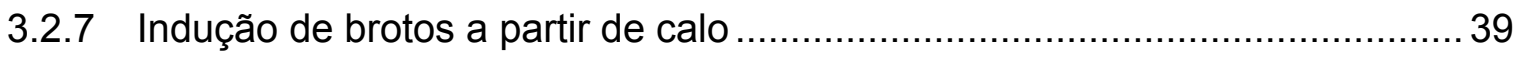

3.2.8 Enraizamento e transplante de brotos regenerados .................................... 40

3.2.9 Aclimatação dos brotos enraizados e produção de sementes ....................... 40

3.2.10 Análise das plantas regeneradas in vitro ..................................................... 41

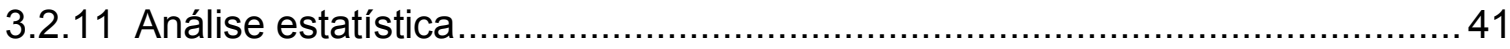

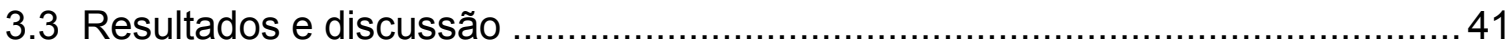

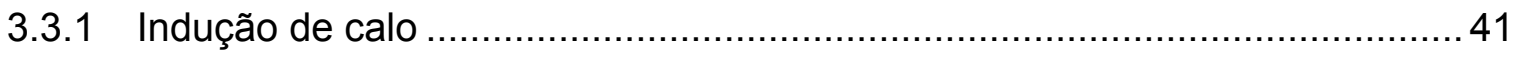

3.3.2 Crescimento e multiplicação do calo ........................................................ 43

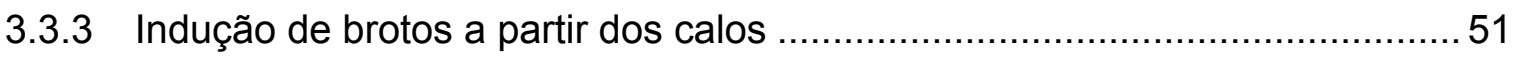

3.3.4 Enraizamento e transplante de brotos regenerados .................................... 57

3.3.5 Análise das plantas regeneradas in vitro .................................................. 59

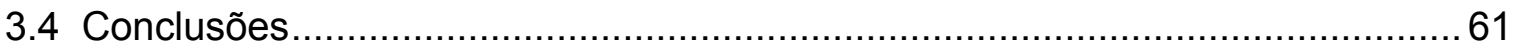

4 TRANSFORMAÇÃO DE CALO ORGANOGENÉTICO DE Phaseolus vulgaris

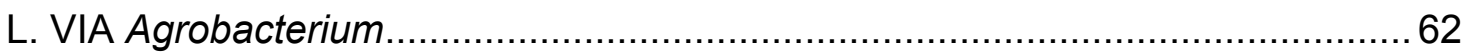

Resumo

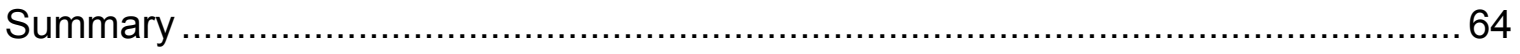

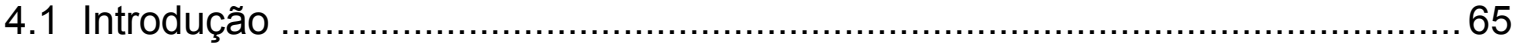

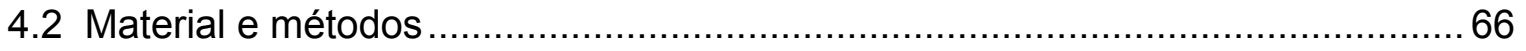

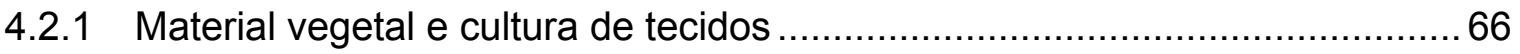

4.2.2 Linhagens de Agrobacterium tumefaciens, plasmídeos e condições de

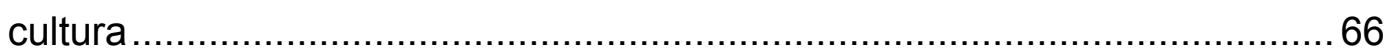

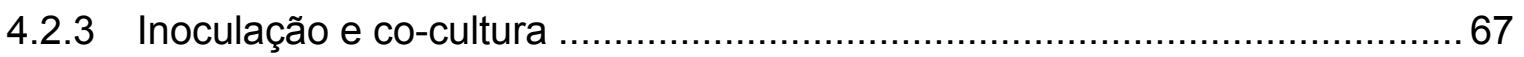

4.2.4 Ensaio histoquímico da $\beta$-glucuronidase para avaliação da eficiência de

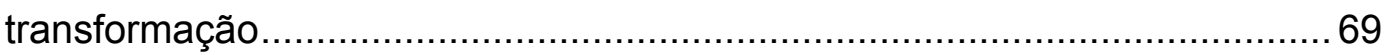

4.2.5 Suscetibilidade de calos de feijão às linhagens de Agrobacterium .................69

4.2.6 Efeito do tempo de duração da sonicação na infecção dos tecidos por

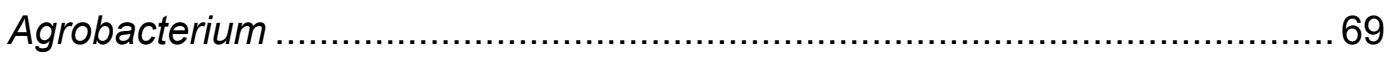

4.2.7 Tolerância dos calos de feijão ao agente seletivo glufosinato de amônio.......70

4.2.8 Eliminação da Agrobacterium dos calos de feijão .......................................... 70 


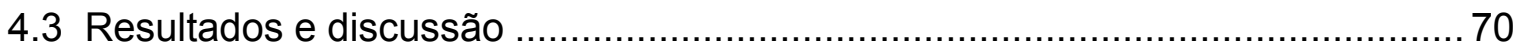

4.3.1 Suscetibilidade de calos de feijão às linhagens de Agrobacterium .................71

4.3.2 Efeito da duração do tempo de sonicação na infecção dos tecidos pela

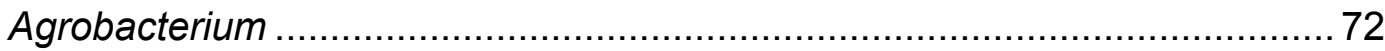

4.3.3 Tolerância de calos de feijão ao agente seletivo glufosinato de amônio ........75

4.3.4 Eliminação da Agrobacterium de calos de feijão.......................................... 76

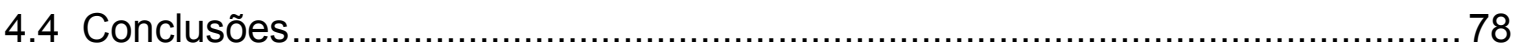

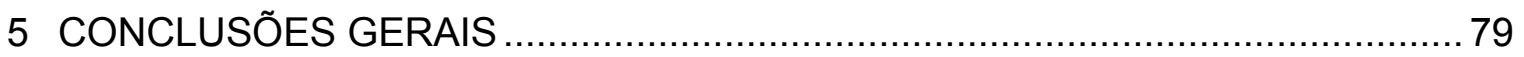

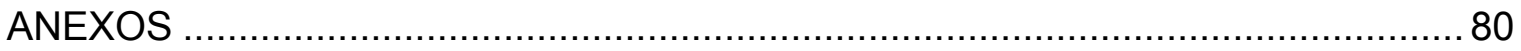

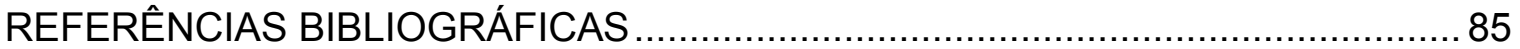




\title{
ABREVIATURAS E SÍMBOLOS
}

\author{
$\mu \mathrm{Em}^{-2} \mathrm{~s}^{-1} \quad$ Micro Einstein por metro quadrado por segundo \\ $\mu \mathrm{M} \quad$ Micro molar \\ $\mu \mathrm{m} \quad$ Micrômetro \\ AIA Ácido 3-indolacético \\ AIB Ácido indolbutírico \\ AL \\ ANA \\ Meio de alongamento de brotos \\ BA \\ Ácido naftalenoacético \\ BAP \\ $\mathrm{CC}$ \\ Meio basal (Sais e myo-inositol do meio MS e Vitaminas do meio B5 \\ 6-benzilaminopurina; BA ( $N^{6}$-Benzyladenine) \\ CPPU \\ Meio de crescimento de calo \\ DMSO \\ Forchlorfenuron; 4-CPPU (N-(2-Chloro-4-Pyridyl)- $N$ '-Phenylurea) \\ DNA \\ Dimethyl sulfoxide (MeSO) \\ $g$ \\ Ácido desoxirribonucléico \\ $\mathrm{GA}$ \\ Unidade de força centrífuga, em atmosferas \\ $\mathrm{GA}_{3}$ \\ Glufosinato de amônio \\ GUS \\ Ácido giberélico \\ $\mathrm{Kb}$ \\ $\beta$-glucuronidase, proteína codificada pelo gene uidA \\ $\mathrm{mg} \mathrm{L}^{-1}$ \\ Kilo base (mil pares de bases nitrogenadas) \\ $\mathrm{mM}$ \\ Miligramas por litro \\ Mili molar \\ MS \\ Meio Murashige \& Skoog (1962); \\ neo \\ Gene da neomicina fosfotransferase (NPTII) \\ OD \\ Densidade ótica \\ PM \\ Peso Molecular \\ rpm \\ $s$ \\ Rotações por minuto \\ TDZ \\ Segundos \\ Thidiazuron; (1-phenil-3-(1,2,3-tidiazol-5-yl) urea)
}




\title{
REGENERAÇÃO DE PLANTAS DE Phaseolus vulgaris A PARTIR DE CALOS E TRANSFORMAÇÃO GENÉTICA VIA Agrobacterium
}

\author{
Autor: ALTAMIR FREDERICO GUIDOLIN \\ Orientador: Prof ${ }^{\mathrm{a}} \mathrm{Dr}^{\mathrm{a}}$ SIU MUI TSAI \\ Co-orientador: Prof Dr CARLOS ALBERTO LABATE
}

\section{RESUMO}

A transformação genética pode contribuir substancialmente para o melhoramento genético do feijão, permitindo a introdução de genes que contribuam para o aumento da produtividade e estabilidade da produção. A metodologia de transformação genética de feijão (Phaseolus vulgaris), ora disponível (biobalística em embriões) apresenta baixa eficiência, o que dificulta o seu uso em pesquisas envolvendo a transferência de genes e não permite seu uso de forma ampla em programas de melhoramento genético da cultura. Um método efetivo e reprodutível de regeneração de plantas, a partir de células ou tecidos, é essencial em estudos de genética e melhoramento envolvendo a transferência de genes pela engenharia genética. Os métodos de transformação somente terão sucesso se tivermos previamente estabelecido um protocolo eficiente de regeneração de plantas a partir de tecidos potencialmente transformáveis. O objetivo principal deste trabalho é o desenvolvimento de um protocolo de transformação genética de feijão via Agrobacterium. O primeiro passo no desenvolvimento deste protocolo foi 0 estabelecimento de um sistema eficiente de regeneração de plantas a partir de calos. O passo seguinte foi o estabelecimento de metodologia da transformação de calos via Agrobacterium. 


\title{
PLANT REGENERATION FROM CALLUS OF Phaseolus vulgaris AND GENETIC TRANSFORMATION VIA Agrobacterium
}

\author{
Author: ALTAMIR FREDERICO GUIDOLIN \\ Adviser: $\operatorname{Prof}^{\mathrm{a}} \mathrm{Dr}^{\mathrm{a}}$ SIU MUI TSAI \\ Co-adviser: Prof Dr CARLOS ALBERTO LABATE
}

\section{SUMMARY}

The genetic transformation can contribute substantially with the bean (Phaseolus vulgaris L.) breeding, allowing the introduction of genes to improve productivity and its stability. The transformation methodology of bean, now available (biolistic in embryos), is not efficient, which prevents its use in bean breeding programs. A reproducible and effective method of plant regeneration, from cells or tissues is essential in genetics studies and plant breeding, involving the genetic engineering. The transformation methods will only work if we can previously establish an efficient plant regeneration protocol from tissues with potential for transformation. The aim of this work was to develop an efficient transformation protocol of bean via Agrobacterium. The first step was to establish an efficient system of plant regeneration from callus, followed by the establishment of a transformation methodology via Agrobacterium. 


\section{INTRODUÇÃO}

O feijão (Phaseolus vulgaris L.) é uma leguminosa anual, predominantemente autógama, domesticada a mais de 7000 anos em dois centros de origem: a Mesoamérica (México e a América Central) e a região Andina. Acredita-se que o feijão, juntamente com o milho e a abóbora, começou como erva daninha em cultivos de mandioca e batata-doce, na América Central. Durante milênios os agricultores cultivaram misturas complexas de tipos de feijão como cerca viva contra seca, doenças e ataques de pragas. Este processo produziu uma variabilidade genética quase ilimitada, com uma variedade grande de cores, textura e tamanho de grão, vindo ao encontro das condições de plantio e preferências de sabor, de diferentes regiões. Os diversos tipos de feijão são cultivados desde o nível do mar até mais de três mil metros de altitude, principalmente por pequenos agricultores com menos de um hectare, sem irrigação, que usam pouco ou nenhum tipo de fertilizante ou pesticida (Schoonhoven \& Voysest, 1991).

Entre as espécies leguminosas o feijão é uma das que tem o cultivo mais difundido no mundo, em particular em países da Ásia, África e América Latina, onde representa uma das principais fontes calórico-protéica para cerca de 500 milhões de pessoas. Na maior parte destes países a proteína de origem vegetal chega a mais de 80\% do total de proteínas da dieta humana (Brown et al., 1990; Araujo et al., 1996). Nutricionistas caracterizam o feijão como um alimento quase perfeito devido ao alto conteúdo de proteínas e fibras, carboidratos complexos e outros complementos da dieta como ácido fólico (fonte de vitamina B), ferro, zinco, magnésio e potássio (CIAT, 2002). O consumo médio per capita é de aproximadamente 11 quilos por pessoa por ano, dependendo do país e do nível econômico do consumidor. O consumo per capita de feijões é mais alto em países muito pobres, como a Nicarágua (22,5 quilogramas 
per capita por ano), e em regiões mais pobres de países de renda mais altas, como o nordeste brasileiro, com 18,5 quilogramas per capita por ano (CIAT, 2002).

O feijão é a segunda cultura em área plantada no mundo, sendo superado apenas pelo milho. A produção anual é superior a 12 milhões de toneladas, das quais quase metade é produzida na América Latina. A maior parte da produção de feijão ocorre em solos com declives íngremes, propensos à erosão e com baixa fertilidade. $O$ Brasil é o segundo maior produtor mundial de feijão quando se engloba todos os gêneros e espécies de feijões, e o maior produtor mundial quando se trata apenas do gênero Phaseolus (Vieira et al., 1998).

Por predominar o cultivo em pequenas propriedades o feijão apresenta destaque na absorção de mão de obra agrícola, especialmente a mão de obra familiar. Estima-se que esta cultura utilize cerca de 40 milhões de homem dia ${ }^{-1}$ por ciclo de produção. No final do ultimo século houve migração das populações rurais mais pobres para as grandes cidades, as quais já concentram mais de $70 \%$ da população da América Latina. Frente às tendências atuais de crescimento da população e do consumo de feijão, pode ser esperado um aumento da demanda, para a América Latina e África, a níveis sem precedentes. Este aumento pela demanda será suprido somente se novos cultivares de feijão com rendimentos mais altos, resistência múltipla a doenças e maior tolerância à seca e baixa fertilidade do solo forem desenvolvidos, pois isto permitirá aumentar-se a produtividade de feijão, alcançando-se assim maior estabilidade de rendimento (CIAT, 2002).

A utilização de técnicas de manejo, mecanização e cultivo na entressafra promoveu um aumento sistemático da produtividade brasileira na última década. $\mathrm{O}$ Brasil, grande produtor e consumidor mundial de feijão, têm como centros de produção os Estados do Paraná, Bahia, Minas Gerais, São Paulo, Santa Catarina, Rio Grande do Sul e Goiás. Nos últimos anos, a agricultura empresarial tem se fortalecido e investido em lavouras mais modernas e de maior extensão, abastecendo períodos antes denominados entressafra (Santos \& Braga, 1998). Um exemplo é o número de produtores brasileiros que utilizam irrigação e colheita semi-mecanizada que embora tenha aumentado, estão desestimulados principalmente pelo risco econômico devido à alta suscetibilidade a pragas e doenças, pouca tolerância à seca e à baixa 
produtividade; fatores que em conjunto ocasionam uma produção instável durante os anos. Mesmo os novos produtores que têm surgido com as mudanças no mercado e que estão dispostos a investir na cultura necessitam de novas variedades melhoradas e adaptadas ao uso de fertilizantes e a colheitas semi-mecanizadas.

O melhoramento genético de feijão tem como finalidades principais desenvolver germoplasma básico para lavouras que utilizem tecnologia e para lavouras de baixa ou nenhuma tecnologia e; estabelecer estratégias para o manejo de pragas e doenças em ambos sistemas de semeadura, as quais culminem com o lançamento de novas variedades adaptadas a condições específicas. Embora o melhoramento de feijão tenha dado excelentes resultados nas últimas décadas, para acelerar o progresso do árduo trabalho de produção de novas variedades, é necessária a busca de genes valiosos em espécies selvagens de Phaseolus e em espécies distantes, relacionadas ou não com o feijão. Muitos genes de interesse ao melhoramento genético, como os de resistência a pragas e doenças, não estão disponíveis, visto as barreiras de cruzamentos interespecíficos. Algumas destas barreiras podem ser rompidas com o auxílio de técnicas como o resgate de embriões, associado a séries de retrocruzamentos planejados. Esta estratégia de introgressão de genes além de muito demorada e cara está limitada a algumas espécies selvagens mais próximas (CIAT, 2002). O CIAT vem trabalhando nesta linha de pesquisa desde 1980, obtendo sucesso na introgressão de alguns genes como a resistência ao complexo comum bacteriano, ao gafanhoto e à seca; o que é ainda considerado pouco em relação às atuais necessidades do melhoramento genético.

Devido à crescente demanda por novas variedades, os programas de melhoramento genético têm buscado tecnologias que acelerem o desenvolvimento de variedades ou que possibilitem corrigir pequenos defeitos das que estão em uso, como a suscetibilidade a determinados patógenos, no menor tempo possível. Entre as ferramentas com potencial para acelerar o desenvolvimento de novas variedades está a transformação genética, possibilitando a introdução de genes de espécies afins ou mesmo de espécies mais distantes. A introdução de genes adequados traz esperanças de auxiliar na solução de problemas como a suscetibilidade a doenças, a pragas e as deficiências nutricionais, além de possibilitar mudanças em características como a eficiência fotossintética e a arquitetura das plantas. Para isto é necessário o 
desenvolvimento de protocolos eficientes, os quais permitam estudos genéticos básicos e aplicados.

O feijão, bem como a maioria das leguminosas, apresenta dificuldades para a transformação genética. As dificuldades vão desde a introdução do gene até a regeneração de plantas, passando por problemas como a falta de reprodutibilidade, aplicabilidade a todas as variedades e à baixa eficiência de transformação (Nagl et al., 1997).

A metodologia ora disponível para transformação genética de feijão utiliza o meristema apical de embriões maduros como tecido alvo para a regeneração das plantas transformadas por biobalística. A metodologia apresenta baixa eficiência de transformação (menos de $1 \%$ ), e as plantas transformadas podem conter apenas fragmentos do DNA alvo ou até mesmo introduzir um grande número de cópias no genoma da planta transformada (Aragão et al., 1996; Aragão \& Rech, 1997; Aragão et al., 1999; Aragão et al., 2000).

O presente trabalho tem como objetivo o desenvolvimento de um sistema de transformação genética de Phaseolus vulgaris via Agrobacterium tumefaciens, que permita a introdução de genes de interesse na cultura. Assim, a primeira etapa do trabalho resultou no desenvolvimento de um sistema de regeneração indireta de plantas de feijão, a partir de calos e; a segunda etapa compreende o desenvolvimento de um sistema de transformação de calo organogenético de feijão via Agrobacterium. 


\section{REVISÃO DE LITERATURA}

O desenvolvimento de técnicas de obtenção de plantas a partir do cultivo in vitro de órgãos, tecidos e células e o desenvolvimento de protocolos de transferência de genes entre espécies incompatíveis sexualmente, permitem ao melhorista utilizar a variabilidade genética limitada pelas barreiras do isolamento reprodutivo, possibilitando o desenvolvimento de genótipos até então não obtidos.

Dada a importância do feijão, vários grupos de pesquisa de diversos países vêm trabalhando com a cultura de tecidos nos últimos 30 anos, no entanto os resultados são pouco satisfatórios. Embora alguns trabalhos relatem a regeneração de plantas de feijão (Crocomo et al., 1976), os resultados não apresentam reprodutibilidade, e em outros, os métodos desenvolvidos são restritos a poucos genótipos, com eficiência de regeneração bastante baixa, impossibilitando sua aplicação em um programa de melhoramento que utilize a engenharia genética (Nagl et al., 1997). Grupos de pesquisa em outras culturas contornaram este problema infectando tecidos meristemáticos com Agrobacterium. Deste modo, plantas transgênicas de petúnia (Ulian et al., 1988), milho (Gould et al., 1991), ervilha (Hussey et al., 1989) e Arabidopsis foram obtidas através da inoculação de Agrobacterium tumefaciens diretamente no meristema. Outra maneira de contornar a ausência de regeneração é a utilização da técnica de aceleração de partículas em meristemas, a qual permitiu a obtenção de plantas transgênicas de feijão (Russell et al., 1993; Aragão et al., 1993).

\subsection{Cultura de tecidos e regeneração in vitro de plantas}

A habilidade de fazer com que células de plantas formem órgãos e até plantas inteiras é uma importante ferramenta no melhoramento de qualquer espécie, 
permitindo o acesso a técnicas como a mutagênese in vitro, seleção in vitro, utilização de variantes somaclonais, rápida micropropagação e em especial a transformação genética (Gamborg \& Phillips, 1995).

Para experimentos em larga escala, a tecnologia de transferência de genes requer sistemas eficientes de regeneração de plantas através da cultura de tecidos. A regeneração de plantas pode ocorrer, a princípio, por duas principais rotas, as quais são geralmente bem distintas: a organogênese e a embriogênese. A organogênese geralmente se dá pela otimização da relação citocinina : auxina no meio de cultura e ocorre pela diferenciação de órgãos e brotos diretamente do explante (organogênese direta) ou do calo (organogênese indireta) podendo originar-se de uma única célula ou de um conjunto de células. A organogênese caracteriza-se por ser uma estrutura monopolar e apresenta ampla conexão vascuolar dos órgãos formados com 0 explante. A embriogênese somática geralmente é induzida por tratamento com auxinas potentes e resulta na formação de estruturas não zigóticas semelhantes a um embrião, tendo sua origem uni ou multicelular, de células pré-embriogênicas determinadas (embriogênese direta) ou de células embriogênicas determinadas induzidas (embriogênese indireta). A embriogênese caracteriza-se principalmente por apresentar estrutura bipolar e sistema vascular fechado (Thorpe, 1995).

Para a regeneração de plantas inteiras é fundamental encontrar tecidos na planta que ainda retenham a totipotencialidade celular. Durante muitos anos os meristemas apicais e axilares e as sementes imaturas ou em germinação foram os tecidos que mais contribuíram para a cultura de tecidos. Na regeneração de muitas espécies os avanços se deram na otimização dos meios de cultura e escolha de genótipos. A escolha de uma citocinina em relação à outra, níveis e relações entre hormônios e outros componentes do meio, tempo de cultura de certos estágios e meio basal utilizado tiveram papel importante no desenvolvimento de muitos protocolos. As leguminosas de um modo geral são de difícil regeneração a partir de cultura de tecidos e têm provado isto desde o início das primeiras tentativas por Hildebrandt et al. (1963) e Crocomo et al. (1976). Entretanto tem se obtido grande progresso em algumas culturas como a da soja e a da ervilha (Grant et al., 1995; Di et al., 1996). 
A indução de embriogênese somática e a diferenciação de pró-embriões tem sido obtida em cultura de tecidos (Allavena \& Rossetti, 1983; Martins \& Sondahl, 1984; Saunders et al., 1987) e de calos derivados de cotilédones (Mohamed et al., 1993a) de feijão. Porém a dificuldade em se obter plantas de feijão não tem permitido o sucesso destas metodologias. O feijão também tem sido pouco responsivo à regeneração de plantas a partir da organogênese indireta e, como conseqüência, a transformação genética fica limitada. Os poucos protocolos de regeneração de Phaseolus publicados não apresentam boa reprodutibilidade devido à dificuldade em se regenerar plantas (Nagl et al., 1997).

Plantas de Phaseolus acutifolius foram regeneradas a partir de suspensão de células de calos originados de folhas (Kumar et al., 1988). Já no caso de Phaseolus coccineus foram regeneradas a partir de calos de cotilédones imaturos (Angelini \& Allavena, 1989) e plantas de Phaseolus polyanthus foram regeneradas a partir de calos de plântulas germinadas in vitro (Zambre et al., 2001).

A cultura de tecidos em Phaseolus vulgaris desenvolveu-se a partir da cultura de meristemas (Kartha et al., 1981), seguida pela propagação via proliferação de brotos axilares de ápices e nós cotiledonares (Saam et al., 1987; Malik \& Saxena, 1991; Malik \& Saxena, 1992), regeneração de brotos de pecíolo de folhas (Malik \& Saxena, 1991), explantes cotiledonares ou cultura de eixos embrionários (Mohamed et al., 1992b), organogênese direta a partir de nós de plântulas, sem a presença de meristemas axilares (Mcclean \& Grafton, 1989; Mohamed et al., 1992a) ou em presença de meristemas axilares (Franklin et al., 1991) e, recentemente, com o uso de camadas finas transversais "transverse thin cell layer (tTCL)", utilizadas na regeneração direta de plantas de Phaseolus vulgaris variedade Carioca (De Carvalho et al., 2000).

Embora várias combinações de hormônios, explantes e condições de cultura tenham sido avaliadas exaustivamente na tentativa de se obter suspensões celulares e calos em Phaseolus vulgaris, não foi possível chegar à planta a partir dos embrióides (Nagl et al., 1997). A produção de brotos a partir de calos se restringe a poucos trabalhos. O trabalho pioneiro foi o de Crocomo et al. (1976), que regeneraram duas plantas de cultura de calos usando meio de cultura suplementado com 
reguladores de crescimento e um extrato aquoso de sementes de feijão. Outros dois trabalhos, que relatam a utilização de combinações de TDZ (Thidizuron, uma citocinina do grupo das feniluréias) e AIA (ácido indolacético) também obtiveram plantas. Mohamed et al. (1993) regeneraram plantas a partir de calos primários induzidos em pedicelos de dois genótipos de Phaseolus vulgaris L. (Xan 159 e GN Tara) e; Zambre et al. (1998) regeneraram plantas a partir de calos induzidos na região de ligação do cotilédone com o eixo embrionário (Xan 159). Ambos os genótipos utilizados são provenientes de cruzamentos interespecíficos com Phaseolus acutifolius A. Gray. Pode ser que haja, neste caso, um fator genético herdado de $P$. acutifolius que favoreça a regeneração de plantas a partir de calos (Mohamed et al., 1993b).

Dillen et al. (1996), utilizando metodologia semelhante a utilizada por Mohamed et al. (1993), regeneraram plantas a partir de Phaseolus acutifolius e posteriormente obtiveram plantas transformadas via Agrobacterium (Dillen et al., 1997).

A obtenção de plantas de Phaseolus vulgaris transformadas geneticamente via Agrobacterium ainda não foi possível, principalmente pela falta de reprodutibilidade e baixa eficiência das metodologias de regeneração de plantas a partir de calos. Alguns autores sugerem que a falta de reprodutibilidade da metodologia poderia ser solucionada utilizando-se explantes produzidos a partir de sementes maduras germinadas in vitro. Estes explantes seriam confiáveis e produziriam calos com maior confiabilidade e eficiência (Mohamed et al., 1993b; Zambre et al., 1998).

A regeneração de plantas a partir de calos pode levar ao surgimento de variação somaclonal propiciando o surgimento de variantes úteis. Este método pode aumentar a variabilidade genética disponível para o melhorista, além de permitir a seleção in vitro, estudos fisiológicos, obtenção de produtos secundários e a transformação genética via Agrobacterium (Gamborg \& Phillips, 1995).

\subsubsection{Reguladores de crescimento}

A composição e a concentração dos reguladores de crescimento no meio de cultura são fatores determinantes para o crescimento e para o padrão de desenvolvimento da maioria dos sistemas de cultivo in vitro. As auxinas e as citocininas são as classes de reguladores de crescimento mais utilizadas em cultura de tecidos. 
As citocininas apresentam um papel importante na regulação da divisão celular e interagem com as auxinas no controle de muitos aspectos do crescimento e do desenvolvimento das plantas. A formação das raízes, parte aérea e calo em cultura de tecidos são reguladas pela disponibilidade e interação dessas duas classes de reguladores de crescimento (Frank \& Schmülling, 1999). São caracterizadas principalmente pela habilidade de promover a proliferação celular e a diferenciação dos tecidos. As citocininas estão envolvidas também na diferenciação de cloroplastos, metabolismo de nutrientes, quebra da dominância apical e retardamento da senescência das folhas. Apesar de sua grande importância, quase nada é conhecido a respeito do mecanismo de ação ao nível molecular. As citocininas podem ser classificadas em dois grupos: citocininas - adeninas e citocininas - feniluréias (Takahashi et al., 1978; Mok et al., 1982; Gonneau et al., 1998).

O grupo das feniluréias que apresentam atividade de citocinina pode ser dividido em pelo menos dois subgrupos: as tiadiazoliuréias e as piridiluréias. Estes compostos desempenham alta atividade de citocinina, que equivalem ou mesmo excedem às mais potentes citocininas do grupo das adeninas, como a zeatina, o BAP e a cinetina (Takahashi et al., 1978; Mok et al., 1982; Thomas \& Katterman, 1986). O TDZ é um composto do grupo das tiadiazoliuréias enquanto que o forchlorfenuron (CPPU) é um composto do grupo das piridiluréias. Ambos apresentam forte atividade de citocinina.

\section{Thidiazuron}

O TDZ é um herbicida descrito em muitos trabalhos como um regulador de crescimento que apresenta efeitos semelhantes às citocininas, sendo muito eficiente na micropropagação de várias espécies, principalmente arbóreas ou florestais (Huetteman \& Preece, 1993). O thidiazuron foi primeiramente utilizado como desfoliante de algodão (Mok et al., 1982; Mok \& Mok, 1985). A indução da abscisão das folhas pelo TDZ ocorre, pelo menos em parte, através do aumento dos níveis endógenos de etileno (Suttle, 1985). É utilizado na quebra de dormência em maçã, a qual está associada ao aumento de DNA, RNA e proteínas, responsáveis pela transição do estado de dormência para o estado biologicamente ativo (Wang et al., 
1986). Em Cydonia oblonga L. preveniu a senescência de folhas e induziu a formação de gemas axilares com mais eficiência, quando comparado ao BAP.

A propriedade biológica do TDZ como regulador de crescimento em cultura de tecidos foi demonstrada primeiramente em calos de Phaseolus lunatus por Mok et al. (1982). Nesse caso, o TDZ estimulou a produção de calo, com ação superior a todos os demais compostos avaliados. Tem apresentado bons resultados em diferentes protocolos de regeneração de plantas de algumas leguminosas consideradas recalcitrantes, como ervilha, grão de bico e lentilha (Malik \& Saxena, 1992), amendoim (Gill \& Saxena, 1992; Murthy \& Saxena, 1994; Akasaka et al., 2000), fava (Mohamed et al., 1992a; Khalafalla \& Hattori, 1999; Khalafalla \& Hattori, 2000), feijão caupi e também em algumas espécies do gênero Phaseolus (Mohamed et al., 1992a; Malik \& Saxena, 1992; Mohamed et al., 1993b; Zambre et al., 1998; De Carvalho et al., 2000; Zambre et al., 2001).

De Carvalho et al. (2000) utilizando TDZ na regeneração de plantas de feijão observaram efeitos inibitórios ao desenvolvimento de brotos e ao enraizamento de explantes submetidos a exposições prolongadas em altas concentrações (4 semanas a $10 \mu \mathrm{M})$. A contínua exposição de explantes ao TDZ nem sempre é necessária, pois as culturas podem adquirir auto-suficiência depois de determinado tempo sob contato (Capelle et al., 1983; Malik \& Saxena, 1992; De Carvalho et al., 2000). Murch \& Saxena (2001) trabalhando com reguladores de crescimento radiomarcados observaram que tecidos tratados com TDZ apresentavam concentrações de AIA mais elevados do que o meio de cultura, além desta auxina ser translocada a maiores distancias dentro dos tecidos. Esta feniluréia permaneceu intacta dentro dos tecidos da planta tanto na forma livre como conjugada. Segundo estes autores, os dados fornecem as primeiras evidências de que a molécula de TDZ permanece intacta, tanto na forma livre como na forma conjugada, dentro dos tecidos vegetais. Também fornece evidências de que a exposição ao TDZ aumenta o acúmulo e translocação das auxinas dentro dos tecidos vegetais.

\section{Forchlorfenuron}

O Forchlorfenuron (CPPU), uma feniluréia modificada, é utilizado para retardar o amadurecimento e para aumentar o tamanho e a produção de frutos em 
culturas como uva, maçã, kiwi, entre outras (Reynolds et al., 1992), podendo também causar abscisão e/ou deformação de frutos (Greene, 2001). Embora tenha grande potencial na regulação da divisão celular e do crescimento, conhecido há décadas, seu uso na cultura de tecidos é mais recente. Um dos primeiros relatos do uso do CPPU em cultura de tecidos vegetais foi no estímulo da proliferação de brotos em ápices meristemáticos de azáleas (Fellman et al., 1987). Posteriormente Mohamed et al. (1992) utilizaram CPPU na indução da organogênese direta em explantes de nó de plântulas de feijão e de fava. O número de brotos por explante formados foi de duas a cinco vezes maior em meio de cultura acrescido de 0,25 $\mu \mathrm{M}$ de CPPU ou TDZ, em relação ao acrescido de $5 \mu \mathrm{M}$ de BAP. Em altas concentrações $(2,5 \mu \mathrm{M}$ CPPU e $5 \mu \mathrm{M}$ TDZ) houve inibição da formação de brotos e estimulo da formação de calos. Análises histológicas indicam que meristemas adventícios se formaram 6 a 8 dias após a cultura dos explantes.

O CPPU tem apresentado bons efeitos no meio de cultura, com respostas variadas como a organogênese, indução de calos e formação de embriões somáticos (Sriskandarajah et al., 2001; Fiore et al., 2002), principalmente de espécies consideradas recalcitrantes à regeneração.

As feniluréias em geral apresentam grande capacidade de estimular a divisão celular em culturas de calos. $\mathrm{Na}$ indução de brotos de tabaco apresentou um efeito 10 vezes superior ao BAP (Takahashi et al., 1978). Assim como outras citocininas sintéticas, as feniluréias são menos suscetíveis à degradação enzimática pela planta, quando comparada às citocininas endógenas (Huetteman \& Preece, 1993). Seu uso está associado, em alguns casos, à vitrificação, morfologia anormal de folhas, gemas mal formadas e diminuição ou ausência do enraizamento (Briggs et al., 1988; Huetteman \& Preece, 1993; Leshem et al., 1994). Podem estar envolvidas na síntese e/ou acúmulo de citicininas em cultura de tecidos (Capelle et al., 1983; Allavena \& Rossetti, 1983). Em estudos da regulação do metabolismo observou-se que o CPPU, assim como outras citocininas, retardam a biossíntese do ácido abscísico (ABA) (Cowan et al., 1999). O mecanismo pelo qual as feniluréias respondem de maneira equivalente as citocininas do grupo das adeninas permanece pouco conhecido, assim como os mecanismos de recepção/transdução das demais citocininas (Gonneau et al., 1998). 


\subsubsection{Nitrato de prata}

A regeneração de algumas leguminosas consideradas recalcitrantes tem se tornado efetiva após a introdução das feniluréias na cultura de tecidos, embora alguns problemas persistam. Um deles é a falta de enraizamento nos brotos desenvolvidos em presença destes hormônios, que em espécies como Phaseolus vulgaris, $P$. acutifolius $P$. polyanthus estão sendo contornados com enxertia dos brotos em plântulas. Entretanto isso resulta em uma baixa eficiência do protocolo de regeneração (Mariotti et al., 1989; Mcclean \& Grafton, 1989; Franklin et al., 1991; Mohamed et al., 1992a; Mohamed et al., 1993b; Dillen et al., 1997; Zambre et al., 1998; Zambre et al., 2001). Recentemente este problema tem sido contornado com o uso de nitrato de prata, que segundo Beyer (1976) é um potente inibidor de etileno em plantas. O nitrato de prata inibe a ação do etileno através dos íons $\mathrm{Ag}^{+2}$ reduzindo a capacidade do receptor ligarse ao etileno (Yang, 1985). Khalafalla et al. (2000) mostraram que inibidores de etileno, como o nitrato de prata, atuam no enraizamento de brotos de fava regenerados em presença de thidiazuron, antecipando a formação, aumentando a taxa de crescimento e o número de raízes formadas, o que abre perspectivas para melhorar os protocolos que utilizam as feniluréias e apresentam inibição do enraizamento (Khalafalla \& Hattori, 2000). Corroborando com estes resultados, De Carvalho et al. (2000) conseguiram plantas de Phaseolus vulgaris por organogênese direta utilizando nitrato de prata, sem problemas na indução de enraizamento $(80 \%$ dos plantas regeneradas enraizaram na presença de $1 \mu \mathrm{M}$ de $\mathrm{ANA}$ e $10 \mu \mathrm{M}$ de $\mathrm{AgNO}_{3}$ ).

Nordström \& Eliasson (1993) observaram que o enraizamento em ervilha é dependente do AIA proveniente das regiões apicais do ramo cortado. Para o enraizamento normal devem ser mantidos níveis de AIA acima de um certo nível mínimo. A adição de AIA $(10 \mu \mathrm{M})$ e tiossulfato de prata $(10 \mu \mathrm{M})$ promoveram um estímulo pronunciado, formando raízes na região do corte e também ao longo do entrenó.

O etileno apresenta vários efeitos morfogenéticos no desenvolvimento das plantas. Pode promover a formação de raízes adventícias e também mediar o efeito de fatores de enraizamento como as auxinas (Bleecker \& Kende, 2000). Genes que codificam proteínas associadas ao amolecimento da parede celular, durante o 
amadurecimento de frutos, enzimas hidrolíticas que dissolvem a parede celular durante a abscisão (como a abertura de órgãos para liberar sementes), proteínas induzidas por ferimentos em resposta a patógenos e proteinases que agem durante a senescência das folhas contém elementos promotores que estão sob regulação do etileno (Bleecker \& Kende, 2000).

O uso de agentes bloqueadores da síntese de etileno ou de sua ação foi benéfico na cultura de anteras de Brassica oleracea. Entretanto, em casos como a cevada, ficou provado que a cultura de anteras libera etileno no meio de cultura e que níveis específicos deste gás estimulam a embriogênese, a qual é interrompida pelo uso de inibidores de etileno (Thorpe, 1995).

Em feijão, o nitrato de prata mostrou efeito sinergistico com o BAP em concentração equimolar $(10 \mu \mathrm{M})$, aumentado o número e o comprimento de brotos na regeneração de Phaseolus vulgaris. Outras concentrações de nitrato de prata foram avaliadas, em presença ou não de BAP, e não mostraram efeito (De Carvalho et al., 2000). Resultados semelhantes foram obtidos na indução de morfogênese em explantes do nó cotiledonar de Phaseolus vulgaris cultivados em meio MS suplementado com $1 \mathrm{mg} \mathrm{L}^{-1}$ de BAP, acrescido de inibidores de etileno (Hoyos \& Hosfield, 1995). Espécies de Vigna, consideradas recalcitrantes, também puderam ser regeneradas utilizando inbidores de etileno (Brar et al., 1999). A produção de etileno pode ser a principal razão do fracasso na regeneração eficiente de espécies leguminosas consideradas recalcitrantes (De Carvalho et al., 2000).

\subsubsection{Agente geleificante}

Os dois tipos de agente geleificante mais comumente utilizados na cultura de tecidos vegetais são o agar (ou sua forma purificada, a agarose) extraído da alga Laminaria e a goma "gellan" também conhecido como Gelrite ou Phytagel, um polissacarídeo extracelular produzido por Pseudomonas elodea (Laine et al., 2000).

A vitrificação (hiperhidria) é considerada um efeito marcadamente relacionado ao agente geleificante. Na presença de gellan ocorre maior propensão a vitrificação dos tecidos cultivados in vitro (Franck et al., 1998). Já no caso do agar, um dos componentes, provavelmente um oligossacarídeo (Marga et al., 1997) ou um tipo 
de agaroide xilogalactano (Nairn et al., 1995) previne a ocorrência da vitrificação. Alguns tipos comerciais de agente geleificante podem controlar a vitrificação por conter determinados componentes ou aditivos, os quais podem também causar sintomas tóxicos aos tecidos em cultivo (Nairn et al., 1995).

Para combinar as vantagens de ambos os geleificantes ou minimizar suas desvantagens e reduzir a ocorrência de vitrificação em espécies susceptíveis, misturas de agar e gellan estão disponíveis comercialmente, como por exemplo o Agargel Sigma.

$O$ agente geleificante interfere na habilidade do meio de cultura em induzir a resposta desejada no cultivo in vitro, como a formação de brotos e o enraizamento (Hadeler et al., 1995). O aumento das concentrações do agente geleificante afeta vários parâmetros da cultura de tecidos, em especial diminuindo a vitrificação e aumentando as concentrações de nitrato nos tecidos (Brand, 1993). O estado físico do meio de cultura pode afetar a difusão de nutrientes e reguladores de crescimento (Bornman \& Vogelmann, 1984) e o tipo de agente geleificante pode modificar a disponibilidade de substâncias solúveis através de interações químicas (Brand, 1993). Géis formados com agente geleificante sulfatado apresentam propriedades reológicas diferentes de não sulfatados. Desta forma pode-se esperar que concentrações variáveis de sais, assim como impurezas no agente geleificante, tenham grande influência na habilidade de regeneração. De um modo geral o meio de cultura deve ser firme o bastante para suportar os explantes, porém não muito rígido, pois pode prejudicar o adequado contato entre o meio de cultura e os tecidos. A disponibilidade de sais minerais presentes no meio de cultura geleificado também é afetada pela natureza do agente geleificante e pode explicar diferentes respostas nos cultivos in vitro.

Os sais minerais presentes como impurezas nos diferentes agentes geleificantes são quantitativamente e qualitativamente muito diferentes (Scholten \& Pierik, 1998a). Além disto, a geleificação com gellan envolve íons de $\mathrm{Ca}^{2+}$, afetando assim a disponibilidade de íons de $\mathrm{Ca}^{2+}$ no meio de cultura depois da solidificação. $\mathrm{O}$ efeito inibitório dos antibióticos aminoglicosídicos como a canamicina são afetados pela concentração de cálcio no meio de cultura. Com o aumento da concentração de cálcio 
no meio de cultura (1 para $10 \mathrm{mM}$ ) o efeito da canamicina é drasticamente reduzido (Joersbo \& Okkels, 1996). Assim, pode ocorrer interação entre os antibióticos aminoglicosídicos e os diferentes tipos de agente geleificante (Laine et al., 2000). Para produzir um efeito similar na eficiência de seleção, a concentração do agente seletivo deve ser adaptada à natureza do agente geleificante.

Berrios et al. (1999) estudando o efeito de diferentes agentes geleificantes (Phytagar - GibCo, Phytagel - Sigma, Arcagel - Sigma, Agar-agar - Fischer e agarose) na organogênese de girassol observou diferenças quanto à porcentagem de explantes formando brotos e número de brotos por explante. $\mathrm{O}$ melhor agente geleificante para os parâmetros estudados foi o Agar-agar - Fischer, seguido da agarose.

A qualidade do agente geleificante pode afetar, em princípio, todos os processos de desenvolvimento durante o cultivo in vitro, mas em especial, a formação de brotos adventícios e o enraizamento (Scholten \& Pierik, 1998b). O efeito é variável com a espécie, podendo ser menor em culturas bem adaptadas ao meio de cultivo. Barros et al. (1997), trabalhando com micropropagação de ápices meristemáticos de feijão da cultivar La Victoire, avaliaram o efeito de diferentes agentes geleificantes. Utilizaram Gelrite - Sigma, agarose, agar - Biomar e agar - Sigma. Observaram que a porcentagem de plantas sem crescimento e malformadas era maior no Gelrite - Sigma e na agarose. Somente o agar - Biomar e o agar - Sigma formaram plantas completas (aproximadamente 60 e $80 \%$ dos explantes formando plantas completas, respectivamente). A ausência de raízes e a formação de entrenó curto foram a principal causa da não formação de plantas completas, sendo o agente geleificante considerado fator limitante, principalmente ao enraizamento de plantas de feijão.

Kapaun et al. (1999) utilizando antibióticos aminoglicosídicos na seleção de brotos regenerados de Ulmus pumila L. observaram que em meio de cultura onde $\mathrm{o}$ Phytagel - Sigma era utilizado, como agente geleificante, os antibióticos neomicina e paromomicina precipitavam no meio, a menos que fosse utilizado agar como agente geleificante ou que a solução estoque de antibiótico fosse ajustada para $\mathrm{pH}$ acima de 9. A precipitação não foi afetada pela concentração de sais no meio. Todos os antibióticos aminoglicosídicos tendem a precipitar quando o agente geleificante utilizado é o Phytagel. 
Chauvin et al. (1999) comentam que, em um de seus trabalhos publicados anteriormente, o gladíolo era resistente a canamicina, mesmo em altas concentrações $\left(500 \mathrm{mg} \mathrm{L}^{-1}\right)$. Porém, seus estudos recentes demonstram que grande parte desta resistência deve-se à interação entre a canamicina e o agente geleificante utilizado (Danagel - Litex).

$\mathrm{Na}$ otimização do sistema de regeneração, a avaliação de diferentes agentes geleificantes deve ser incluída nos procedimentos para o desenvolvimento do protocolo, como observado por Scholten \& Pierik (1998), que trabalhando com 13 espécies de plantas, concluíram que a escolha do melhor agente geleificante para cada espécie e condição de cultura deve ser estudado em experimentos delineados com esta finalidade.

\subsection{Transformação genética}

A transformação genética caracteriza-se pela introdução controlada de ácidos nucléicos em um genoma receptor (Potrykus, 1991). Ao lado da hibridação somática, é uma das técnicas de transferência não sexuada de genes em plantas. Enquanto na hibridação somática os protoplastos de dois indivíduos se fundem, levando à mistura de genomas (Lindsey, 1992), a transformação é um processo mais controlado. Nele, apenas um fragmento definido de ácido desoxirribonucléico (DNA), que possui genes específicos, é introduzido no genoma do hospedeiro, ou genoma receptor, devendo ser a ele integrado.

Atualmente, graças aos progressos da biotecnologia, é possível introduzirse no genoma vegetal, características encontradas em outras plantas, animais, vírus ou bactérias. Para o feijão é de especial interesse a introdução de genes que melhorem características agronômicas como resistência às doenças e pragas, arquitetura e capacidade fotossintética da planta e valor nutricional dos grãos produzidos (Castro et al., 1987; Aragão et al., 1992).

O desenvolvimento da transformação genética tem possibilitado a quebra de barreiras como a incompatibilidade sexual existente entre indivíduos, possibilitando a transferência de genes entre organismos geneticamente distantes, ampliando assim 
consideravelmente, a formação de novas combinações que pelo método natural normalmente não ocorreriam. Permite, em um curto espaço de tempo, a introdução de genes de interesse em cultivares de alto valor comercial, eliminando com isso a necessidade de cruzamentos que em programas de melhoramento convencional podem durar anos.

O feijão, assim como outras leguminosas, apresentam inúmeras dificuldades para a transformação genética. Estas vão desde a cultura de tecidos, regeneração de plantas e transformação genética, até problemas de reprodutibilidade, aplicabilidade às demais variedades e baixa freqüência de transformação (Aragão et al., 1996; Nagl et al., 1997; Zambre et al., 2001).

O desenvolvimento de um sistema eficiente de transformação genética abre caminho para o melhoramento do feijão ao nível molecular, seja pela introdução de novos genes que possam corrigir falhas de cultivares elite, como a suscetibilidade a algumas doenças, seja pelo bloqueio de genes que expressem características indesejáveis, como fatores antinutricionais (Araujo et al., 1996; Birch, 1997).

\subsubsection{Transferência de DNA para o genoma da planta}

Existem diversos métodos de transferência de DNA para o genoma da planta, sendo que a escolha do melhor método depende da espécie a ser transformada, do tipo de material utilizado (calo, tecido, protoplasto, etc), da capacidade de regeneração da espécie, da disponibilidade de recursos, entre outros fatores. A transformação genética utiliza basicamente duas estratégias para realizar a transferência de DNA para plantas: a direta (métodos físicos) e a indireta (vetores biológicos) (Zambryski, 1992; Birch, 1997; Hansen \& Wright, 1999).

\section{Transferência direta de DNA}

Dentre os métodos de transferência direta de DNA pode-se mencionar a microinjeção (Neuhaus \& Spangenberg, 1990), a transformação de protoplastos por polietilenoglicol (Songstad et al., 1995) ou por eletroporação (Barros \& Carneiro, 1998) e o bombardeamento com microprojéteis (Klein et al., 1987). O objetivo comum de todos esses métodos consiste em quebrar-se a barreira da parede celular e da 
membrana plasmática para a livre penetração do DNA na célula. Nos métodos de transferência direta são utilizadas moléculas simples de DNA, que consistem de um módulo pequeno de expressão. Os módulos de expressão constituem-se de marcadores selecionáveis, os quais são clonados em plasmídeos com origem de replicação de Escherichia coli e gene marcador de resistência a determinado antibiótico, utilizado na seleção das bactérias que levam o inserto. Os vetores de transformação genética geralmente possuem um tamanho de 4 a $7 \mathrm{~Kb}$. Plasmídeos de maior tamanho geralmente apresentam menor estabilidade na transferência genética direta (Neuhaus \& Spangenberg, 1990; Potrykus, 1991; Vasil et al., 1991; Songstad et al., 1995; Aragão \& Rech, 1998; Barros \& Carneiro, 1998).

$\mathrm{Na}$ transferência direta de DNA o principal método é o bombardeamento com microprojéteis, o qual foi aperfeiçoado e denominado de biobalística (Sanford et al., 1993). A transformação por biobalística é uma técnica versátil, podendo ser utilizada para transformação de diferentes tipos de tecidos, órgãos e células, independente do genótipo. A transformação pode ser realizada em suspensões celulares, calos, embriões imaturos, partes de embriões maduros, meristemas, pedaços de folhas, pólen, micrósporo, etc. Espécies agronômicas consideradas recalcitrantes para a transferência de genes via Agrobacterium têm sido transformadas com o auxílio desta tecnologia. Este sistema utiliza gás hélio à alta pressão para aceleração de microprojéteis de um metal com alta densidade (ouro ou tungstênio), em forma esférica, com diâmetro de 0,2 a $4 \mu \mathrm{m}$ e velocidade de 300 a $600 \mathrm{~m} \mathrm{~s}^{-1}$; suficiente para penetrar as paredes e membranas celulares. Estes projéteis carregam moléculas de DNA precipitadas em sua superfície as quais são liberadas nos tecidos vegetais (Rech \& Aragão, 1998). Algumas moléculas de DNA atingem o núcleo da célula vegetal e, em menor freqüência, conseguem integrar-se de forma aleatória ao genoma. $O$ método de transferência direta utilizado não tem influência nos mecanismos de integração do DNA no cromossomo da planta. A natureza dos eventos de integração depende do DNA utilizado no bombardeamento e do organismo que está sendo transformado. Em plantas, a transferência direta ocorre pela integração do DNA através da recombinação não homóloga do fragmento introduzido, caracteristicamente com múltiplas cópias e algum grau de rearranjo cromossômico (Sanford, 1990). Desta forma ocorre a inserção de DNA em diferentes órgãos, tecidos e células, 
independentemente do genótipo usado (Klein et al., 1987; Sanford, 1990; Sanford et al., 1993; Rech \& Aragão, 1998).

As principais vantagens da biobalística são: a) transformação de tecidos, sem o uso de sistemas complexos de cultura de tecidos; b) transformação de células ou tecidos independentemente da variedade; c) o uso do cultivo in vitro é mínimo e; d) possibilidade de ajustar a aceleração das partículas causando poucos danos aos tecidos. Porém apresenta desvantagens como a necessidade de criteriosa avaliação para obtenção de progênies estáveis. É necessária a utilização de um gene marcador que possa ser facilmente detectado. Além disto, é uma metodologia patenteada e exige equipamentos específicos (Potrykus \& Spangenberg, 1995; Brasileiro \& Carneiro, 1998).

Em geral, com os métodos de transferência direta de DNA são obtidas quimeras dos genes introduzidos, resultantes da integração de cópias fragmentadas dos genes de interesse ou de múltiplas cópias, gerando silenciamento e instabilidade de expressão gênica, o que exige uma série de avaliações (Medford, 1992; De Block, 1993; Vergunst \& Hooykaas, 1999). Muitas vezes, a expressão do gene introduzido é instável, podendo declinar ou mesmo desaparecer durante o desenvolvimento da planta transgênica. Existe uma evidente interação entre os transgenes, onde as seqüências de DNA de uma inserção podem interferir na expressão do transgene de outra inserção. Assim, fenômenos como co-supressão, epistasia e silenciamento de genes podem ser freqüentemente observados. A co-supressão refere-se à inativação coordenada de dois transgenes em uma mesma célula, enquanto que na epistasia um transgene (o supressor) inativa um outro transgene. As interações epistáticas são irreversíveis em células somáticas, enquanto que a co-supressão mostra uma reversibilidade. A inativação do transgene pode acontecer a qualquer momento durante o ciclo de vida da planta (antes, durante ou depois da meiose). A idade da planta, o estresse ou a posição do transgene no genoma pode aumentar o fenômeno de silenciamento do gene. Existe uma grande correlação entre o silenciamento do gene e sua metilação (Brasileiro \& Dusi, 1998).

Plantas transgênicas estáveis de Phaseolus vulgaris foram obtidas a partir de embriões, inicialmente, utilizando-se um acelerador elétrico de partículas recobertas 
com DNA. A baixa taxa de obtenção de plantas transgênicas $(0,03 \%)$ é atribuída ao protocolo de regeneração, que além de demorado apresenta regeneração média de apenas dois brotos por explante (Russell et al., 1993). Plantas transgênicas estáveis também foram obtidas por outros pesquisadores, utilizando biobalística. Kim et al. (1996) obtiveram 6 plantas transformadas a partir de 319 embriões bombardeados (9\%), Aragão et al. (1996) obtiveram 27 plantas transgênicas a partir de 3079 embriões $(0,9 \%)$ e Aragão et al. (2002) obtiveram duas plantas tolerantes ao glufosinato de amônio, em 11607 eixos embrionários bombardeados $(0,02 \%)$, com perda de parte do plasmídeo em ambos os eventos.

\section{Transferência indireta de DNA}

$\mathrm{Na}$ transferência indireta utiliza-se um vetor biológico para promover a transferência do DNA desejado para a planta. Alguns vírus como caulimovírus e geminivírus, têm a capacidade de infectar e transferir DNA para o genoma de um amplo espectro de espécies vegetais, inclusive monocotiledôneas. Embora estes vírus não sejam utilizados rotineiramente como vetores de DNA para plantas, são de grande importância para o desenvolvimento da biologia molecular. Deles foram isolados seqüências importantes como o promotor constitutivo $35 \mathrm{~S}$ do vírus do mosaico da couve-flor (CaMV35S), de grande utilidade nas construções gênicas utilizadas em experimentos de transformação. O principal vetor usado na transferência indireta de DNA para o genoma vegetal é a Agrobacterium tumefaciens (Chilton et al., 1977).

\subsubsection{A Agrobacterium como vetor de transformação}

A transformação de plantas mediada por Agrobacterium tornou-se um dos métodos mais utilizados para a introdução de genes em células vegetais, capazes de regenerar plantas transgênicas, por ser um sistema simples, eficiente e barato (Firoozabady \& Kuehnle, 1995).

A Agrobacterium é uma bactéria gram negativa de solo, que vive em associação com plantas dicotiledôneas. É o único organismo conhecido com capacidade intrínseca de transferir DNA e proteínas para o citoplasma e núcleo de células vegetais e outros eucariotos, desde fungos até células humanas, tendo despertado interesse desde sua descoberta (Tzfira \& Citovsky, 2002). Este gênero de 
bactérias em sua forma selvagem hospeda vários tipos de plasmídeos e fagos. Os plasmídeos Ti (Tumor-inducing) e Ri (Root-inducing), de 120 a 250 kb, são exclusivos das espécies Agrobacterium tumefaciens e Agrobacterium rhizogenes, respectivamente, conferindo às mesmas a capacidade patogênica de alterar o metabolismo e o desenvolvimento das células da planta, que resulta na doença conhecida como "galha-da-coroa" no caso de Agrobacterium tumefaciens e síndrome das raízes em cabeleira, no caso de Agrobacterium rhizogenes. Este processo de colonização da planta requer a transferência de genes dos plasmídeos para o genoma da planta, que por sua vez, representa um mecanismo de engenharia genética natural de transferência de genes entre reinos diferentes. A proliferação dos tecidos que formam os tumores induz a síntese de opinas (aminoácidos e açúcares) pela bactéria, as quais são utilizadas como fonte de carbono e nitrogênio (Chilton et al., 1977; Ream, 1989; Riva et al., 1998; Hellens et al., 2000).

A demonstração, por Chilton et al. (1977), de que a causa da proliferação celular do tumor é a transferência de informação genética da bactéria para a célula vegetal foi o ponto de partida na utilização desse sistema natural de transferência de genes para plantas.

O mecanismo celular que permite a infecção por Agrobacterium e transformação da planta, foi revisto amplamente por muitos autores (Zambryski, 1992; Juliano \& Haskill, 1993; Weising \& Kahl, 1996; Riva et al., 1998; Gelvin, 2000). O processo de transferência depende de duas regiões essenciais: o T-DNA, região do plasmídeo que é transferida e integrada ao núcleo da célula hospedeira, e a região vir, composta pelos genes que codificam proteínas essenciais à transferência. Durante a infecção, a bactéria entra em contato com os compostos fenólicos, liberados pela planta nos locais de ferimento, ativa os genes de virulência (virA, virB, virC, virD e virE) presentes no plasmídeo Ti. A proteína do gene virA, uma quinase transmembrana, quando em contato com compostos fenólicos liberados pela planta, ativa o produto do gene virG, um fator de transcrição, que por sua vez, ativa os outros genes de virulência (virB, virC, virD e virE). Compostos fenólicos como a acetoseringona participam ativamente na indução dos genes de virulência. Muitas destas proteínas estão diretamente envolvidas no processamento do T-DNA do plasmídeo Ti e na 
subseqüente transferência do T-DNA da bactéria para a célula vegetal (Stachel et al., 1985; Riva et al., 1998; Gelvin, 2000).

Após a indução dos genes de virulência, a fita simples contendo as bordas do T-DNA são cortadas por proteínas dos genes virD1 e virD2, desencadeando o aparecimento de fitas simples e lineares de DNA correspondentes ao T-DNA. Estas fitas associam-se às proteínas do gene virE, que conferem estabilidade ao processo por proteger o T-DNA do "ataque" de endonucleases e a proteínas VirD2 que se ligam covalentemente à extremidade 5' do T-DNA. Este complexo de proteínas-DNA é transferido para o citoplasma da célula vegetal, onde regiões de sinalização de direcionamento nuclear das proteínas VirE2 e VirD2 orientam o complexo aos poros nucleares. Uma vez que o complexo encontra-se no núcleo, a integração do T-DNA no genoma da planta envolve proteínas que participam do processo de reparo, recombinação e síntese de DNA, da planta. O sistema de integração do T-DNA não é completamente conhecido, entretanto a inserção parece ser ao acaso, havendo uma preferência por regiões transcricionalmente ativas (Koncz et al., 1992; Ohba et al., 1995; Riva et al., 1998; Gelvin, 2000).

O T-DNA da bactéria é delimitado por duas bordas, à direita e à esquerda, as quais são formadas por 25 pares de bases, conhecidas como "seqüências repetidas" essenciais para que a transferência ocorra. Entre as bordas direita e esquerda encontram-se os genes oncogênicos que induzem a formação de tumores e a biossíntese de opinas. Estes genes, de origem bacteriana, são funcionais apenas em células de plantas. A remoção dos genes oncogênicos do T-DNA não interfere na capacidade da bactéria de transferí-lo e integrá-lo no genoma da célula hospedeira; porém, inibe a formação de tumores. Raças de Agrobacterium que não apresentam plastídios $\mathrm{Ti}$ oncogênicos são conhecidas como desarmadas. Outro componente genético essencial à transferência do T-DNA é a região vir; podendo residir em plasmídeos separados (Hellens et al., 2000). A região vir possui um grupo de aproximadamente 35 genes que são responsáveis pelo processo que envolve, desde o reconhecimento do hospedeiro pelo patógeno, até a inserção do segmento de T-DNA no núcleo da célula hospedeira. 
A substituição dos genes da região central do T-DNA por genes de interesse permite desenvolver vetores de transferência gênica para uma ampla variedade de espécies dicotiledôneas, hospedeiras naturais dessa bactéria e também para espécies não hospedeiras naturais como as monocotiledôneas (Caplan et al., 1983; Riva et al., 1998; Hansen \& Wright, 1999).

Apesar da sua importância biológica e extensiva aplicação na transferência de DNA, muito pouco é conhecido a respeito dos eventos que acontecem nas células hospedeiras durante a transformação genética por Agrobacterium (Ditt et al., 2001).

\subsubsection{Vantagens do sistema de transformação via Agrobacterium}

O sistema de transformação via Agrobacterium tumefaciens é bastante atrativo, pois exige um custo mínimo em equipamentos e um protocolo relativamente simples, embora muitas espécies apresentem dificuldade de transformação, como as monocotiledôneas e muitas leguminosas (Godwin et al., 1992). Resulta da integração de um segmento de DNA preciso, definido pelas bordas direita e esquerda do T-DNA, além de apresentar outras vantagens como transferir segmentos relativamente grandes de DNA, introduzir poucas cópias deste segmento (em geral uma ou duas) e de integra-lo facilmente em regiões expressas do genoma da planta. Embora alguns trabalhos mostrem a integração de múltiplas cópias, transformantes contendo cópias únicas podem ser facilmente recuperados (De Block, 1993; Hansen \& Chilton, 1996; Gelvin, 2000). O menor número de cópias evita problemas como o silenciamento gênico, bastante comum em sistemas de transformação direta.

Quando se utiliza a estratégia de co-transformação para a introdução de múltiplos genes, a transformação direta resulta geralmente em integrações ligadas, enquanto que a transformação via Agrobacterium resulta tanto em integrações ligadas quanto não ligadas (De Block, 1993).

\subsubsection{Fatores que afetam o processo de infecção e a transferência do T-DNA}

As espécies vegetais diferem grandemente em sua suscetibilidade à infecção por Agrobacterium (Cleene \& Deley, 1976; Anderson \& Moore, 1979). Mesmo dentro de espécies, cultivares ou ecótipos pode haver diferentes níveis de 
suscetibilidade a tumorogênese por uma raça particular de Agrobacterium. Esta diferença tem sido observada em milho (Schläppi \& Hohn, 1992), leguminosas (Hood et al., 1987; Schroeder et al., 1993), aspen (Beneddra et al., 1996), curcubitaceas (Smarrelli et al., 1986), pinus (Bergmann \& Stomp, 1992), tomate (Van Rekel et al., 1993), arabidopsis (Nam et al., 1997), eucalipto (Mullins et al., 1997), feijão (Nagl et al., 1997) e outras espécies.

Embora algumas diferenças na freqüência de transformação possam ser atribuídas aos fatores ambientais e fisiológicos, a base genética da suscetibilidade à transformação por Agrobacterium tem sido claramente verificada em algumas espécies de plantas (Robbs et al., 1991; Schläppi \& Hohn, 1992; Figueira et al., 1999; Tzfira et al., 2002). Muitos trabalhos demonstram que vários tecidos, órgãos e células dentro de uma planta podem diferir em sua suscetibilidade à transformação por Agrobacterium (Robbs et al., 1991; Bailey et al., 1994; Mauro et al., 1995; Nam et al., 1997).

Ritchie et al. (1993), avaliando a expressão transitória do gene uidA, demonstraram que em milho a transformação ocorre em segmentos do mesofilo, originados da região meristemática intercalar. Análises histoquímicas de secções desta região indicam que a atividade da $\beta$-glucuronidase ocorre apenas no cilindro vascular. Alguma atividade enzimática também foi localizada na folha e no cotilédone, mas não no broto apical. Já Shen et al. (1993) observaram a expressão do gene uidA localiza-se apenas nas folhas e cotilédones de brotos de milho. Schläppi \& Hohn (1992) demonstraram que embriões de milho são competentes à transformação apenas quando começam a diferenciar-se. No caso de ervilha, Dekathen \& Jacobsen (1995) demonstraram que apenas células diferenciadas próximas do sistema vascular de cotilédone e regiões do epicótilo de Pisum sativum são susceptíveis à transformação por Agrobacterium. Em Arabidopsis apenas células diferenciadas do mesofilo da folha e do cotilédone são susceptíveis à transformação. Entretanto, no tecido da raiz as células competentes são encontradas no periciclo desdiferenciado, e têm como característica comum sua morfologia (são pequenas, isodiamétricas possuem núcleo proeminente e um citoplasma denso) (Sangwan et al., 1992).

O tipo de explante alvo a ser transformado também tem importância, principalmente em espécies que apresentam dificuldades de transformação, não só 
pela suscetibilidade à Agrobacterium, mas também pela capacidade de regeneração de plantas, a partir de células transformadas. O explante com potencial organogenético não corresponde necessariamente a um material transformável. Resultados obtidos em experimentos de transformação direta, utilizando-se cultura de células sincronizadas, indicaram que a divisão celular aumenta a freqüência de inserção do DNA, principalmente se no explante predominarem células diferenciadas na fase G1 do ciclo celular. Entretanto se a transformação ocorre durante a fase de desdiferenciação celular, existe o perigo do DNA integrar-se em regiões do cromossomo não expressas em alguns tipos de células ou em toda a planta. Os transformantes da fase $S$ (síntese de DNA) e M (Mitótica) tendem a ter maior número de cópias integradas. Na fase $\mathrm{S}$, são observados padrões complexos de integração e rearranjos, enquanto que na fase M os rearranjos são menos freqüentes (De Block, 1993; Tinland, 1996; Birch, 1997). Neste caso, calos, em pleno crescimento, que apresentam células em todas as fases do ciclo celular são explantes favoráveis à transformação via Agrobacterium. Na maioria dos casos em que leguminosas são transformadas com razoável freqüência, a obtenção de plantas envolve a fase de calo, como em Vicia narbonensis (Pickardt et al., 1991), Pisum sativum (Schroeder et al., 1993); (Grant et al., 1995) e Phaseolus acutifolius (Dillen et al., 1997). Segundo Zambre et al. (2001) as metodologias de transformação genética via Agrobacterium baseadas na regeneração de plantas a partir de calos transformados são a única maneira indicada para se obter plantas transgênicas estáveis no gênero Phaseolus.

A eficiência da transformação pode ser aumentada pelo uso de linhagens de Agrobacterium altamente virulentas que possuem genes vir constitutivos (Hansen et al., 1994), pela indução de ferimentos nos tecidos a serem transformados e pela adição de compostos fenólicos como a acetoseringona; os quais induzem a expressão dos genes vir. O ferimento é necessário ao processo de transformação mediada por Agrobacterium, pois resulta na produção de indutores do processo de transferência do T-DNA e, as bactérias são atraídas para a célula vegetal por quimiotactismo positivo em relação a esses indutores como: compostos fenólicos, açúcares e aminoácidos (Stachel et al., 1985; Riva et al., 1998; Zupan et al., 2000).

O método que provoca o ferimento pode ser uma simples injúria causada durante o preparo do explante (Horsch et al., 1985), o uso de seringas ou por métodos 
mais sofisticados como o bombardeamento com micropartículas (agrolística) (Bidney et al., 1992) ou o uso da sonicação (Trick \& Finer, 1997).

A agrolística (ou agrobiobalística) é uma variação da transformação por biobalística, a qual é associada à transformação via Agrobacterium. Nesse caso o bombardeamento é utilizado para provocar os microferimentos no tecido vegetal, que liberam compostos fenólicos e por sua vez, mobilizam a transferência do T-DNA para a célula hospedeira. A técnica tem a vantagem de aumentar a freqüência de transformantes, uma vez que os microferimentos não prejudicam a célula vegetal e são suficientes para a indução da transferência do T-DNA (Bidney et al., 1992; Brasileiro et al., 1996).

Outros fatores como tempo de co-cultivo, temperatura, explante, etc. também influenciam na capacidade e freqüência de transformação.

\subsubsection{Uso da sonicação na transformação genética via Agrobacterium}

O primeiro relato do uso de sonicação em plantas foi o de Lehmann em 1954, o qual expôs raízes de Allium cepa a uma freqüência de 0,8 a $1,0 \mathrm{MHz}$ de ultrasom. Após a sonicação observou a presença de desenvolvimento de pequenas zonas de destruição. A reação biológica foi revertida quando as raízes eram sonicadas em ambiente pressurizado, indicando que o dano era induzido por cavitação do gás intracelular encontrado nas células de plantas. Miller et al. (1974) registraram uma ruptura localizada na parede de células corticais, na zona de elongação de raízes primárias de Vicia faba, em resposta ao ultra-som. Acredita-se que o efeito do ultrasom possa ser provocado por cavitação acústica particularmente de baixa energia. Dois fenômenos de cavitação acústica foram descritos: A primeira cavitação é conhecida como transitória onde pequenas bolhas são formadas e oscilam seu tamanho até finalmente explodirem, gerando ondas de alta pressão e temperatura durante o estágio final do colapso. A alta pressão de onda que emana da bolha é capaz de causar efeitos mecânicos, destruindo ou machucando o material como células e macromoléculas. A segunda cavitação é conhecida como estável. Nela ocorrem rápidas oscilações no tamanho da bolha, causando um violento fluxo de fluido que rodeia a bolha em um processo conhecido como "micro streaming". A alta 
velocidade do fluxo de fluido que rodeia a bolha resulta em uma destruição mecânica do tecido da planta e de macromoléculas (Trick \& Finer, 1997; Santarém, 2000).

Zhang et al. (1991), através da sonicação de pequenos pedaços de folhas de tabaco (4 X $8 \mathrm{~mm}$ ) com DNA, obtiveram transformação estável. Trick \& Finer (1997) desenvolveram a metodologia de transformação denominada SAAT ("Sonicationassisted Agrobacterium- mediated transformation"), na qual o explante é sonicado por curto período de tempo na presença de Agrobacterium. A sonicação produz microferimentos, melhoraram a eficiência de transformação. O tempo de sonicação deve ser suficiente para obter-se a maior eficiência de transformação, com o mínimo de dano ao tecido. Estudos com microscopia eletrônica e de luz revelaram que o tratamento com SAAT produz pequenas e uniformes fissuras e canais por todo o tecido, permitindo um acesso fácil da Agrobacterium no processo de infecção de tecidos internos. Experimentos realizados por Trick \& Finer (1997) demonstram que o número de ferimentos aumenta com o tempo de duração do tratamento com SAAT.

As análises histológicas de tecidos tratados com SAAT revelaram uma grande colonização bacteriana em células do tecido epidermal e subepidermal. Em tecidos que não recebem tratamento com SAAT, pode-se observar a presença de células bacterianas apenas na superfície dos tecidos. O método SAAT melhora consideravelmente a eficiência de transformação transitória em diferentes tecidos de plantas incluindo folhas, cotilédones imaturos, embriões zigóticos e somáticos, raízes, caules, gemas apicais, plântulas e em suspensão de células embriogênicas (Trick \& Finer, 1997; Santarém et al., 1998; Santarém, 2000).

Trick \& Finer (1997) estudaram o efeito do tempo de sonicação na eficiência de transformação de várias espécies consideradas recalcitrantes. A expressão transitória da $\beta$-glucuronidase aumentou entre 100 e 1400 vezes, dependendo da espécie e do tempo de sonicação.

Em soja, o uso de Agrobacterium sem sonicação resulta em uma baixa expressão transitória da $\beta$-glucuronidase. Santarém et al. (1998) trabalhando com cotilédones imaturos de soja observaram que o uso de SAAT melhorou a eficiência de transformação transitória destes explantes, permitindo a recuperação de plantas 
transgênicas em explantes sonicados por 2 segundos. Trick \& Finer (1998) trabalhando com cultura de células embriogênicas em suspensão observaram que a expressão transitória da $\beta$-glucuronidase aumentou com o uso de SAAT, permitindo a recuperação de clones de células 6 a 8 semanas após a sonicação e inoculação com Agrobacterium.

\subsubsection{Eliminação da Agrobacterium}

Após o co-cultivo de ápices caulinares de feijão, Barros et al. (1997) utilizaram cefotaxima para controlar a Agrobacterium. Para evitar os efeitos nocivos causados pelo antibiótico, os explantes foram previamente desinfectados com hipoclorito de sódio $0,25 \%$ durante 10 minutos e o tempo de contato com esse antibiótico reduzido para cinco dias.

A infecção com Agrobacterium, em embriões imaturos de milho, avaliada pela frequência de expressão de uma sequência viral por Schläppi \& Hohn (1992) apresentou correlação inversa com o crescimento da Agrobacterium no meio de cultivo. Em $100 \%$ dos embriões colhidos aos 10 dias após a polinização houve crescimento da bactéria em volta do meio de cultura e nenhuma infecção dos embriões, enquanto que aos embriões colhidos aos 18 dias após a polinização não apresentaram nenhum crescimento da bactéria e a infecção dos embriões foi de $75 \%$. Isto ocorreu, provavelmente, devido à produção de substâncias bacteriotóxicas pelos embriões, a partir dos 10 dias da polinização.

\subsubsection{Avaliação da eficiência de transformação}

A forma mais conveniente de se avaliar a eficiência da transformação genética é pela contagem do número de células ou tecido que expressem um determinado gene repórter. $\mathrm{O}$ uso de genes marcadores que permitem diferenciar as células transgênicas, por observação visual, possibilita determinar variáveis associadas ao método de transformação genética, em experimentos pilotos. Um exemplo bastante conhecido é do gene uidA, que codifica a enzima $\beta$-glucuronidase (GUS), uma hidrolase de peso molecular de 68,2 kDa. Esse gene foi isolado de um operon de Escherichia coli e é amplamente utilizado como gene marcador em transformação de plantas (Jefferson et al., 1986). A ampla aceitação desse gene deve-se à simplicidade, 
rapidez e versatilidade do método de detecção da atividade enzimática e ao fato de que a maioria das plantas não apresenta atividade endógena significante. Além disso, a $\beta$-glucuronidase não requer cofator, é bastante estável, resistente a diversos solventes e ativa em uma ampla faixa de pH $(5,0$ a 9,0) (Tör et al., 1992). No plasmídeo, a região codante é interrompida por um intron de célula eucariótica. Organismos procarióticos não possuem mecanismos para remover o intron, logo a expressão dessa enzima, na Agrobacterium, é bloqueada. Em plantas transgênicas, que contêm este gene, o intron é removido eficientemente, possibilitando a expressão da enzima. Entretanto, esse método apresenta algumas limitações, pois os ensaios são geralmente destrutivos e algumas plantas ou tecidos, particularmente órgãos reprodutivos, apresentam atividade similar à $\beta$-glucuronidase. Entretanto, quando o gene está sob o controle de um promotor forte a atividade endógena normalmente é inferior à observada em plantas transgênicas (Plegt \& Bino, 1989; Hu et al., 1990; Hodal et al., 1992). A atividade GUS em tecidos não transgênicos ou falsos positivos, também pode ser decorrente da presença de contaminações de fungos ou bactérias (Tör et al., 1992).

A atividade da $\beta$-glucuronidase pode ser detectada através do ensaio histoquímico, fluorimétrico, ou espectrofotométrico (Lacorte, 1998). O ensaio histoquímico é um método qualitativo, baseado na clivagem do substrato 5-bromo-4cloro-3-indolyl $\beta$-D-glucuronídeo (X-Gluc) pela enzima $\beta$-glucuronidase (Jefferson et al., 1987). O produto desta reação, na presença de oxigênio, forma dímeros, resultando num precipitado insolúvel de cor azul. É uma técnica de avaliação rápida que permite determinar a eficiência do processo de transferência após o co-cultivo do explante com a Agrobacterium. A expressão GUS é considerada apenas como uma evidência de transformação, não sendo suficiente como prova definitiva da integração do gene uidA ao genoma da planta (Potrykus, 1991). Ainda assim, o ensaio da $\beta$-glucuronidase é extremamente utilizado na identificação de tecidos de plantas potencialmente transformáveis e, também como parâmetro em estudos de otimização das condições de transferência de genes (Tör et al., 1992). Em explantes inoculados com Agrobacterium a eficiência de transformação pode ser quantificada por meio de contagem das áreas dos tecidos que expressam GUS ou pelo número de pontos azuis, 
normalmente expressos em porcentagem (Jia et al., 1989; Novoa \& Coles, 1994). Pontos com expressão da $\beta$-glucuronidase freqüentemente cobrem áreas multicelulares, mas isto pode ser devido à difusão de produtos enzimáticos de uma única célula. Fato semelhante foi observado em investigações histoquímicas da atividade da $\beta$-glucuronidase em tecidos de milho por Shen et al. (1993).

\subsubsection{Seleção de tecidos e plantas transformadas}

As técnicas de transformação genética geralmente levam à transferência do DNA de interesse a poucas células. Assim, um pré-requisito essencial é um protocolo eficiente de regeneração aliado a um sistema de seleção que possibilite a recuperação de plantas a partir destas células (Potrykus \& Spangenberg, 1995). Rotineiramente são utilizados genes conhecidos como marcadores de seleção, originários de fungos, bactérias, insetos ou mesmo de vegetais. Esses genes marcadores de seleção produzem proteínas com atividades enzimáticas que conferem às células transformadas resistência a um determinado substrato, permitindo que cresçam. O gene marcador pode ser o próprio gene de interesse ou um que irá conferir resistência a antibióticos ou a herbicidas nas células transformadas (Schell et al., 1983; Sawahel, 1996). A forma mais comum de seleção dos tecidos transformados é a indireta, baseada em um gene adicional, o qual confere vantagem seletiva em condições específicas. Uma exceção é a resistência a herbicidas. Neste caso, pode-se selecionar diretamente as células, tecidos ou plantas transformadas a partir de genes de interesse agronômico.

A utilização concomitante de dois tipos de genes marcadores é comum. Normalmente utiliza-se os genes que conferem resistência a antibióticos ou a herbicidas, juntamente com genes, cujo produto da expressão pode ser detectado por técnicas de espectrofotometria ou por ensaios histoquímicos.

As técnicas mais conhecidas de transformação genética utilizam duas estratégias básicas para a inserção do gene marcador: A primeira é a integração de todos os genes de interesse em uma mesma construção gênica. A segunda é a cotransformação, que consiste em se trabalhar com duas ou mais construções gênicas diferentes em uma mesma transformação, sendo uma com o gene marcador como, por 
exemplo, a resistência a um antibiótico e, as demais com genes de interesse agronômico. Aragão et al. (1996) obtiveram taxa de co-transformação de 40 a 50\%, em feijão, utilizando a biobalística.

A seleção dos transformantes é dada pela adição de um agente seletivo ao meio de cultivo em concentração a ser definida, que proporcione uma vantagem seletiva às células que contêm o gene marcador, sobre as células que não o possuem. O agente seletivo não só deve assegurar a proliferação celular e o desenvolvimento de estruturas organizadas, como também, permitir a recuperação de plantas transgênicas (Wilmink \& Dons, 1993).

Os principais fatores a serem considerados na escolha de um determinado gene marcador são: i) a expressão do mesmo não deve interferir no metabolismo normal das células transformadas, ii) seu produto deve proteger, de modo efetivo, as células transformadas, das propriedades inibitórias de crescimento do agente seletivo, além de ter uma boa difusão nos tecidos, de forma a permitir uma distinção fenotípica clara entre as células transformadas e as não transformadas e, iii) a exposição do explante transgênico ao agente seletivo, não deve afetar seu subseqüente crescimento e regeneração em plantas inteiras e férteis (Potrykus \& Spangenberg, 1995).

Dentre os genes marcadores que conferem resistência a um determinado antibiótico ou herbicida, estão: a) aqueles que produzem uma enzima funcional que não é reconhecida pelo agente seletivo (por exemplo, o gene aroA, que confere resistência ao herbicida glifosato e tem sido utilizado com agente seletivo com sucesso na obtenção de plantas transgênicas (Wilmink \& Dons, 1993); b) aqueles que produzem um produto que permite a desintoxicação e eliminação do agente seletivo (por exemplo, genes de resistência aos antibióticos cloranfenicol, neomicina e higromicina e o herbicida glufosinato de amônio) (De Block et al., 1987). Na maioria dos casos, o gene codifica uma enzima que inativa o agente seletivo por acetilação (cloranfenicol-acetil transferase e fosfinotricina-acetil transferase) (Wilmink \& Dons, 1993) ou por transferência de grupos fosfatos. Um exemplo de transferência de grupos fosfato é o gene neo, que é amplamente usado como marcador de seleção na transformação de plantas (Fraley et al., 1983). O neo é responsável pela produção da enzima neomicina fosfotransferase II (NPTII). Nesse caso a enzima neomicina 
fosfotransferase inativa diferentes antibióticos do grupo dos aminoglicosídicos, pela fosforilação do radical $3^{\prime}-\mathrm{OH}$. Neste grupo estão incluídos os antibióticos canamicina, geneticina (G418), neomicina e paramomicina. A canamicina é o antibiótico mais freqüentemente utilizado para a seleção de plantas transgênicas com o gene neo (John \& Amasino, 1988).

Usualmente o agente seletivo é adicionado ao meio de cultura logo após o término do co-cultivo. No entanto, um intervalo de alguns dias entre o término do cocultivo e o uso de canamicina pode ser benéfico. Archiletti et al. (1995) mostraram que, em dois cultivares de Prunus amygdalus, sem canamicina nos primeiros seis dias duplicaram a freqüência de transformação. Em Vitis vinifera, a adição de canamicina ao meio de cultura seis semanas após o término do co-cultivo permitiu seleção, de forma que todos os brotos que regeneraram eram transgênicos (Scorza et al., 1995). Pode-se considerar que a presença de canamicina favorece a multiplicação de células transformadas na competição com células não transformadas, mesmo se permitir a regeneração de um grande número de falsos transformantes (Scorza et al., 1995). Em amendoim considerou-se que a inibição de crescimento pela canamicina era tão severa nos explantes inoculados com Agrobacterium como nos não inoculados, optando-se então pela não utilização do agente seletivo. Na seleção de transformantes utilizou-se $o$ ensaio histoquímico da $\beta$-glucuronidase em folíolos das plantas regeneradas (McKently et al., 1995). Em soja, a canamicina não foi eficiente quando adicionada ao meio de indução de brotos. No entanto, foi eficiente quando adicionada ao meio de enraizamento (Di et al., 1996). 


\section{REGENERAÇÃO DE PLANTAS DE Phaseolus vulgaris L. A PARTIR DE CALO}

\section{Resumo}

Visando a transformação de Phaseolus vulgaris via Agrobacterium foi estabelecido um sistema eficiente e reprodutível de regeneração de plantas a partir de calos induzidos na região de inserção do cotilédone com o eixo embrionário. $O$ meio basal utilizado é composto dos sais MS (1962) e das vitaminas B5. Na indução, desenvolvimento e proliferação do calo utilizou-se o forchlorfenuron (CPPU) em combinação com o ácido indolacético (AIA). Os explantes utilizados foram os cotilédones de sementes (linhagem Xan 159, CIAT), germinadas in vitro (5 $\mu \mathrm{M}$ de BAP). Na fase de indução de calo os explantes permaneceram em meio de cultura (2,5 $\mu \mathrm{M}$ de CPPU e 2,5 $\mu \mathrm{M}$ de AIA) por 21 dias, sendo os primeiros 7 dias no escuro. Após a indução, parte dos cotilédones (aproximadamente $4 \mathrm{~mm}$, da região de contato com o eixo embrionário) foram transferidas para meio de desenvolvimento e proliferação do calo $(0,25 \mu \mathrm{M}$ de CPPU e 0,125 $\mu \mathrm{M}$ de AIA), com repicagens a cada 30 dias. A indução de brotos foi obtida com o aumento do tempo de permanência do calo no meio de proliferação para 50 dias, na última repicagem e transferindo-se para meio de indução de brotos (10 $\mu \mathrm{M}$ de BAP e $10 \mu \mathrm{M}$ de nitrato de prata) por mais 30 dias. Os calos foram transferidos para meio de desenvolvimento de brotos $\left(10 \mu \mathrm{M}\right.$ de BAP, $3 \mu \mathrm{M} \mathrm{GA}_{3}$ e 10 $\mu \mathrm{M}$ de nitrato de prata) até atingirem aproximadamente $2 \mathrm{~cm}$. No enraizamento dos brotos utilizou-se o ácido naftalenoacético $(2 \mu \mathrm{M})$ por 30 dias. Os explantes enraizados foram transferidos para vasos e aclimatados em casa de vegetação. As plantas regeneradas produziram sementes férteis, não apresentando diferenças visuais em relação às plantas originais. Este protocolo de regeneração apresenta características ideais para sua utilização em sistemas de transformação de Phaseolus vulgaris via Agrobacterium. 


\section{PLANT REGENERATION OF Phaseolus vulgaris FROM CALLUS}

\section{Summary}

A reproducible and efficient system of plant regeneration from embryoderived callus was established with the aim of transform Phaseolus vulgaris via Agrobacterium. The basal culture medium used was Murashige and Skoog basal salts supplemented with B5 vitamins. The CPPU (forchlorfenuron, N-(2-Chloro-4-Pyridyl)-N'Phenylurea) in combination with the IAA (indole-3-acetic acid) was used for callus induction and growth. The explants used were the cotyledons of seeds (breeding line Xan 159, CIAT) germinated in vitro (5 $\mu \mathrm{M}$ of BA $\left(N^{6}\right.$-Benzyladenine $\left.)\right)$. For callus induction, the explants were kept in culture medium $(2,5 \mu \mathrm{M}$ of CPPU and 2,5 $\mu \mathrm{M}$ of IAA) for 21 days, in absence of light during the first 7 days. After induction the cotyledon's end was cut (approximately $4 \mathrm{~mm}$ of the area closed to the embryo axis) and transferred to proliferation medium supplemented with $0,25 \mu \mathrm{M}$ of CPPU and 0,125 $\mu \mathrm{M}$ of IAA, for callus development, for 30 days. The shoot induction was obtained after 50 days. After this period the shoots were transferred to medium supplemented with 10 $\mu \mathrm{M}$ of $\mathrm{BA}$ and $10 \mu \mathrm{M}$ of silver nitrate for further 30 days. The callus were then, transferred to shoot development medium (10 $\mu \mathrm{M}$ of $\mathrm{BA}, 3 \mu \mathrm{M} \mathrm{GA}$ (gibberellic acid) and $10 \mu \mathrm{M}$ of silver nitrate) until the shoots were $2 \mathrm{~cm}$ high, before transferred to rooting media containing $2 \mu \mathrm{M}$ of NAA (naphthalene acetic acid). After 30 days, the rooting explants were transferred for vessels and acclimated in greenhouse. The regenerated plants produced fertile seeds, without apparently phenotypic variability. This plant regeneration protocol worked well to be used in Agrobacterium-mediated transformation of Phaseolus vulgaris. 


\subsection{Introdução}

O gênero Phaseolus, assim como outras leguminosas, têm se mostrado recalcitrante à regeneração de plantas in vitro e principalmente à transformação via Agrobacterium (Nagl et al., 1997; Zambre et al., 2001). Embora várias combinações de hormônios, tipos de explantes e condições de cultura tenham sido avaliadas exaustivamente, na tentativa de se obter suspensões celulares e calos de Phaseolus vulgaris, não foi possível regenerar plantas, a partir de embrióides (Nagl et al., 1997).

A produção de brotos a partir de calos se restringe a poucos trabalhos. $\mathrm{O}$ primeiro trabalho foi o de Crocomo et al. (1976), que regeneraram duas plantas de cultura de calos em meio suplementado com reguladores de crescimento e um extrato aquoso de sementes de feijão. Outros dois trabalhos, que mostram a utilização de combinações de TDZ (citocinina do grupo das feniluréias) e AIA (ácido indolacético) também chegaram à obtenção de plantas. Mohamed et al. (1993) regeneram plantas a partir de calos primários induzidos em pedicelos de dois genótipos de Phaseolus vulgaris L. (Xan 159 e GN Tara) e; Zambre et al. (1998) regeneraram plantas a partir de calos induzidos na região de ligação do cotilédone com o eixo embrionário, no caso do genótipo Xan 159. Ambos os genótipos utilizados são provenientes de cruzamentos interespecíficos com Phaseolus acutifolius A. Gray. Provavelmente, há neste caso um fator genético herdado de $P$. acutifolius que favorece a regeneração de plantas a partir de calos (Mohamed et al., 1993b).

Os calos são estruturas com alto potencial de transformação, especialmente se comparados a meristemas, que são os únicos explantes que regeneram plantas in vitro, com facilidade, em feijão.

Um método efetivo e reprodutível de regeneração de plantas a partir de células ou tecidos é essencial em estudos de genética e melhoramento de plantas envolvendo a transferência de genes pela engenharia genética. A falta de um sistema eficiente e reprodutível para regeneração de feijão tem limitado as várias tentativas de transformação de Phaseolus vulgaris via Agrobacterium. 
Este trabalho mostra a eficácia da CPPU na indução e proliferação de calo derivado da região de inserção do cotilédone com o eixo embrionário e a obtenção de plantas regeneradas a partir destes calos

\subsection{Material e métodos}

\subsubsection{Material vegetal}

Nos experimentos descritos a seguir utilizou-se a linhagem de Phaseolus vulgaris Xan 159 (CIAT) do banco de germoplasma do CENA / USP, multiplicado em casa de vegetação. A escolha do material foi baseada na sua capacidade de formação de calos e em citações de trabalhos correlatos publicados.

\subsubsection{Meio de cultura}

O meio de cultura basal (BA) para os diferentes experimentos descritos a seguir contém os sais do meio MS (Murashige \& Skoog, 1962), as vitaminas do meio B5 (Gamborg et al., 1968) e myo-inositol $\left(100 \mathrm{mg} \mathrm{L}^{-1}\right)$. A concentração de sacarose no meio basal foi de $30 \mathrm{~g} \mathrm{~L}^{-1}$ para os meios de germinação e alongamento, $10 \mathrm{~g} \mathrm{~L}^{-1}$ para o meio de enraizamento e de $20 \mathrm{~g} \mathrm{~L}^{-1}$ para os demais meios de cultura. $\mathrm{O} \mathrm{pH}$ foi ajustado para $5,8 \mathrm{com} \mathrm{HCl}$ antes da adição do agente geleificante e da autoclavagem $\left(121^{\circ} \mathrm{C}\right.$ por $15 \mathrm{~min}$ ). As vitaminas e o AIA (ácido indolacético) foram esterilizados por filtragem (filtro com poro de $22 \mu$ ) e adicionados após a autoclavagem. Os demais reguladores de crescimento foram adicionados antes da autoclavagem, nas concentrações especificadas em cada experimento.

\subsubsection{Germinação das sementes}

As sementes foram imersas em etanol $70 \%$ durante 30 segundos, seguidas da esterilização em hipoclorito de sódio a $2 \%$, por 10 minutos. Após a esterilização as sementes passaram por 2 enxágües de 1 minuto e 4 enxágües de 5 minutos em água destilada estéril. Depois de enxaguadas, as sementes foram posicionadas, com o hilo para cima, em meio de cultura composto de meio basal (BA) acrescido de $5 \mu \mathrm{M}$ de BAP e $7 \mathrm{~g} \mathrm{~L}^{-1}$ de Agargum (Sigma A9915). Posicionou-se 10 a 15 sementes por placa de Petri $(90 \times 15 \mathrm{~mm})$ contendo $30 \mathrm{ml}$ de meio de cultura, mantidas a $24 \pm 2{ }^{\circ} \mathrm{C}$, sob 
fotoperíodo de 16 horas de luz $\left(50 \mu \mathrm{mol} \mathrm{m}^{-2} \mathrm{~s}^{-1}\right)$, até $\mathrm{o}$ início da emergência das radículas, ou seja 2 a 3 dias.

\subsubsection{Explantes}

Para indução de calos utilizou-se, inicialmente como explantes, as folhas primárias e os cotilédones de sementes maduras germinadas in vitro. Os explantes foram retirados com auxilio de bisturi, destacando-se os cotilédones do eixo embrionário e cortando-se o pecíolo das folhas primárias, com auxílio de lupa estereoscópica, em condições assépticas. Nos experimentos cujo explante era o calo utilizou-se somente cinco explantes por placa, distribuídos equidistantemente, totalizando 0,7 a 1,0 grama, em média.

\subsubsection{Indução de calo}

Os cotilédones de sementes germinadas in vitro, utilizados na indução de calos, permaneceram em meio BA acrescido de forchlorfenuron (CPPU) e ácido indolacético (AIA) nas seguintes combinações de CPPU+AIA: $(0+0,0),(0+1,5),(0+5,0)$, $(1+0,0),(1+1,0),(1+1,5),(2+0,0),(2+1,5),(2+2,0),(3+0,0),(3+1,5),(3+3,0),(5+0,0)$, $(5+1,5),(5+5,0),(10+0,0),(10+1,5)$ e $(10+10)$. Os explantes permaneceram nestas condições durante 21 dias ( 7 dias no escuro e 14 dias em fotoperíodo de 16 horas a 50 $\mu \mathrm{mol} \mathrm{m}^{-2} \mathrm{~s}^{-1}$ ). $\mathrm{O}$ experimento foi conduzido em blocos ao acaso, com seis repetições, sendo a placa de Petri tomada como a unidade experimental. O número de explantes formando calos, aos 45 dias após a germinação das sementes, foi obtido e expresso em porcentagem.

\subsubsection{Crescimento e multiplicação do calo}

Após a indução de calos nos cotilédones retirou-se, com auxílio de bisturi, a região de inserção ao eixo embrionário (aproximadamente $4 \mathrm{~mm}$ ), que foi transferida para meio de crescimento de calo, com parte da região de corte, submersa no meio de cultura. O meio de cultura foi renovado a cada 30 dias. O meio de crescimento de calos (CC) consiste de meio BA, acrescido de AIA $(0,125 \mu \mathrm{M})$, de CPPU $(0,250 \mu \mathrm{M})$, Sacarose (2\%) e de Agargum Sigma A9915 (8 g L-1) e foi definido em uma série de experimentos preliminares. 
Quatro experimentos foram realizados, com a finalidade de otimizar a eficiência de produção de calos, tanto em quantidade como em qualidade, para serem utilizados na transformação genética via Agrobacterium. Estes experimentos tomaram como base o meio de cultura $\mathrm{CC}$. O delineamento experimental utilizado foi o de blocos ao acaso, com o número de repetições variável conforme o experimento, considerando-se a placa de Petri contendo 5 calos como unidade experimental.

As avaliações foram realizadas após os calos permanecerem por 30 dias no respectivo meio de cultura. $O$ desempenho dos diferentes tratamentos foi avaliado com base em medidas de peso fresco do calo. Segundo Phillips et al. (1995), de uma maneira geral calos quando cultivados regularmente em meio solidificado com agente geleificante apresentam um padrão de crescimento com comportamento sigmoidal durante cada repicagem para novo meio de cultura. Este padrão de crescimento geralmente pode ser dividido em cinco fases: fase lag, onde as células adaptam-se ao meio de cultura e preparam-se para a divisão celular; fase exponencial, onde a razão de divisão celular é alta; fase linear; onde a divisão celular fica mais lenta, mas a expansão celular aumenta; fase de desaceleração, onde a razão de divisão celular e o alongamento diminuem e; fase estacionária, onde o número e o tamanho das células permanece constante. Tanto as fases de crescimento como seu comportamento podem ser monitorados por medidas de peso fresco, as quais são convenientes principalmente quando medidas não destrutivas são desejadas (Phillips et al., 1995).

\subsubsection{Agente geleificante}

Neste experimento foram avaliados seis agentes geleificantes (A - Phytagel Sigma (4 g L $^{-1}$ ), B - Gelrite Gellan Sigma G1910 (4 g L-1), C - Agargum Sigma A9915 $\left(8 \mathrm{~g} \mathrm{~L}^{-1}\right)$, D - Bacto Agar DifCo $214010\left(8 \mathrm{~g} \mathrm{~L}^{-1}\right)$, E - Agar Fischer A360-500 (8 $\left.\mathrm{g} \mathrm{L}^{-1}\right)$ e F-Agar Merck Powder DAB6 $\left.\left(8 \mathrm{~g} \mathrm{~L}^{-1}\right)\right)$. Foram utilizadas 52 repetições, onde se avaliou a produção de massa viva e de massa morta dos calos, expressa em gramas por placa de Petri. 


\subsubsection{Níveis de ácido indolacético (AIA)}

Neste experimento avaliou-se o efeito de seis níveis de AIA $(0 ; 0,125 ; 0,25$; 0,5; 1 e $2 \mu \mathrm{M}$ ) na produção de massa viva e de massa morta dos calos, expressa em gramas por placa de Petri. Foram utilizadas 28 repetições.

\subsubsection{Níveis de nitrato de prata $\left(\mathrm{AgNO}_{3}\right)$}

O efeito de dez níveis de nitrato de prata $(0 ; 0,1 ; 1 ; 4 ; 7 ; 10 ; 15 ; 20 ; 50$ e $100 \mu \mathrm{M}$ ) foi avaliado quanto à produção de massa viva e de massa morta dos calos, expressa em gramas por placa de Petri. Foram utilizadas 24 repetições.

\subsubsection{Níveis de intensidade luminosa}

Os efeitos de dois níveis de intensidade luminosa (2 e $50 \mu \mathrm{mol} \mathrm{m} \mathrm{m}^{-2} \mathrm{~s}^{-1}$ ) foram avaliados quanto à produção de massa viva e de massa morta dos calos, expressa em gramas por placa de Petri. Foram utilizadas 21 repetições.

\subsubsection{Indução de brotos a partir de calo}

\subsubsection{Tempo de repicagem}

Os efeitos do tempo de repicagem (25, 50 e 75 dias) e do nitrato de prata ( 0 e $10 \mu \mathrm{M}$ ), na indução de brotos em calos, foram avaliados em experimento com delineamento experimental de blocos ao acaso, em fatorial $3 \times 2$, com 11 repetições. A placa de Petri foi considerada como sendo a unidade experimental. $O$ efeito destes fatores foi avaliado quanto ao número de calos com brotos, expresso em porcentagem, produção total, produção de massa viva e produção de massa morta dos calos, expressa em gramas por placa.

\subsubsection{Níveis de nitrato de prata e de BAP}

Neste experimento avaliou-se os efeitos do nitrato de prata $(0$ e $10 \mu \mathrm{M})$ e do $\operatorname{BAP}(0,5,10,20,40$ e $80 \mu \mathrm{M})$ na brotação de calos de feijão. O delineamento experimental utilizado foi o de blocos ao acaso em fatorial $2 \times 6$, com 4 repetições. A placa de Petri foi considerada como sendo a unidade experimental. Utilizou-se 5 calos por placa de Petri, que permaneceram durante 30 dias neste meio de cultura, antes de serem transferidos (calo inteiro) para frascos de vidro de $200 \mathrm{ml}$, contendo 
aproximadamente $30 \mathrm{ml}$ de meio de alongamento de brotos. $\mathrm{O}$ meio de alongamento de brotos (AL) é composto de meio BA acrescido de BAP (10 $\mu \mathrm{M}), \mathrm{GA}_{3}(3 \mu \mathrm{M}), \mathrm{AgNO}_{3}$ $(10 \mu \mathrm{M})$ e sacarose (2\%). Neste caso, o meio de cultura foi renovado a cada 25 dias. A avaliação do número de calos com brotos ocorreu ao final dos 30 dias. À medida que os brotos atingiam aproximadamente $2 \mathrm{~cm}$ de comprimento eram transferidos para meio de enraizamento.

\subsubsection{Enraizamento e transplante de brotos regenerados}

Para esse experimento utilizou-se o meio de cultura BA com nitrato de prata $(10 \mu \mathrm{M})$, sacarose $\left(10 \mathrm{~g} \mathrm{~L}^{-1}\right)$ e Agargum $\left(8 \mathrm{~g} \mathrm{~L}^{-1}\right)$. Os tratamentos utilizados foram 0,5 123 e $4 \mu \mathrm{M}$ de ácido naphtaleno acético (ANA) e 0,4 0,8 1,6 3,3 e 6,6 $\mu \mathrm{M}$ de ácido indolbutírico (AIB). Incorporou-se também um tratamento testemunha, sem regulador de crescimento. Os brotos foram mantidos em frascos de $200 \mathrm{ml}$, contendo $30 \mathrm{ml}$ de meio de cultura, por 30 dias. Após este período, todos os explantes enraizados, independente do meio de cultura utilizado para indução de raízes, foram transferidos para meio basal com sacarose $\left(10 \mathrm{~g} \mathrm{~L}^{-1}\right)$. $\mathrm{O}$ número de explantes que enraizaram foi obtido ao final dos primeiros 30 dias.

Durante o procedimento de excisão dos brotos para o enraizamento destacou-se os mesmos, evitando o corte na base. Desta forma outros brotos menores vêm juntos. Este procedimento foi adotado inicialmente por facilidades de manejo do material, mas observou-se um melhor enraizamento destes, frente aos brotos que eram cortados. Já De Carvalho et al. (2000) separaram os explantes em pedaços contendo no máximo cinco brotos antes de transferi-los para o meio de alongamento, para diminuir a diversidade de tamanho e densidade; o que reduzia o enraizamento dos brotos da variedade Carioca produzidas a partir de camadas transversais de células.

\subsubsection{Aclimatação dos brotos enraizados e produção de sementes}

Os brotos com raízes foram transferidos para vasos de $800 \mathrm{ml}$, contendo uma mistura (1:1 v:v) de substrato e vermiculita e mantidos em casa de vegetação ( $25^{\circ} \mathrm{C}$ e $80 \%$ de umidade relativa). As raízes foram previamente lavadas para eliminar restos de meio de cultura. Durante a primeira semana os vasos foram mantidos à 
sombra e protegidos por um saco plástico, que foi sendo aberto aos poucos na parte superior, aclimatando as plantas de forma gradual às condições da casa de vegetação. A taxa de sobrevivência dos explantes com raízes foi de $50 \%$, os quais produziram plantas com desenvolvimento normal de vagens e sementes.

\subsubsection{Análise das plantas regeneradas in vitro}

Um total de 20 plantas da variedade Xan 159, derivadas de cultura de tecidos $\left(\mathrm{S}_{0}\right)$ foram cultivadas em casa de vegetação. As plantas produziram sementes por autofecundação $\left(R_{0}\right)$. Duas sementes $R_{0}$ de cada planta $S_{0}$ foram semeadas em vasos de 3 litros e mantidos sob as mesmas condições, em casa de vegetação. Para a análise de possíveis variantes as plantas $S_{1}$ foram comparadas visualmente com plantas testemunha durante seu desenvolvimento.

\subsubsection{Análise estatística}

O delineamento experimental utilizado foi $\mathrm{o}$ de blocos ao acaso. As diferenças foram avaliadas utilizando-se o protocolo GLM do SAS com o teste de separação de médias de Tukey-Kramer.

\subsection{Resultados e discussão}

\subsubsection{Indução de calo}

A formação de um calo com coloração verde e de aspecto granular, com capacidade organogenética, semelhante ao descrito por Zambre et al. (1998), ocorreu em todos os tratamentos com presença dos reguladores de crescimento CPPU e AIA (Figura 1). O número de explantes que formaram calos aumentou com a concentração de CPPU na fase de indução. Os valores, em porcentagem, observados nas respectivas concentrações molares de CPPU foram de 3\% $(0 \mu \mathrm{M}), 11 \%(1 \mu \mathrm{M}), 18 \%$ (2 $\mu \mathrm{M}), 20 \%(3 \mu \mathrm{M}), 22 \%(5 \mu \mathrm{M})$ e $41 \%(10 \mu \mathrm{M})$. Estes resultados mostram a importância do CPPU em altas concentrações, na fase de indução de calo. Entretanto, a continuidade do desenvolvimento do calo ocorreu em concentrações mais baixas $(0,25$ $\mu \mathrm{M})$. A formação de calos em tratamentos sem CPPU na fase de indução só ocorreu 
em presença de AIA. Porém, o CPPU após a fase de indução foi essencial para que os calos proliferassem.

Os calos induzidos em diferentes combinações de CPPU e AIA foram avaliados visualmente quanto à morfologia e também quanto a características de aspecto geral como o brilho e a coloração dos calos, atribuindo-lhes uma nota. Nas avaliações realizadas após 100 dias de cultura dos calos, não se observou diferença significativa.

A atuação do CPPU na indução de calo em feijão pode ser semelhante ao TDZ, que segundo Murch \& Saxena (2001) atua preservando o IAA, elevando sua concentração nos tecidos e translocando-o a distâncias maiores dentro dos tecidos. Desta forma poderia estar controlando processos organogenéticos no calo de feijão; pois as auxinas representam uma das mais importantes classes de moléculas sinalizadores envolvidas na regulação, elongação e diferenciação celular das plantas superiores. 


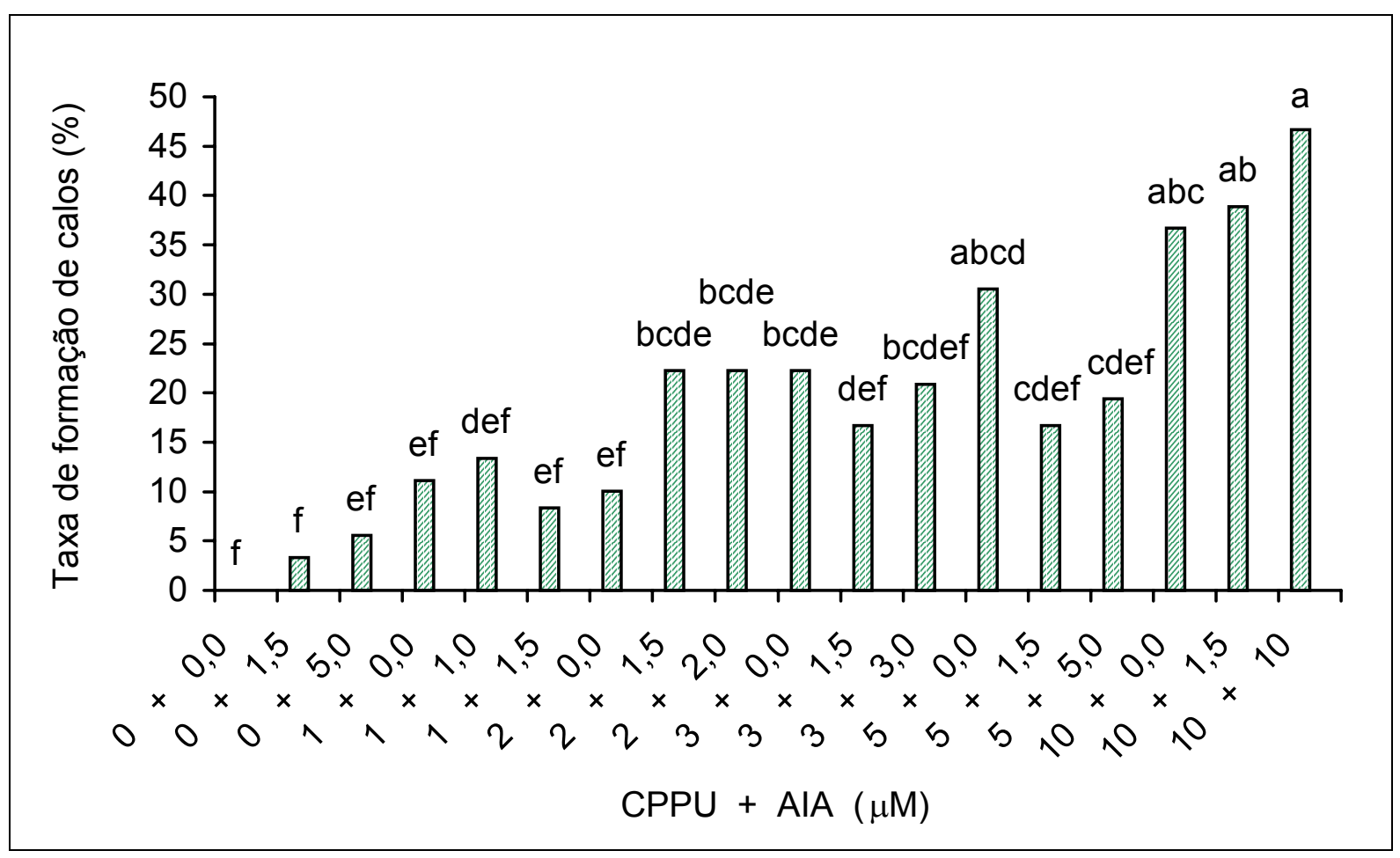

Figura 1. Taxa de formação de calos (\%) em diferentes concentrações de CPPU + AIA $(\mu \mathrm{M})$, aos 40 dias da germinação. Cada média é proveniente de 36 explantes. Médias não seguidas pela mesma letra diferem pelo teste $t$ de Student's, PDIFF $(p<0,05)$.

\subsubsection{Crescimento e multiplicação do calo}

O meio CC foi desenvolvido em uma série de experimentos preliminares onde se observou que a presença de CPPU é essencial para que o calo prolifere. A retirada do CPPU do meio de cultura inibe por completo o desenvolvimento do calo, iniciando com o escurecimento dos tecidos verdes e morte dos calos antes de completar 60 dias. Quando concentrações mais elevadas de CPPU (2,5 $\mu \mathrm{M})$ foram utilizadas os calos desenvolveram, porém a proporção de massa morta subiu consideravelmente.

Uma vez estabelecido o meio $\mathrm{CC}$ vários experimentos foram realizados para estudar-se o efeito de componentes específicos bem como a adição de outros, para otimização do método de desenvolvimento de calos, em meio de cultura. 


\subsubsection{Agente geleificante}

Pelos resultados da avaliação do efeito dos diferentes agentes geleificantes observa-se que há interferência dos mesmos na produção de calos em meio CC (Figuras 2 e 3). $\mathrm{O}$ agente geleificante pode interferir na habilidade do meio de cultura em induzir a resposta desejada no cultivo in vitro, como a formação de brotos e o enraizamento (Hadeler et al., 1995). Pode modificar a disponibilidade de substâncias solúveis através de interações químicas (Brand, 1993). A produção total de massa de calos nos agentes geleificantes do tipo gellan (Tratamentos $A$ e $B$ ) foi superior a dos agentes geleificantes do tipo agar, porém não diferiu significativamente pelo teste de Tukey-Kramer $(p<0,05)$ do agar Agargum (Tratamento $C$ ). Além disso os agentes geleificantes do tipo gellan apresentaram menor proporção de tecido morto $(18 \%)$ do que os agentes geleificantes do tipo agar (61\%). Esta redução na produção total de massa e aumento da proporção de tecido morto nos calos crescidos em agentes geleificantes do tipo agar, sugere que há um efeito inibitório, que além de impedir o desenvolvimento dos tecidos, também aumenta a proporção de tecido morto. Estes efeitos podem ocorrer devido a componentes naturais do agar e/ou aditivos. Estes componentes naturais do agar e/ou aditivos podem ser modificados de forma a favorecer o desenvolvimento e reduzir a proporção de tecido morto dos calos, a exemplo do que acontece com o Agargum Sigma. Alguns tipos comerciais de agente geleificante podem inibir a vitrificação por conter determinados componentes ou aditivos, que entretanto podem prejudicar a organogênese em alguns casos (Nairn et al., 1995). 


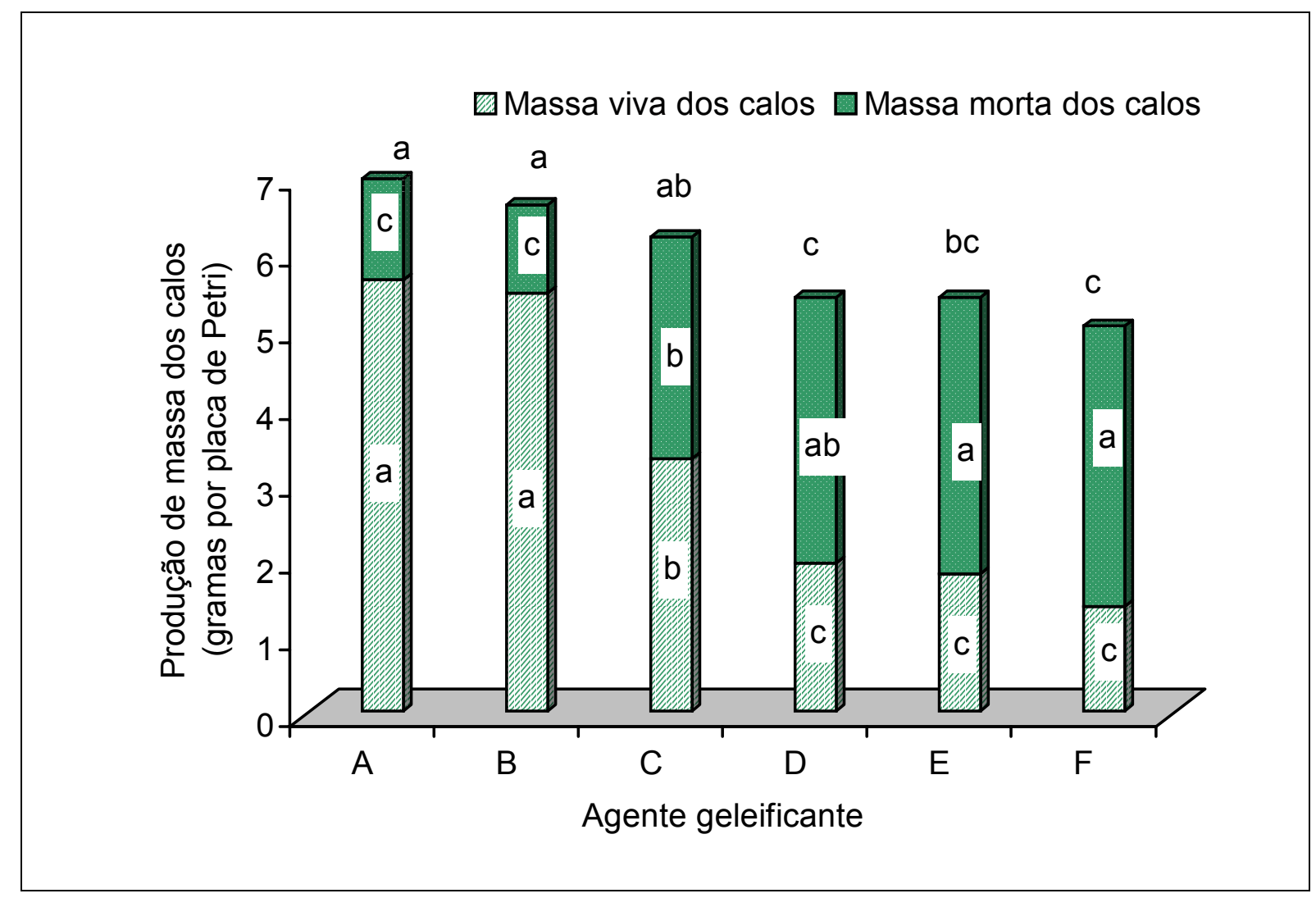

Figura 2. Efeito de seis agentes geleificantes (A - Phytagel $\left(4 \mathrm{~g} \mathrm{~L}^{-1}\right), B$ - Gelrite $(4 \mathrm{~g}$ $\left.\mathrm{L}^{-1}\right), \mathrm{C}$ - Agargum $\left(8 \mathrm{~g} \mathrm{~L}^{-1}\right), \mathrm{D}$ - Bacto Agar DifCo $\left(8 \mathrm{~g} \mathrm{~L}^{-1}\right), \mathrm{E}$ - Agar Fischer $\left(8 \mathrm{~g} \mathrm{~L}^{-1}\right)$ e $\mathrm{F}$ - Agar Merck $\left.\left(8 \mathrm{~g} \mathrm{~L}^{-1}\right)\right)$, na produção de calos de feijão (gramas por placa de Petri), após 30 dias em meio CC. Tratamentos com médias não seguidas pela mesma letra, diferem pelo teste de Tukey-Kramer $(p<0,05)$. Linha superior para produção total, linha intermediária para produção de massa morta e linha inferior para produção de massa viva dos calos.

\subsubsection{Níveis de ácido indolacético (AIA)}

As auxinas são uma das classes de reguladores de crescimento mais utilizadas em cultura de tecidos. Apresentam um papel importante em muitos aspectos do crescimento e do desenvolvimento das plantas, interagindo com as citocininas em processos de regulação da divisão celular (Frank \& Schmülling, 1999). 


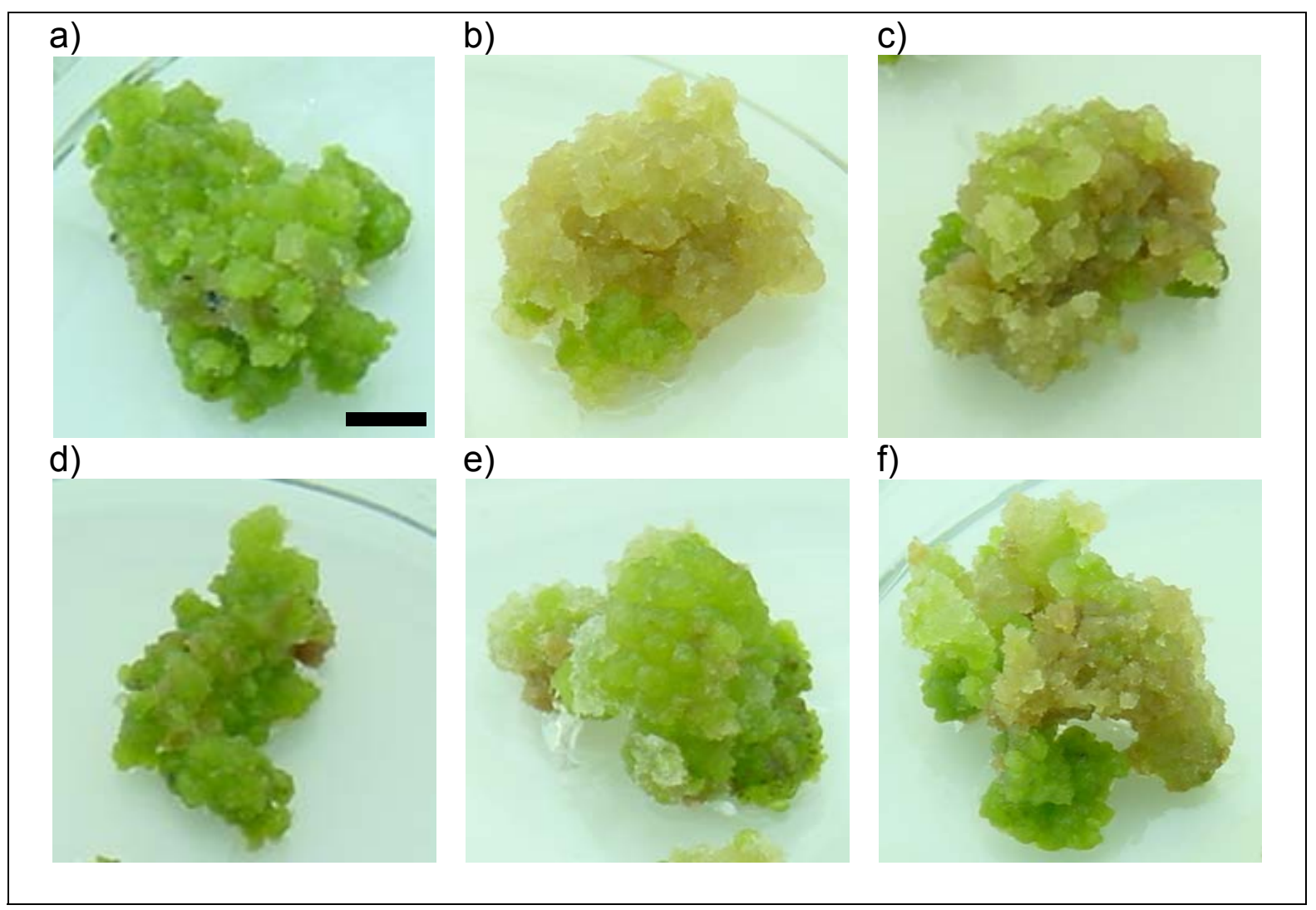

Figura 3. Efeito de seis agentes geleificantes: a) Phytagel Sigma $\left(4 \mathrm{~g} \mathrm{~L}^{-1}\right)$, b) Agar Merck (8 g L $\left.\left.{ }^{-1}\right), c\right)$ Bacto Agar DifCo $\left(8 \mathrm{~g} \mathrm{~L}^{-1}\right)$, d) Agargum Sigma $\left(8 \mathrm{~g} \mathrm{~L}^{-1}\right)$, e) Gelrite gellan Sigma ( $\left.4 \mathrm{~g} \mathrm{~L}^{-1}\right)$ e f) Agar Fischer $\left(8 \mathrm{~g} \mathrm{~L}^{-1}\right)$, no desenvolvimento de calos de feijão, após 30 dias em meio CC. Barra $=5 \mathrm{~mm}$.

Pelos resultados da avaliação do efeito dos diferentes níveis de AIA na produção de calos, em meio BA acrescido de $\operatorname{CPPU}(0,25 \mu \mathrm{M})$ e de Agargum $\left(8 \mathrm{~g} \mathrm{~L}^{-1}\right)$ observou-se diferenças na produção de massa de calos, provavelmente como reflexo de mudanças na taxa de divisão celular (Figura 4). No tratamento com 0,5 $\mu \mathrm{M}$ de AIA ocorreu a maior produção total de massa dos calos, entretanto não diferiu, pelo teste de Tukey-Kramer $(p<0,05)$, dos tratamentos com 0,125 e 0,25 $\mu \mathrm{M}$ de AIA. A produção de massa viva dos calos apresentou comportamento semelhante a produção total. A produção de massa morta dos calos não apresentou diferenças pelo teste de TukeyKramer $(p<0,05)$. Estes resultados evidenciam a atuação do AIA na divisão celular afetando o crescimento do calo sem alterar a taxa de morte celular. 


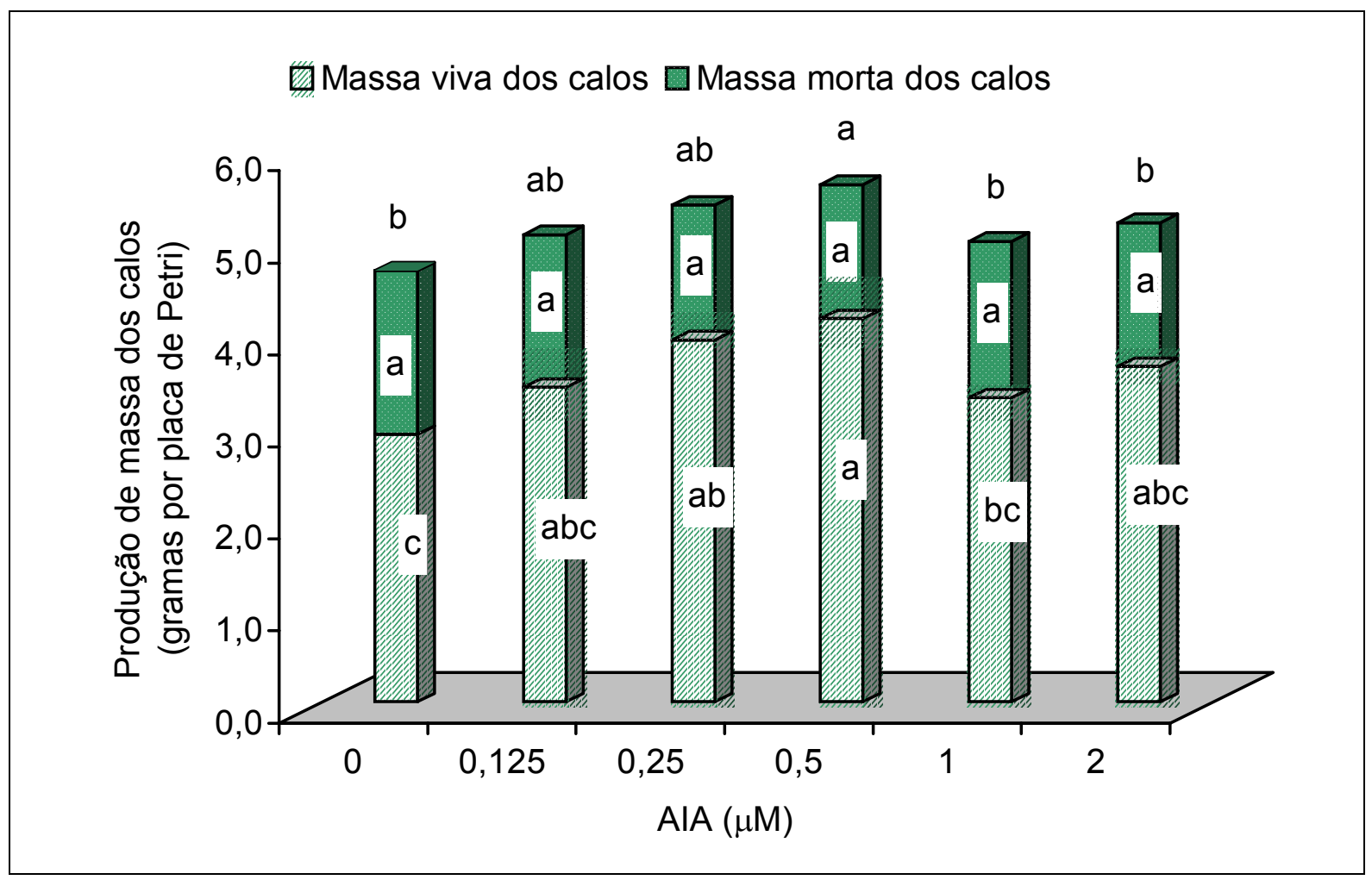

Figura 4. Efeito dos diferentes níveis de $\operatorname{AIA}(\mu \mathrm{M})$ na produção de calo de feijão (gramas por placa de Petri), aos 30 dias, em meio basal acrescido de CPPU $(0,250 \mu \mathrm{M})$ e Agargum $\left(8 \mathrm{~g} \mathrm{~L}^{-1}\right)$. Tratamentos com médias não seguidas pela mesma letra, diferem pelo teste de Tukey-Kramer $(p<0,05)$. Linha superior para produção total, linha intermediária para produção de massa morta e linha inferior para produção de massa viva dos calos.

\subsubsection{Níveis de nitrato de prata}

O etileno apresenta vários efeitos morfogenéticos no desenvolvimento das plantas. Dentre eles destaca-se a capacidade deste em promover a morte celular, através da atuação em elementos promotores presentes em genes que codificam: proteínas associadas ao amolecimento da parede celular (que ocorre durante o amadurecimento de frutos), enzimas hidrolíticas que dissolvem a parede celular durante a abscisão (como a abertura de órgãos para liberar sementes), proteínas induzidas por ferimentos em resposta a patógenos e proteinases que agem durante a senescência das folhas (Bleecker \& Kende, 2000). O nitrato de prata é um potente inibidor de etileno em plantas (Beyer, 1976) podendo evitar a morte de células em tecidos, que sob o cultivo in vitro apresentem produção de etileno elevada. 
O nitrato de prata apresentou efeitos positivos no controle da morte celular em calos de feijão desenvolvidos em meio de cultura CC (Figuras 5 e 6). A produção total de calos, nos diferentes níveis de nitrato de prata utilizados, não apresentou diferenças significativas pelo teste de Tukey-Kramer $(p<0,05)$. A produção de massa viva dos calos foi superior nos tratamentos com 7, 10 e $15 \mu \mathrm{M}$ de nitrato de prata, não diferindo significativamente pelo teste de Tukey-Kramer $(p<0,05)$ dos tratamentos com $4,20,50$ e $100 \mu \mathrm{M}$. A produção de massa morta dos calos do tratamento sem nitrato de prata foi superior aos demais tratamentos, não diferindo significativamente pelo teste de Tukey-Kramer $(p<0,05)$ do tratamento $0,1 \mu \mathrm{M}$. Os tratamentos com 7 e $10 \mu \mathrm{M}$ de nitrato de prata apresentaram a menor produção de massa morta dos calos, não diferindo significativamente pelo teste de Tukey-Kramer $(p<0,05)$ dos 4, 15, 20, 50 e $100 \mu \mathrm{M}$. Os dados da Figura 5 sugerem que o nitrato de prata, embora não interfira na taxa de desenvolvimento dos calos, pode diminuir a taxa de mortalidade de células e tecidos, durante os 30 dias que os calos permanecem em desenvolvimento no meio de cultura CC, acrescido deste.

O efeito do nitrato de prata é mais evidente quando se utiliza agentes geleificantes do tipo agar (dados não apresentados). Provavelmente o nitrato de prata funcione como um inibidor da ação do etileno, que pode estar sendo produzido durante o processo de desenvolvimento do calo, como resposta a substâncias presentes no agar. Quando se utiliza agentes geleificantes do tipo gellan, em especial o Phytagel, não há necessidade de utilização de nitrato de prata no meio de cultura $\mathrm{CC}$, pois o desenvolvimento dos calos nesse meio de cultura, acrescido ou não de nitrato de prata $(10 \mu \mathrm{M})$, é semelhante.

O Phytagel, de uma maneira geral, pode ser utilizado como agente geleificante no desenvolvimento de calos. Já para a indução de brotos nos calos, há necessidade de se utilizar o Agargum durante pelo menos 30 dias antes do início da indução, para que não vitrifiquem. 


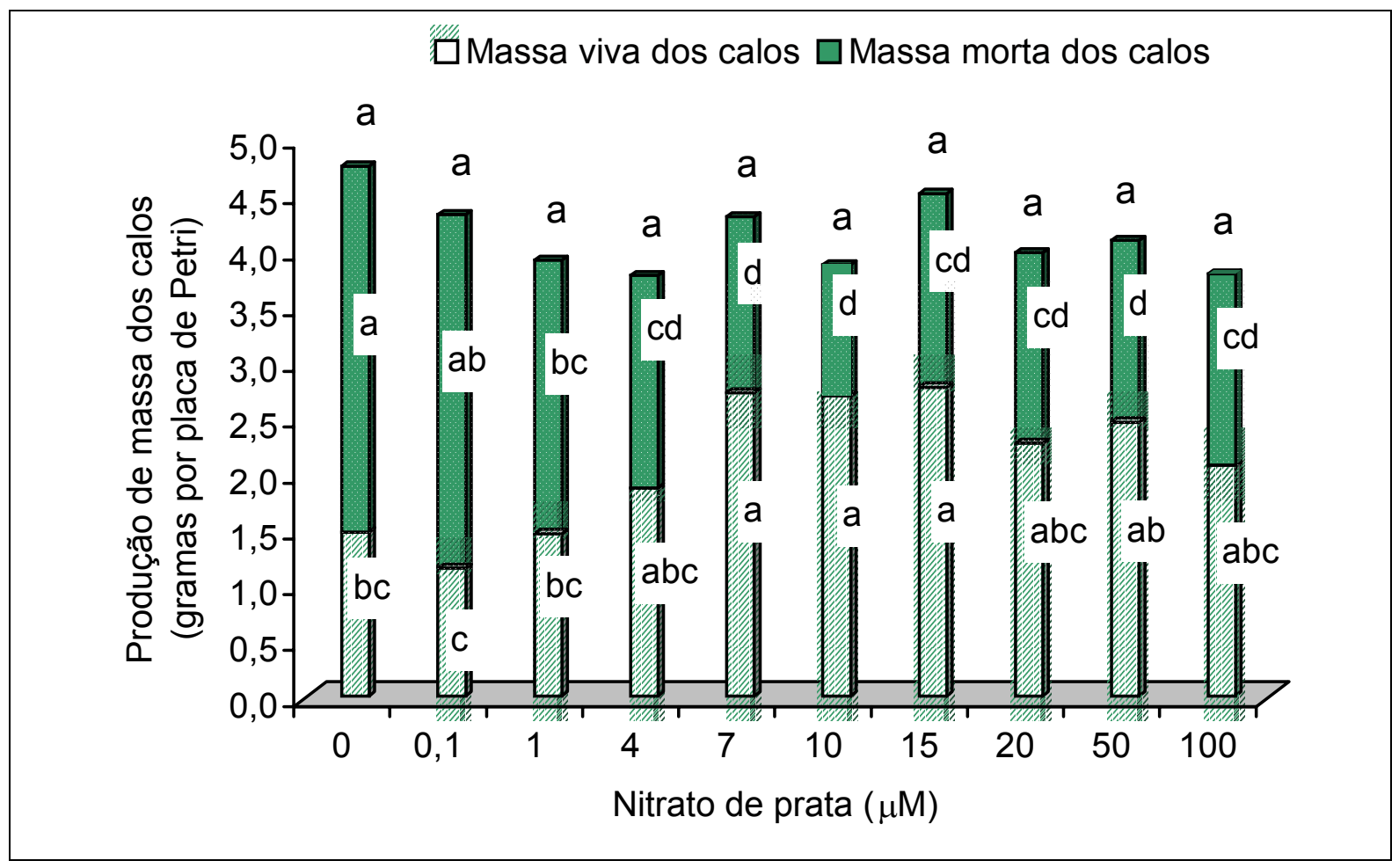

Figura 5. Efeito do nitrato de prata na produção de calo de feijão (gramas por placa de Petri), aos 30 dias em meio CC. Tratamentos com médias não seguidas pela mesma letra, diferem pelo teste de Tukey-Kramer $(p<0,05)$. Linha superior para produção total, linha intermediária para produção de massa morta e linha inferior para produção de massa viva dos calos.

a)

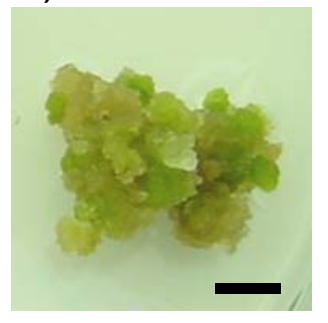

b)

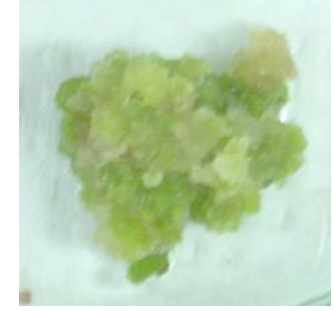

c)

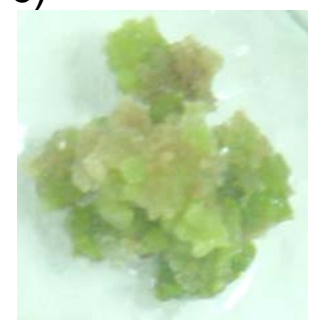

d)

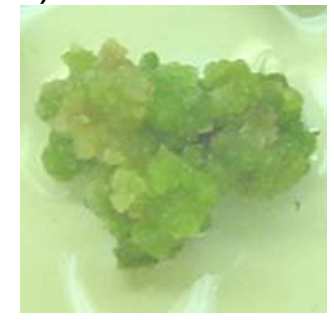

Figura 6. Efeito das diferentes concentrações de nitrato de prata: a) $0 \mu \mathrm{M}$, b) $7 \mu \mathrm{M}$, c) $10 \mu \mathrm{M}$ e f) $50 \mu \mathrm{M}$ de nitrato de prata, no crescimento dos calos. Barra $=5$ $\mathrm{mm}$. 


\subsubsection{Efeito da intensidade luminosa no crescimento de calos}

A intensidade luminosa interferiu com o crescimento dos calos de feijão em meio CC. Efeitos favoráveis foram observados em condições de maior luminosidade (Figura 7). A luz interfere no crescimento e desenvolvimento de culturas in vitro podendo ser indispensável em certos tipos de calos ou reprimir outros (Chakravarty \& Sopory, 1998; Liu et al., 2001; Hazra et al., 2002). Kosemura et al. (1997) identificaram a produção de uma substância inibidora de auxina, induzida pela luz, o indolylacetonitrile (IAN), resultante da degradação do composto 3indolylmethylglucosnolathe (IMG).

A produção total de calos e a produção de massa viva dos calos foram significativamente superiores pelo teste de Tukey-Kramer $(p<0,01)$ na intensidade luminosa de $50 \mu \mathrm{mol} \mathrm{m} \mathrm{m}^{-2} \mathrm{~s}^{-1}$, enquanto que a produção de massa morta dos calos foi superior na intensidade luminosa de $2 \mu \mathrm{mol} \mathrm{m}^{-2} \mathrm{~s}^{-1}$. O aumento da intensidade luminosa de 2 para $50 \mu \mathrm{mol} \mathrm{m}^{-2} \mathrm{~s}^{-1}$ resultou em um aumento de $24 \%$ da produção total de calos e a proporção de calos que permaneceu viva durante os 30 dias de cultura em meio CC passou de 35 para $72 \%$. Estas diferenças podem ser explicadas por diferentes respostas dos reguladores de crescimento e outros componentes do meio de cultura ao efeito da luz. Alguns podem ser fotolábeis ou; pela influência da luz na expressão de genes relacionados ao crescimento in vitro. Hangarter et al. (1991) observaram inibição do crescimento e da organogênese de tecidos de plantas cultivados in vitro causados pela luz, como resultado de mudanças fotoquímicas do meio de cultura.

A Figura 8 representa um cronograma do protocolo de indução e proliferação de calos de feijão, da linhagem Xan 159, onde são descritos os meios de cultura, tempo de cultivo e tipo de explante utilizado em cada fase. 


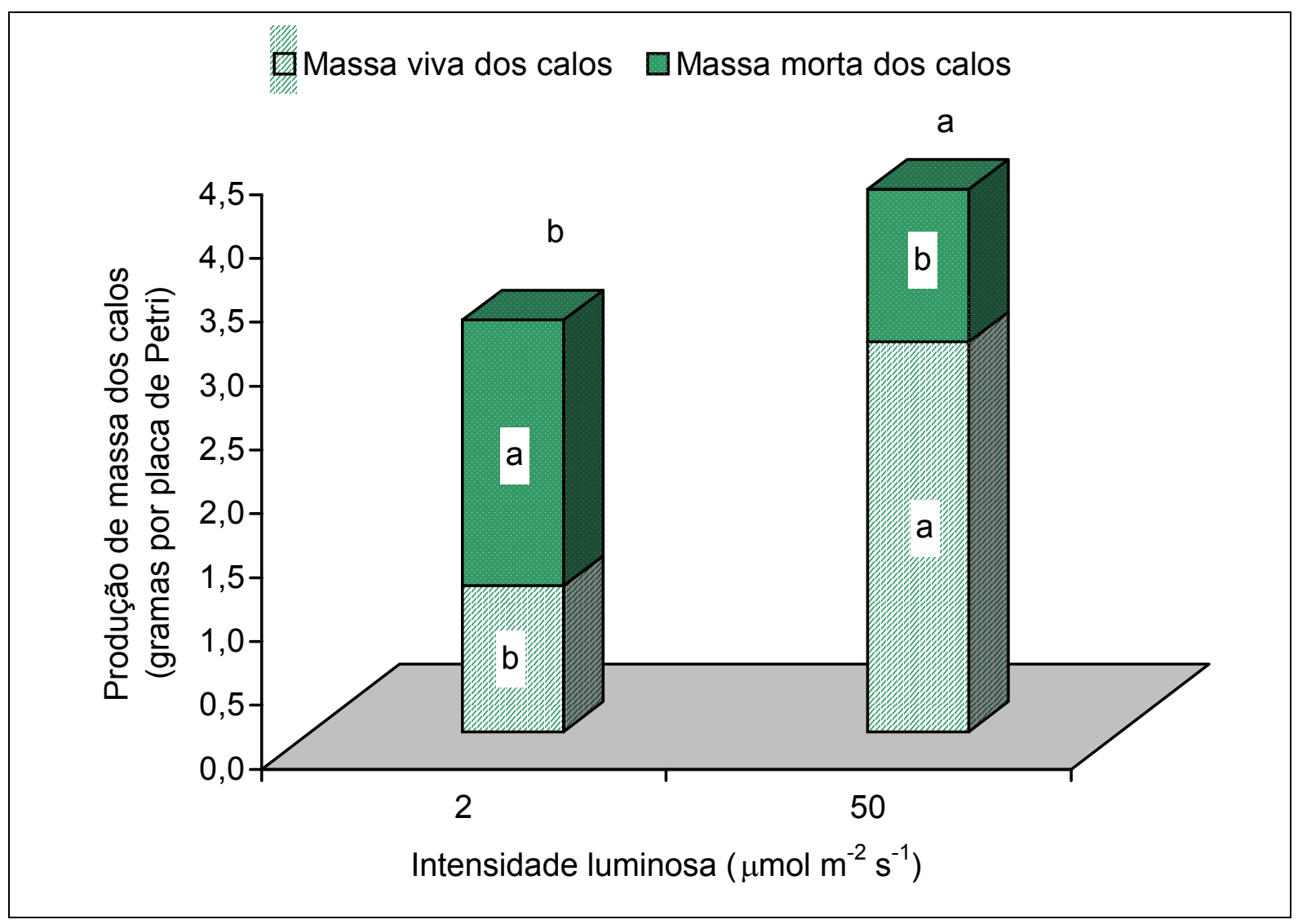

Figura 7. Produção de calo de feijão (gramas por placa de Petri), aos 30 dias em meio $\mathrm{CC}$, em duas intensidades luminosas (2 e $50 \mu \mathrm{mol} \mathrm{m} \mathrm{m}^{-2} \mathrm{~s}^{-1}$ ). Tratamentos com médias não seguidas pela mesma letra, linha superior para produção total, linha intermediária para produção de massa morta dos calos e linha inferior para produção de massa viva dos calos, diferem pelo teste de Tukey-Kramer $(p<0,01)$.

\subsubsection{Indução de brotos a partir dos calos}

O tempo de permanência dos explantes em meio de cultura e a dosagem de citocinina foram ajustados para que a taxa de indução de brotos a partir dos calos fosse alta. A formação de brotos por organogênese indireta é induzida em muitas espécies pela alta concentração de citocininas em relação às auxinas no meio de cultura, enquanto que em outras espécies pode ocorrer, mesmo na ausência de reguladores de crescimento (Phillips et al., 1995). Porém Zambre et al. (1998) trabalhando com feijão não conseguiram manter a capacidade de regeneração de plantas e brotação dos calos por mais do que 3 ou 4 meses, mesmo quando os calos foram mantidos em TDZ ou AIA/TDZ. 


\section{Dias}

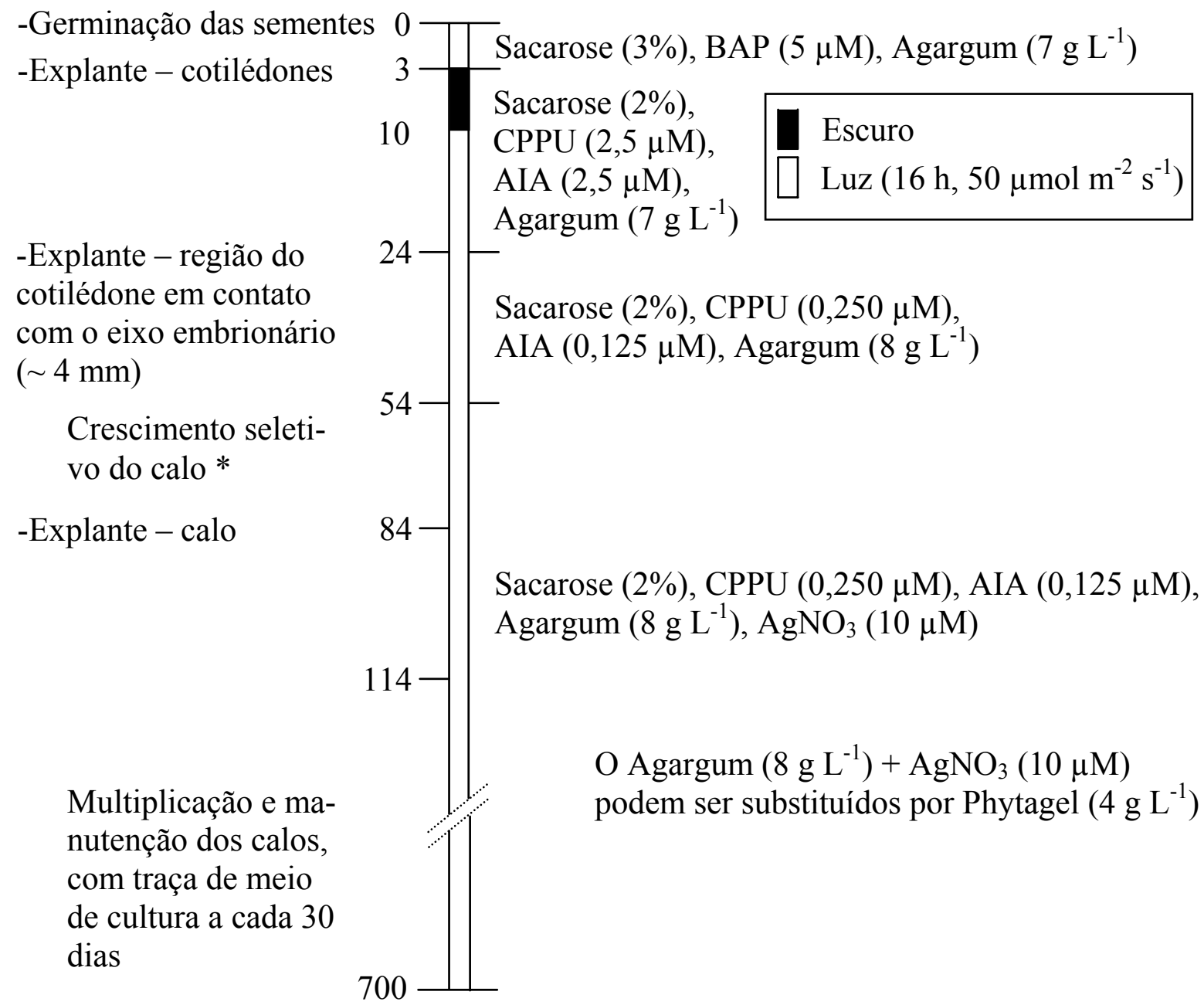

Figura 8. Cronograma do protocolo de indução e proliferação de calos de Phaseolus vulgaris linhagem Xan 159. Traços à esquerda referem-se às repicagens e traços à direita referem-se às alterações da composição do meio, tendo como referencia o meio basal (Sais e myo-inositol do meio MS e Vitaminas do meio B5). * Calos com coloração verde e aspecto granular.

\subsubsection{Tempo de repicagem}

O tempo de repicagem do explante juntamente com o efeito do nitrato de prata mostraram-se fatores importantes na formação de brotos em calos de feijão. Os resultados da Tabela 1 mostram os efeitos do tempo de repicagem e do nitrato de prata na taxa de calos de feijão brotando. A interação entre o efeito do tempo de repicagem e do nitrato de prata foi significativa pelo teste $F(p<0,0001)$. $O$ aumento da 
taxa de brotação dos calos com o tempo de permanência no meio de cultura CC foi maior em presença de nitrato de prata $(10 \mu \mathrm{M})$. Em média, os tratamentos que permaneceram 50 e 75 dias no meio de cultura com nitrato de prata $(10 \mu \mathrm{M})$ apresentaram uma taxa de brotação de calos duas vezes maior em relação aos tratamentos sem nitrato de prata.

Tabela 1. Taxa de brotação dos calos (\%), aos 25,50 ou 75 dias, em meio basal, acrescido de AIA $(0,125 \mu \mathrm{M})$, CPPU $(0,250 \mu \mathrm{M})$, Agargum $\left(8 \mathrm{~g} \mathrm{~L}^{-1}\right)$ e nitrato de prata, conforme os tratamentos.

\begin{tabular}{cccc}
\hline \multirow{2}{*}{$\begin{array}{c}\text { Tempo de } \\
\text { repicagem } \\
\text { (dias) }\end{array}$} & \multicolumn{2}{c}{ Nitrato de prata $(\mu \mathrm{M})$} & \\
\cline { 2 - 3 } & \multicolumn{2}{c}{$\begin{array}{c}\text { Média } \\
\text { Taxa de calos com brotos }(\%)\end{array}$} & \\
\hline 25 & $4 \mathrm{~b} \mathrm{~A}$ & $5 \mathrm{c} \mathrm{A}$ & 5 \\
50 & $24 \mathrm{a} \mathrm{B}$ & $43 \mathrm{~b} \mathrm{~A}$ & 34 \\
75 & $28 \mathrm{a} \mathrm{B}$ & $61 \mathrm{a} \mathrm{A}$ & 45 \\
Média & 18 & 37 & \\
\hline
\end{tabular}

* Médias não seguidas pela mesma letra, minúsculas na vertical e maiúsculas na horizontal, diferem pelo teste de Tukey-Kramer $(p<0,05)$.

A produção total de calos de feijão expressa em gramas de peso fresco por placa de Petri, aumentou com o tempo de permanência no meio de cultura de 25 para 50 dias e não apresentou diferenças significativas entre os tratamentos de 50 e 75 dias, independentemente da presença de nitrato de prata no meio de cultura (Tabela 2).

A produção de massa viva dos calos, também expressa em gramas por placa de Petri, foi maior no tratamento de 50 dias, com interação significativa, pois a taxa foi maior nos tratamentos de 25 para 50 dias, quando em presença de nitrato de prata (Tabela 3). 
Tabela 2. Produção total de calo de feijão (gramas por placa de Petri), aos 25, 50 e 75, em meio basal, acrescido de AIA $(0,125 \mu \mathrm{M})$, CPPU $(0,250 \mu \mathrm{M})$, Agargum $\left(8 \mathrm{~g} \mathrm{~L}^{-1}\right)$ e de nitrato de prata conforme o tratamento.

\begin{tabular}{cccc}
\hline \multirow{2}{*}{$\begin{array}{c}\text { Tempo de } \\
\text { repicagem }\end{array}$} & \multicolumn{2}{c}{ Nitrato de prata $(\mu \mathrm{M})$} & Média \\
\cline { 2 - 3 } (dias) & 0 & 10 & \\
\hline 25 & Produção total de calo (g por placa) & $5,2 \mathrm{~b}$ \\
50 & $5,9^{*}$ & 4,4 & $7,9 \mathrm{a}$ \\
75 & 9,8 & 7,0 & $8,5 \mathrm{a}$ \\
Média & 9,5 & 7,6 & \\
\hline
\end{tabular}

* Tratamentos com médias não seguidas pela mesma letra, minúsculas na vertical e maiúsculas na horizontal, diferem pelo teste de Tukey-Kramer $(p<0,05)$.

Tabela 3. Produção de massa viva dos calos de feijão (gramas por placa de Petri), aos 25, 50 e 75, em meio basal, acrescido de AIA (0,125 $\mu \mathrm{M})$, CPPU $(0,250 \mu \mathrm{M})$, Agargum $\left(8 \mathrm{~g} \mathrm{~L}^{-1}\right)$ e de nitrato de prata, conforme o tratamento.

\begin{tabular}{cccc}
\hline \multirow{2}{*}{$\begin{array}{c}\text { Tempo de } \\
\text { repicagem } \\
\text { (dias) }\end{array}$} & \multicolumn{2}{c}{$\begin{array}{c}\text { Nitrato de prata }(\mu \mathrm{M}) \\
\text { Produção de massa viva dos calos } \\
\text { (g por placa) }\end{array}$} & Média \\
\hline 25 & $3,2 \mathrm{~b} \mathrm{~A}^{*}$ & $3,4 \mathrm{~b} \mathrm{~A}$ & \\
50 & 4,3 a B & 5,5 a A & 3,3 \\
75 & 3,2 b B & 4,6 a A & 3,9 \\
Média & 3,6 & 4,5 & 3,9 \\
\hline * Médias não seguidas pela mesma letra, minúsculas na vertical e maiúsculas na \\
horizontal, diferem pelo teste de Tukey-Kramer $(p<0,05)$.
\end{tabular}

Nos tratamentos sem nitrato de prata houve aumento da produção de massa morta dos calos à medida que aumentou-se o tempo de permanência no meio de cultura CC (Tabela 4). Já para os tratamentos com nitrato de prata só ocorreu um aumento significativo na produção de massa morta dos calos de 50 para 75 dias. Nos tratamentos com nitrato de prata houve menor produção de massa morta dos calos em todos os tempos de repicagem.

Embora tenha havido aumento significativo da taxa de brotação de calos com o aumento do tempo de repicagem de 50 para 75 dias, a proporção de tecido vivo reduziu de 79 para $60 \%$. Como conseqüência ocorreu redução no potencial de 
produção de brotos por calo, tanto no que se refere à quantidade como à qualidade. Em resumo, o melhor resultado foi obtido aos 50 dias de cultivo em meio CC contendo $10 \mu \mathrm{M}$ de nitrato de prata.

\subsubsection{Efeito do BAP e do nitrato de prata}

Os resultados da Tabela 5 mostram os efeitos de diferentes níveis de BAP e de nitrato de prata na brotação de calos de feijão, em meio basal, após 30 dias. A interação entre o BAP e o nitrato de prata foi significativa pelo teste $F(p<0,05)$.

Tabela 4. Produção de massa morta dos calos de feijão (gramas por placa de Petri), aos 25, 50 e 75, em meio basal, acrescido de AIA $(0,125 \mu \mathrm{M}), \operatorname{CPPU}(0,250$ $\mu \mathrm{M})$, Agargum $\left(8 \mathrm{~g} \mathrm{~L}^{-1}\right)$ e de nitrato de prata, conforme os tratamentos.

\begin{tabular}{cccc}
\hline \multirow{2}{*}{$\begin{array}{c}\text { Tempo de } \\
\text { repicagem } \\
\text { (dias) }\end{array}$} & \multicolumn{2}{c}{$\begin{array}{c}\text { Nitrato de prata }(\mu \mathrm{M}) \\
\text { Produção de massa morta dos calos } \\
\text { (g por placa) }\end{array}$} & Média \\
\hline 25 & 2,7 c A * & $1,1 \mathrm{~b} \mathrm{~B}$ & \\
50 & $4,5 \mathrm{~b} \mathrm{~A}$ & $1,5 \mathrm{~b} \mathrm{~B}$ & 3,9 \\
75 & 6,3 a A & 3,0 a B & 4,6 \\
Média & 4,5 & 1,9 & \\
\hline * Médias não seguidas pela mesma letra, minúsculas na vertical e maiúsculas na \\
horizontal, diferem pelo teste de Tukey-Kramer $(p<0,05)$.
\end{tabular}

Tabela 5. Taxa de brotação dos calos (\%) aos 30 dias, em meio basal acrescido de BAP e de nitrato de prata, conforme os tratamentos.

\begin{tabular}{cccc}
\hline \multirow{2}{*}{ BAP $(\mu \mathrm{M})$} & \multicolumn{2}{c}{ Nitrato de prata $(\mu \mathrm{M})$} & Média \\
\cline { 2 - 3 } & \multicolumn{1}{c}{$\begin{array}{c}10 \\
\text { Taxa de calos com brotos }(\%)\end{array}$} & \\
\hline 0 & 15 a A * & 33 ab A & 24 \\
5 & 27 a A & 38 ab A & 32 \\
10 & 31 a B & 59 a A & 45 \\
20 & 37 a A & 42 ab A & 39 \\
40 & 42 a A & 34 ab A & 38 \\
80 & 40 a A & 16 b A B & 28 \\
Média & 32 & 37 & \\
\hline * Médias não seguidas pela mesma letra, minúsculas na vertical e maiúsculas na \\
horizontal, diferem pelo teste de Tukey-Kramer (p<0,05).
\end{tabular}


Os tratamentos contendo diferentes níveis de BAP, não diferiram significativamente pelo teste de Tukey-Kramer $(p<0,05)$, quando na ausência de nitrato de prata. Já os tratamentos com BAP, em presença de $10 \mu \mathrm{M}$ de nitrato de prata apresentaram diferenças significativas. $O$ tratamento com $10 \mu \mathrm{M}$ de BAP e $10 \mu \mathrm{M}$ nitrato de prata apresentou a maior taxa de brotação de calos, entretanto não diferiu significativamente pelo teste de Tukey-Kramer $(p<0,05)$ dos tratamentos com 0, 5, $20 \mathrm{e}$ $40 \mu \mathrm{M}$ de BAP. Os resultados mostraram um efeito sinérgistico entre o BAP e o nitrato de prata em dosagem equimolar $(10 \mu \mathrm{M})$, sendo considerado o melhor tratamento para indução de brotos em calos de feijão. Na Figura 9 pode-se observar calos de feijão após 30 dias em meio basal acrescido de nitrato de prata $(10 \mu \mathrm{M})$ e de BAP $(10 \mu \mathrm{M})$, seguidos por um período de 30 dias em meio de alongamento de brotos. Essa atuação positiva do BAP no desenvolvimento de brotos de feijão também foi observada no trabalho de Kartha et al. (1981) que regeneraram plantas de feijão a partir de multibrotações induzidas em meristemas apicais, e alongadas na presença de BAP (1 $\mu \mathrm{M})$, ANA $(0,1 \mu \mathrm{M})$ e $\mathrm{GA}_{3}(0,1 \mu \mathrm{M})$. Resultado semelhante foi obtido por Angelini \& Allavena (1989) que observaram um aumento na frequência de regeneração de brotos a partir de cotilédones imaturos de feijão, em meio de cultura contendo BAP.

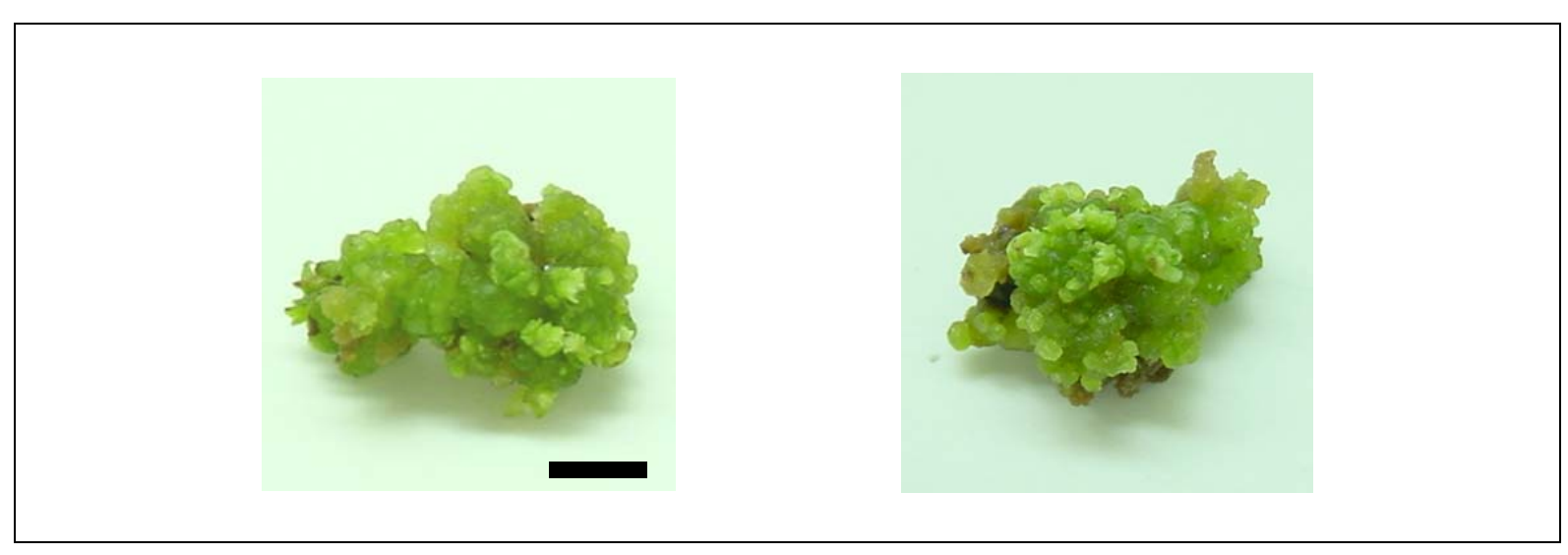

Figura 9. Calos com brotos, após 30 dias em meio basal (BA) acrescido de nitrato de prata $(10 \mu \mathrm{M})$ e BAP $(10 \mu \mathrm{M})$, seguido por um período de 30 dias em meio de alongamento de brotos (AL). Barra $=5 \mathrm{~mm}$.

A taxa de calos de feijão formando brotos respondeu positivamente ao aumento do tempo de permanência em meio de crescimento de calos de 25 para 50 dias e também ao aumento da concentração de BAP de 0 para $10 \mu \mathrm{M}$. 
Os calos induzidos e proliferados conforme descrito na Figura 8 mantiveram a capacidade de brotação, mesmo após dois anos de cultivo.

A indução de brotos ocorreu na ausência de CPPU, o que aumentou a proporção de massa morta dos calos. O nitrato de prata apresentou efeitos positivos nos dois experimentos de indução de brotos em calos de feijão; reduziu a proporção de massa morta dos calos submetidos às condições de indução de brotos, melhorando qualitativa e quantitativamente a produção das mesmas.

\subsubsection{Enraizamento e transplante de brotos regenerados}

Tanto o ANA como o AIB tiveram um efeito positivo no enraizamento de brotos originados de calos de feijão (Figura 10). O ANA foi mais efetivo na indução de raízes. O AIB parece não afetar o número de explantes enraizados a partir da concentração de $0,8 \mu \mathrm{M}$, atingindo um patamar de $30 \%$ de explantes enraizados. Já para o ANA há uma tendência de aumento da taxa de enraizamento com o aumento da concentração do mesmo, nas condições avaliadas. Nos tratamentos contendo uma concentração superior a 1,6 $\mu \mathrm{M}$ de AIB ou superior a $2 \mu \mathrm{M}$ de ANA as raízes formadas eram mais espessas, provavelmente devido ao longo tempo de permanência em contato com os reguladores de crescimento do meio de cultura. $O$ tratamento que se apresentou melhor quanto à taxa de enraizamento e também com relação ao aspecto das raízes, foi o contendo $2 \mu \mathrm{M}$ de ANA.

Pelos resultados observados podemos sugerir que a utilização de níveis mais elevados de ANA requer uma redução do tempo de contato deste regulador de crescimento com os explantes, pois se os explantes fossem mantidos em concentrações mais elevadas de ANA por um período menor, provavelmente os efeitos indesejáveis, como o aumento do diâmetro das raízes, poderiam ser minimizados. 


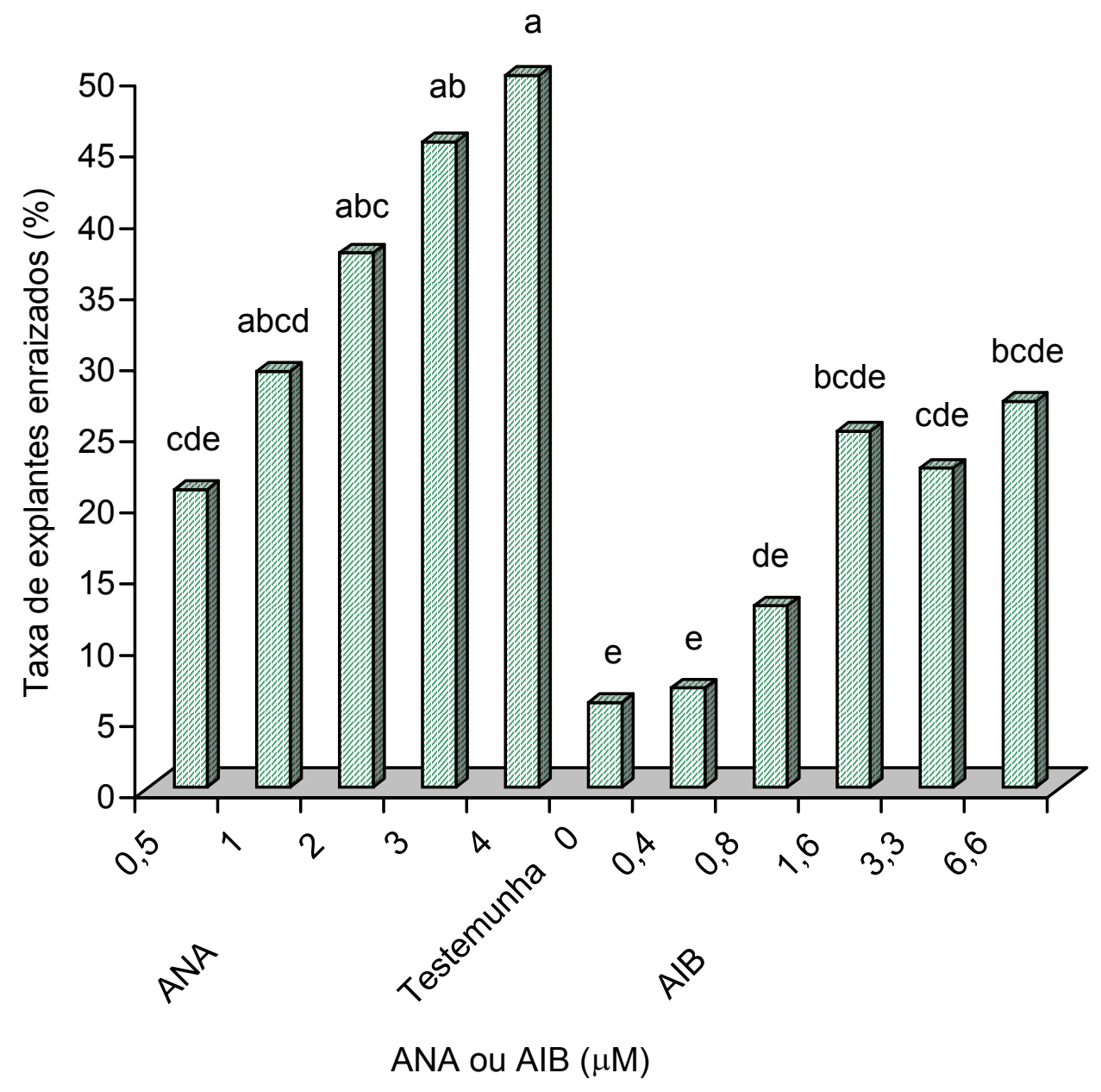

Figura 10. Taxa de enraizamento (\%) dos brotos provenientes de calos, após 30 dias em meio basal, com sacarose (1\%), acrescido de diferentes níveis de ANA. Tratamentos com média não seguida pela mesma letra diferem pelo teste de Tukey-Kramer $(p<0,05)$.

O enraizamento de plantas de feijão, regeneradas a partir de multibrotações induzidas por BAP $(10 \mu \mathrm{M})$ e alongadas por BAP $(1 \mu \mathrm{M})$, ANA $(0,1 \mu \mathrm{M})$ e $\mathrm{GA}_{3}(0,1 \mu \mathrm{M})$, foi obtido por Kartha et al. (1981) na presença de $1 \mu \mathrm{M}$ de AIA. Khalafalla et al. (2000) mostraram que inibidores de etileno, como o nitrato de prata, atuam no enraizamento de brotos de fava regenerados em presença de thidiazuron de várias formas: antecipando a formação e aumentando o número de raízes, bem como o crescimento dessas. Assim pode-se melhorar os protocolos de regeneração que utilizam feniluréias (Khalafalla \& Hattori, 2000). De Carvalho et al. (2000) observaram que brotos de Phaseolus vulgaris, provenientes da organogênese direta, formaram 
raízes na presença de ANA $(1 \mu \mathrm{M})$ e $\mathrm{AgNO}_{3}(10 \mu \mathrm{M})$, a uma taxa de $80 \%$. Esse resultado, mostra também a importância do nitrato de prata no enraizamento do Phaseolus vulgaris.

Após passarem pela indução de brotos e 60 dias em meio de alongamento (Figura 11a), os calos de feijão podem permanecer por mais uma ou duas repicagens no mesmo meio de cultura ou serem transferidos para meio de enraizamento (Figura 11b e 11c). Após 35 dias da aclimatação as plantas florescem e iniciam a formação de vagens (Figura 11d).

\subsubsection{Análise das plantas regeneradas in vitro}

Plantas regeneradas de calos podem mostrar variabilidade morfológica. A variabilidade pode ser temporária, ou seja, resultante das condições de cultura quando em presença de reguladores de crescimento. Pode estar relacionada a mutações genéticas espontâneas durante o cultivo in vitro ou a outros fatores (Phillips et al., 1995). Para a identificação de possíveis variantes faz-se necessária uma comparação visual entre as plantas cultivadas in vitro e as plantas originais. As plantas provenientes de sementes de plantas cultivadas in vitro $\left(S_{1}\right)$, mantidas em casa de vegetação, não apresentaram diferenças quando comparadas visualmente com as plantas originais, sob as mesmas condições. Análise semelhante realizada por Mohamed et al. (1993), em plantas de feijão $S_{1}$ regeneradas a partir de calos de pedicelo, mostraram diferenças quanto à estatura em algumas plantas. As plantas $S_{1}$ apresentaram cerca de $20 \mathrm{~cm}$ a mais em relação à média da linhagem original. 


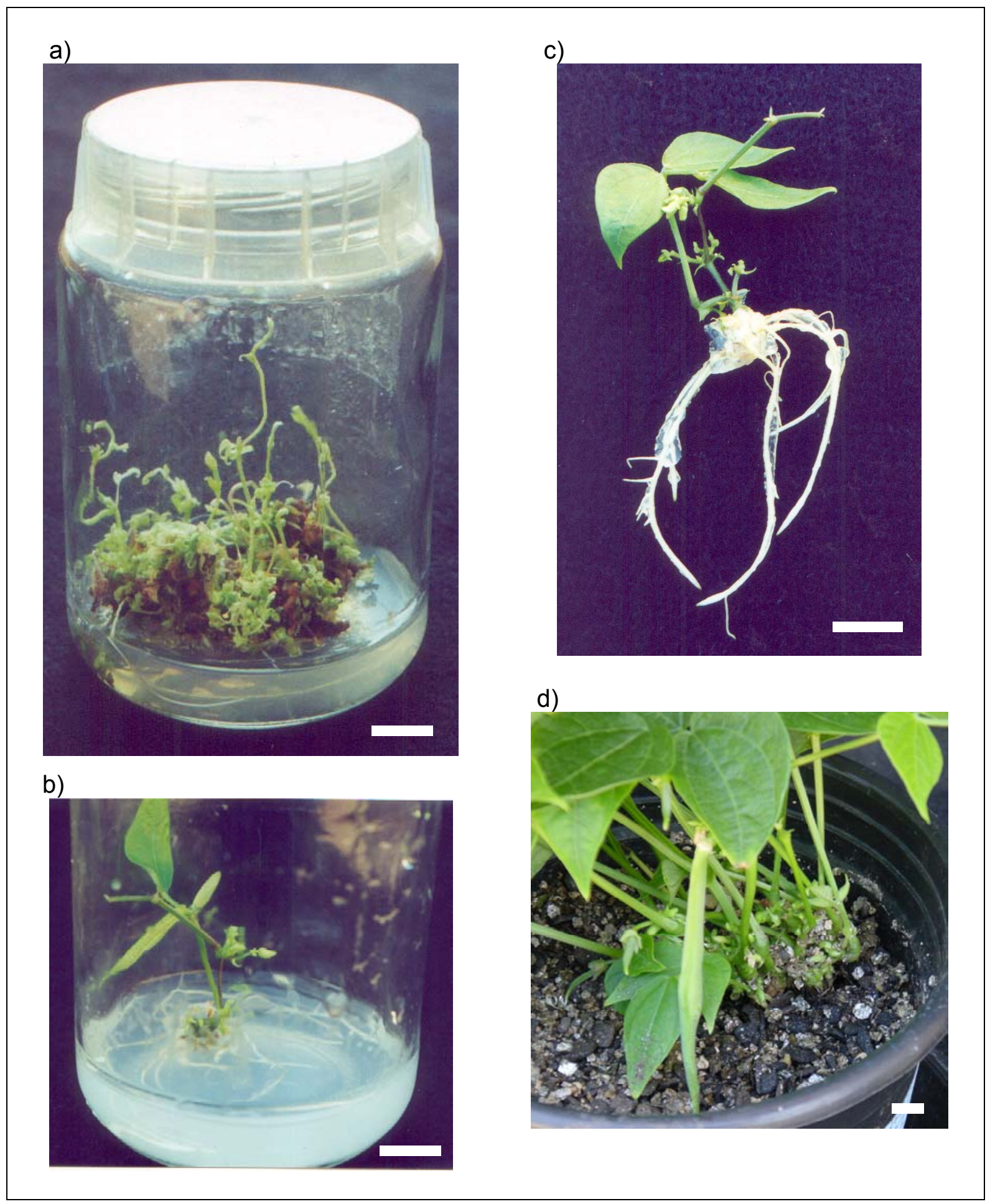

Figura 11. Regeneração de plantas de feijão a partir de calos. a) alongamento de brotos (AL) após 60 dias, b) e c) brotos enraizados, após 30 dias em meio de enraizamento com $2 \mu \mathrm{M}$ de ANA seguido de 30 dias em meio basal com $1 \%$ de sacarose, d) planta regenerada, 45 dias após o transplantio para vaso, em casa de vegetação. Barra $=10 \mathrm{~mm}$. 


\subsection{Conclusões}

Desenvolveu-se através da organogênese indireta um sistema de regeneração eficiente e reprodutível de plantas a partir de calos originados da região de inserção do cotilédone com o eixo embrionário, utilizando-se o CPPU. O método compreende as seguintes etapas: Indução, crescimento e multiplicação de calos, Indução de brotos a partir de calos e Desenvolvimento, alongamento e enraizamento dos brotos. Este protocolo mostrou-se bastante promissor para o desenvolvimento de uma metodologia eficiente de transformação de feijão, especialmente via Agrobacterium. 


\section{TRANSFORMAÇÃO DE CALO ORGANOGENÉTICO DE Phaseolus vulgaris L. VIA Agrobacterium}

\section{Resumo}

O feijão é uma espécie recalcitrante à transformação genética, especialmente via Agrobacterium, fazendo-se necessário estudos da virulência de linhagens, condições de co-cultura, antibióticos a serem utilizados para a eliminação da Agrobacterium e agentes seletivos em tecidos com potencial de regeneração de plantas in vitro. A utilização de calos para a transformação genética via Agrobacterium é vista como a única maneira viável de se conseguir plantas transformadas de Phaseolus vulgaris. O objetivo deste trabalho foi o de se avaliar a virulência de algumas linhagens de Agrobacterium tumefaciens (GV3101 (pBECKS ${ }_{2000} 4$ ), EHA105

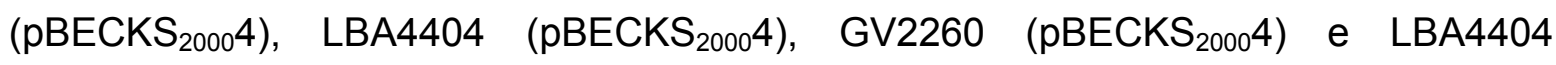
(pTOK233)), o efeito dos tempos de duração da sonicação $(0,30,60,90,120$ e $180 \mathrm{~s})$, a tolerância a várias concentrações de glufosinato de amônio $\left(\begin{array}{llll}0 & 0,01 & 0,1 & 0,2 \\ 0,4\end{array}\right.$ 0,8 1,6 e 3,2 $\mathrm{mg} \mathrm{L}^{-1}$ ) e o efeito de antibióticos (utilizados para controle da Agrobacterium), em calos organogenéticos de feijão da linhagem Xan 159 (CIAT). Os resultados demonstraram a suscetibilidade do feijão a Agrobacterium e a importância da combinação de linhagens e plasmídeos supervirulentos como a LBA4404 (pTOK233), na transformação genética do feijão. Essa linhagem foi a que apresentou a maior expressão transitória da $\beta$-glucuronidase. O tempo de sonicação de calos de feijão de 60 segundos produziu o melhor resultado, observado pelo aumento significativo da expressão transitória da $\beta$-glucuronidase. Os calos de feijão, cultivados por 30 dias, em presença de glufosinato de amônio, mostraram suscetibilidade ao mesmo nas concentrações de $0,1 \mathrm{mg} \mathrm{L}^{-1}$ ( $20 \%$ de calos mortos) e $0,2 \mathrm{mg} \mathrm{L}^{-1}$ ( $80 \%$ dos calos mortos). Com $0,4 \mathrm{mg} \mathrm{L}^{-1}$ de glufosinato de amônio todos os calos morreram antes dos 30 dias de cultivo. Dentre os antibióticos utilizados para o controle da 
Agrobacterium após o co-cultivo, a cefotaxima foi o único que não interferiu no crescimento dos calos. 


\section{TRANSFORMATION OF ORGANOGENIC CALLUS OF Phaseolus vulgaris VIA Agrobacterium}

\section{Summary}

Bean (Phaseolus vulgaris L.) is a recalcitrant species to genetic transformation, especially via Agrobacterium. Studies of the virulence of strains, coculture conditions, antibiotics used to control the Agrobacterium, selective agents of cells are necessary in tissues which are able to regenerate plants in vitro. The use of callus in genetic transformation via Agrobacterium is seen as the most viable way of obtaining transformed plants of Phaseolus vulgaris. The aim of this work was evaluate the virulence of the Agrobacterium tumefaciens strains (GV3101 (pBECKS20004), EHA105 (pBECKS20004), LBA4404 (pBECKS20004), GV2260 (pBECKS20004) and LBA4404 (pTOK233)), duration of sonication treatment (0, 30, 60, 90, 120 and $180 \mathrm{~s}$ ), tolerance to glufosinate ammonium $\left(0,0.01,0.1,0.2,0.4,0.8,1.6\right.$ and $\left.3.2 \mathrm{mg} \mathrm{L}^{-1}\right)$ and the effects of the antibiotics: cefotaxime, vancomicin and ciprofloxacine cloridrate, in the growth of Phaseolus vulgaris callus of the breeding line Xan 159, CIAT. The results demonstrate the susceptibility of bean to Agrobacterium and the importance of the strain used and also its binary plasmid in genetic transformation, as shown by the strain LBA4404 (pTOK233). The sonication of callus for 60 seconds gave the best result, with a significant increase in transient expression of the $\beta$-glucuronidase. The growth of callus cultivated by 30 days in the presence of glufosinate ammonium was inhibited in concentrations of $0.1 \mathrm{mg} \mathrm{L}^{-1}$ (20\% of callus died) and $0.2 \mathrm{mg} \mathrm{L}^{-1}$ ( $80 \%$ of the callus died). With $0.4 \mathrm{mg} \mathrm{L}^{-1}$ of glufosinate ammonium the inhibition was complete. Among the used antibiotics the cefotaxime was the only one that did not interfered with the callus growth. 


\subsection{Introdução}

O feijão é uma leguminosa de importância econômica mundial, em especial para os países em desenvolvimento como o Brasil, onde representa a principal fonte calórico-protéica de origem vegetal, além de ser o responsável pela absorção de grande parte da mão de obra agrícola.

Com o advento da tecnologia do DNA recombinante associado à cultura de tecidos tem sido possível a transferência de genes para muitas espécies de plantas. Isto criou expectativas de melhoria de características das plantas, havendo grande interesse no domínio das metodologias de transformação genética. A maioria das espécies leguminosa apresenta dificuldades de transformação, e em especial o feijão (Phaseolus vulgaris) (Nagl et al., 1997). O desenvolvimento de pesquisas recentes tem permitido a regeneração de plantas através de calos, abrindo assim, novas perspectivas para a transformação de feijão via Agrobacterium (Capitulo 1).

A possibilidade de mudanças que permitam alterar características como a arquitetura e a capacidade fotossintética poderiam resultar em aumento da estabilidade de produção e da produtividade. A falta de um sistema eficiente de transformação de feijão, para a introdução de transgenes de interesse, de maneira rápida e eficiente, não tem permitido o estudo dos possíveis efeitos de genes como o Lhcb1*2 de ervilha, que codifica a proteína CAB ('Chorophyl a/b binding') de 28kDa do sistema antena LHCII, associada ao fotossistema II nos tilacóides dos cloroplastos. Plantas transgênicas de tabaco (Nicotiana tabacum) que superexpressam esta proteína, apresentam, em baixa luminosidade, aumento da biomassa e da capacidade fotossintética, entre outros efeitos pleiotrópicos (Real, 1997). A superexpressão desta proteína em plantas de feijão poderia representar uma importante contribuição para aumentar a eficiência de cultivos consorciados.

Este tem como objetivo estabelecer um protocolo de transformação de calos de feijão, via Agrobacterium, para estudar posteriormente o comportamento de genes de interesse como o $L h c b 1{ }^{*} 2$ em feijão. 


\subsection{Material e métodos}

\subsubsection{Material vegetal e cultura de tecidos}

O material vegetal utilizado para os experimentos de transformação foi calo induzido a partir da região de inserção do cotilédone com o eixo embrionário, de sementes de feijão (Phaseolus vulgaris L.) linhagens Xan 159 (CIAT), do Banco de germoplasma do CENA, cultivadas em casa de vegetação (Capitulo 1).

\subsubsection{Linhagens de Agrobacterium tumefaciens, plasmídeos e condições de cultura}

As linhagens de Agrobacterium tumefaciens com os respectivos plasmídeos binários utilizados foram: GV3101 (pBECKS 20004$)$, EHA105 (pBECKS $\left.{ }_{2000} 4\right)$, LBA4404 (pBECKS 20004$),$ GV2260 (pBECKS 20004$)$ e LBA4404 (pTOK233).

$\mathrm{O}$ vetor binário pBECKS ${ }_{2000} 4$ (Figura 12A) possui, na região do T-DNA, gene de resistência a canamicina (nptll), gene de resistência ao herbicida glufosinato de amônio (bar) e gene da $\beta$-glucuronidase com um intron que inibe a expressão deste em procariontes (uidA-intron) e, fora da região do T-DNA, possui gene bacteriano de resistência a espectinomicina (spc/str) (McCormac et al., 1999). O gene uidA expressa a proteína $\beta$-glucuronidase, que em presença do substrato 5 -bromo-4-cloro-3-indolyl glucurônico (X-Gluc) (Anexo C) produz dimerização oxidativa do mesmo, formando precipitado insolúvel de intensa coloração azul (Jefferson, 1987).

O vetor binário pTOK233 (Figura 12B) caracteriza-se por possui um inserto com os genes virB, virC e virG, provenientes de plasmídeo Ti 'super virulento'. A região do T-DNA possui gene de resistência a canamicina (nptll), gene de resistência a higromicina (hpt) e gene da $\beta$-glucuronidase (uidA) (Hiei et al., 1994; Ishida et al., 1996).

A Agrobacterium foi crescido sob agitação constante de $200 \mathrm{rpm}$, a $28^{\circ} \mathrm{C}$ em meio $A B\left(\right.$ Anexo $D$ ) até atingir a fase logarítmica de crescimento $\left(D_{600}=0,7\right.$ a 0,8), a partir de colônia isolada, crescida em meio sólido em placa a $28{ }^{\circ} \mathrm{C}$ por 48 a 72 horas. Após o crescimento em meio líquido (36 a 48 horas) as bactérias foram 
sedimentadas por centrifugação a $4500 \mathrm{~g}$ por 10 minutos e ressuspendidas em meio

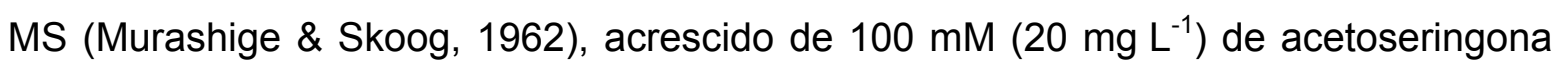
(3'5'-Dimethoxy-4'-hydroxy-acetophenone) para a co-cultura líquida (Stachel et al., 1985).

Os antibióticos utilizados para o crescimento da Agrobacterium foram os seguintes: rifampcina (100 mg ml-1) e espectinomicina (150 $\mathrm{mg} \mathrm{ml}^{-1}$ ) para as linhagens EHA105 (pBECKS $\left.{ }_{2000} 4\right), \quad$ LBA4404 (pBECKS $\left.{ }_{2000} 4\right)$ e GV2260 (pBECKS 20004$) ;$ rifampcina $\left(100 \mathrm{mg} \mathrm{ml}^{-1}\right)$, espectinomicina $\left(150 \mathrm{mg} \mathrm{ml}^{-1}\right)$ e gentamicina $\left(100 \mathrm{~g} \mathrm{ml}^{-1}\right)$ para a linhagem GV3101 $\left(\mathrm{pBECKS}_{2000} 4\right)$ e; rifampcina $\left(100 \mathrm{mg} \mathrm{m}^{-1}\right)$, canamicina $(25 \mathrm{mg}$ $\mathrm{ml}^{-1}$ ) e higromicina (50 mg ml$^{-1}$ ) para a linhagem LBA4404(pTOK233). Os antibióticos foram esterilizados por filtragem (filtro com poro de $22 \mu$ ) e adicionados ao meio de cultura em condições assépticas, após a autoclavagem. Quando a Agrobacterium foi crescido no meio líquido não se utilizou o antibiótico rifampcina.

\subsubsection{Inoculação e co-cultura}

Calos de feijão, aos 25 dias de cultivo foram colocados em frascos de vidro estéreis $(200 \mathrm{ml})$ contendo $30 \mathrm{ml}$ de meio MS líquido com $2 \%$ de sacarose, e sonicados utilizando sonicador de banho (modelo ULTRA-SOM T14, 40 kHz, Eletrônicos Thornton INPEC, Piracicaba SP), antes de serem inoculados com Agrobacterium. Imediatamente após a sonicação procedeu-se a inoculação com Agrobacterium e os frascos com os calos foram mantidos a $25 \pm 3{ }^{\circ} \mathrm{C}$ por 3 horas sob agitação constante (100 rpm). Após a co-cultura líquida os explantes foram transferidos para placas com meio CC para o cocultivo sólido por dois dias. Ao fim da co-cultura sólida os explantes foram transferidos para meio CC com cefotaxima (100 $\mathrm{mg} \mathrm{L}^{-1}$ ) para controlar a Agrobacterium, onde permaneceram até o momento da revelação da atividade GUS. 


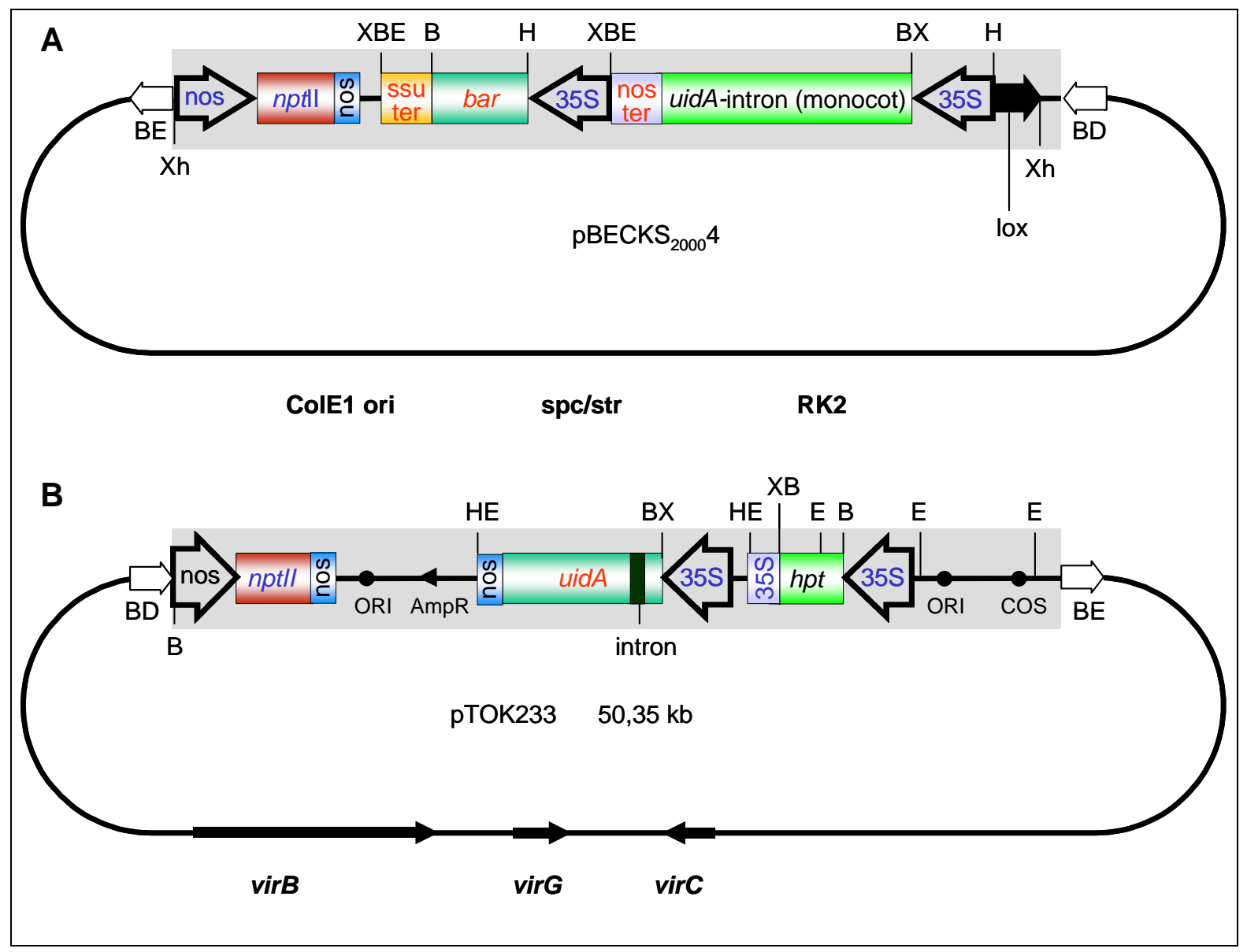

Figura 12. Diagrama esquemático dos plasmídeos utilizados: A) plasmídeo pBECKS 20004 com os genes uidA-intron, bar e nptIl (McCormac et al., 1999) e B) plasmídeo pTOK233 com os genes nptll, uidA-intron e hpt (Hiei et al., 1994). Abreviaturas: $\mathrm{BD}$ e $\mathrm{BE}$ - bordas direita e esquerda do T-DNA; spc/str - gene bacteriano para resistência à espectinomicina e estreptomicina; ORI - origem de replicação em Escherichia coli, RK2 - origem de replicação em Agrobacterium, lox - sítio de reconhecimento para a recombinação mediada por Cre, nos - nopalina sintetase (promotor ou sinal de terminação poliadenina); 35S - promotor CaMV 35S, bar - fosfinotricina acetiltransferase, ssu - gene subunidade menor de soja, nptII - neomicina fosfotransferase II; hpt higromicina fosfotransferase; uid $A$ - gene da $\beta$-glucuronidase, com intron (pBECKS 20004 com intron da catalase do milho); B - BamHl; H - Hindlll; X Xba1; Xh - Xhol; E - EcoR1; AmpR - gene bacteriano para resistência à ampicilina, ativo em E. coli; ORI - origem de replicação de ColE1; virB, virG e virC-genes de virulência de Agrobacterium, fora da região do T-DNA. 


\subsubsection{Ensaio histoquímico da $\beta$-glucuronidase para avaliação da eficiência de transformação}

A expressão da $\beta$-glucuronidase (GUS) foi avaliada pelo ensaio histoquímico descrito por Jefferson et al. (1987) e Lacorte (1998). Os calos foram imersos na solução contendo: $10 \mathrm{mM} \mathrm{Na}{ }_{2}$ EDTA. $\mathrm{H}_{2} \mathrm{O}, 0,1 \%$ Triton X-100, $100 \mathrm{mM}$ $\mathrm{NaH}_{2} \mathrm{PO}_{4}, 0,5 \mathrm{mM} \mathrm{K}_{3} \mathrm{Fe}(\mathrm{CN})_{6}$, e 0,5 $\mathrm{mg} \mathrm{ml}^{-1}$ 5-bromo-4-chloro-3-indolyl $\beta$-D-glucuronico acid (X-Gluc, Inalco-USA) (Anexo C) e mantidos por 24 h a $37^{\circ} \mathrm{C}$. Após este período, foram transferidos para uma solução de etanol e ácido acético (9:1) e mantidos nessa por duas horas para eliminar a clorofila e em seguida, transferidos para etanol $70 \%$.

\subsubsection{Suscetibilidade de calos de feijão às linhagens de Agrobacterium}

A suscetibilidade de calos de feijão a diferentes às linhagens de Agrobacterium tumefaciens foi avaliada em calos de feijão aos 25 dias de desenvolvimento em meio CC. Os calos foram inoculados com as linhagens GV3101 $\left(p_{B E C K S} 20004\right), \quad$ EHA105 $\quad\left(\right.$ pBECKS $\left._{2000} 4\right), \quad$ LBA4404 $\quad\left(\right.$ pBECKS $\left._{2000} 4\right), \quad$ GV2260 (pBECKS 20004$)$ e LBA4404 (pTOK233). O delineamento experimental foi o de blocos ao acaso, com 4 repetições, considerando-se cada placa de Petri como a unidade experimental. O experimento foi realizado aos 5, 10 e 15 dias após a inoculação. 0 grau de suscetibilidade foi avaliado considerando-se o número de regiões com expressão GUS, por placa de Petri.

\subsubsection{Efeito do tempo de duração da sonicação na infecção dos tecidos por Agrobacterium}

O efeito da sonicação dos tecidos antes da inoculação com Agrobacterium foi avaliado utilizando-se a linhagem LBA4404 (pTOK233), em calos desenvolvidos em meio CC, aos 25 dias. Seis tempos de duração da sonicação $(0,30,60,90,120$ e 180 s) foram avaliados. O delineamento experimental foi o de blocos ao acaso, com 4 repetições, considerando-se cada placa de Petri como a unidade experimental. Avaliou-se o número de calos que apresentaram pelo menos uma região com expressão GUS, expressos em porcentagem. Três experimentos com avaliações aos 5, 10 e 15 dias após a inoculação, foram conduzidos. 


\subsubsection{Tolerância dos calos de feijão ao agente seletivo glufosinato de amônio}

O nível de tolerância dos calos de feijão ao glufosinato de amônio (GA) foi avaliado, visando sua utilização como agente seletivo nos experimentos de transformação. Os calos foram cultivados em meio CC, contendo concentrações crescentes de GA $\left(0 ; 0,01 ; 0,1 ; 0,2 ; 0,4 ; 0,8 ; 1,6\right.$ e $\left.3,2 \mathrm{mg} \mathrm{L}^{-1}\right)$. O delineamento experimental foi o de blocos ao acaso, com 4 repetições, considerando-se a placa de Petri como a unidade experimental. Os resultados foram obtidos utilizado-se a taxa de calos vivos, expressa em porcentagem.

\subsubsection{Eliminação da Agrobacterium dos calos de feijão}

Para o controle da Agrobacterium após o período de co-cultivo avaliou-se os antibióticos cefotaxima, vancomicina e cloridrato de ciprofloxacino. A nota número 1 foi atribuída aos calos com comportamento normal, notas de 2 a 4 quando surgiram pequenas modificações perceptíveis visualmente, como pontos de tecido morto e nota 5 ou acima quando se observou morte de regiões do calo correspondentes a $15 \%$ ou mais da área do calo.

No caso da cefotaxima os calos não inoculados foram colocados em meio CC contendo $0,100,200,400$ e $500 \mathrm{mg} \mathrm{L}^{-1}$. Já para a vancomicina, os calos não inoculados foram colocados em meio CC contendo 0, 100, 200, 400, 600 e $1000 \mathrm{mg}$ $\mathrm{L}^{-1}$. E para o cloridrato de ciprofloxacino, os calos não inoculados foram colocados em meio CC contendo $0,10,50,100$ e $500 \mathrm{mg} \mathrm{L}^{-1}$.

O delineamento experimental foi o de blocos ao acaso com 4 repetições, considerando-se a placa de Petri como a unidade experimental, atribuindo-se uma nota quanto ao efeito de cada antibiótico sobre o desenvolvimento dos calos, com 30 dias de cultivo em meio CC.

\subsection{Resultados e discussão}

O feijão apresenta inúmeras dificuldades para a transformação genética. Estas dificuldades vão desde a cultura de tecidos e regeneração de plantas, passando pela dificuldade de transformar via Agrobacterium tecidos competentes para regenerar 
plantas, até a seleção de células transformadas. Durante a definição do protocolo de transformação genética de feijão via Agrobacterium são necessários ajustes para avaliar-se a eficiência do sistema e definir as correções possíveis. Estes ajustes do protocolo de transformação iniciam-se pela definição da linhagem de Agrobacterium a ser utilizada até a determinação dos procedimentos de seleção das células transformadas. A seguir são apresentados os resultados de experimentos realizados com o objetivo de otimizar os parâmetros da transformação de calos de feijão competentes para a regeneração de plantas.

\subsubsection{Suscetibilidade de calos de feijão às linhagens de Agrobacterium}

Os calos de feijão, competentes para a regeneração de plantas, apresentaram suscetibilidade diferenciada às linhagens de Agrobacterium e seus respectivos plasmídeos binários (Figura 13). A taxa de expressão GUS nos calos inoculados com a linhagem LBA4404 (pTOK233) foi superior aos calos inoculados com as demais linhagens e seus respectivos plasmídeos. Os calos inoculados com a linhagem LBA4404 (pBECKS $\left.{ }_{2000} 4\right)$ apresentaram expressão GUS superior aos calos inoculados com as linhagens GV3101 (pBECKS 20004$)$ e GV2260 (pBECKS 20004$)$, porém não diferiu significativamente dos calos inoculados com a linhagem EHA105 $\left(\right.$ pBECKS $\left._{2000} 4\right)$. Os resultados evidenciam a importância da combinação linhagem plasmídeo binário a ser utilizada. Quando a linhagem LBA4404 foi utilizada em combinação com o plasmídeo pTOK233 os calos inoculados apresentaram o dobro de expressão GUS em relação à combinada com o plasmídeo $\mathrm{pBECKS}_{2000} 4$. Este fato pode ser explicado pela presença de genes de virulência (virB, virG e virC), com expressão constitutiva também no plasmídeo binário, derivados do plasmídeo Ti 'super virulento' pTiBo542 (Jin et al., 1987). A presença destes genes aumenta a virulência desta linhagem e conseqüentemente, a freqüência de regiões com expressão GUS.

Nos experimentos avaliados aos 10 e 15 dias, nenhum calo apresentou regiões com expressão GUS. Estes resultados indicam que, embora tenha ocorrido expressão transitória dos genes introduzidos na célula vegetal via Agrobacterium, não houve a integração no genoma do feijão. Muitas vezes, a expressão do gene introduzido é instável, podendo diminuir ou mesmo desaparecer durante o 
desenvolvimento da planta transgênica. Há estudos que mostram a necessidade da expressão de algumas proteínas da planta para que se efetive a transformação genética, em determinadas espécies (Tzfira \& Citovsky, 2002; Tzfira et al., 2002).

\subsubsection{Efeito da duração do tempo de sonicação na infecção dos tecidos pela Agrobacterium}

Um dos fatores que afetam a eficiência do processo de transformação com Agrobacterium, assistida pela sonicação é o tempo de exposição do material ao ultrasom. Neste experimento, avaliou-se o efeito de diferentes tempos de sonicação antes da inoculação, em calos avaliados para atividade da $\beta$-glucuronidase após 5 dias da inoculação com a linhagem de Agrobacterium LBA4404 (pTOK 233) (Figura 14). O número de calos com regiões que apresentam expressão transitória GUS aumentou com o tempo de duração da sonicação até o tratamento de 60 segundos, porém não diferindo significativamente da testemunha, não sonicada. Para os tempos de sonicação superiores a 60 segundos os calos passaram a apresentar regiões com pontos de oxidação, inviabilizando o calo e reduzindo a porcentagem de calos com regiões expressando GUS. Trick \& Finer (1997) avaliaram os tempos de 1 a 100 segundos e observaram que a presença de microferimentos aumentava proporcionalmente ao tempo de duração da sonicação, embora um tempo prolongado causasse danos aos tecidos, prejudicando assim, a posterior regeneração dos mesmos (Joersbo \& Brunstedt, 1992). 


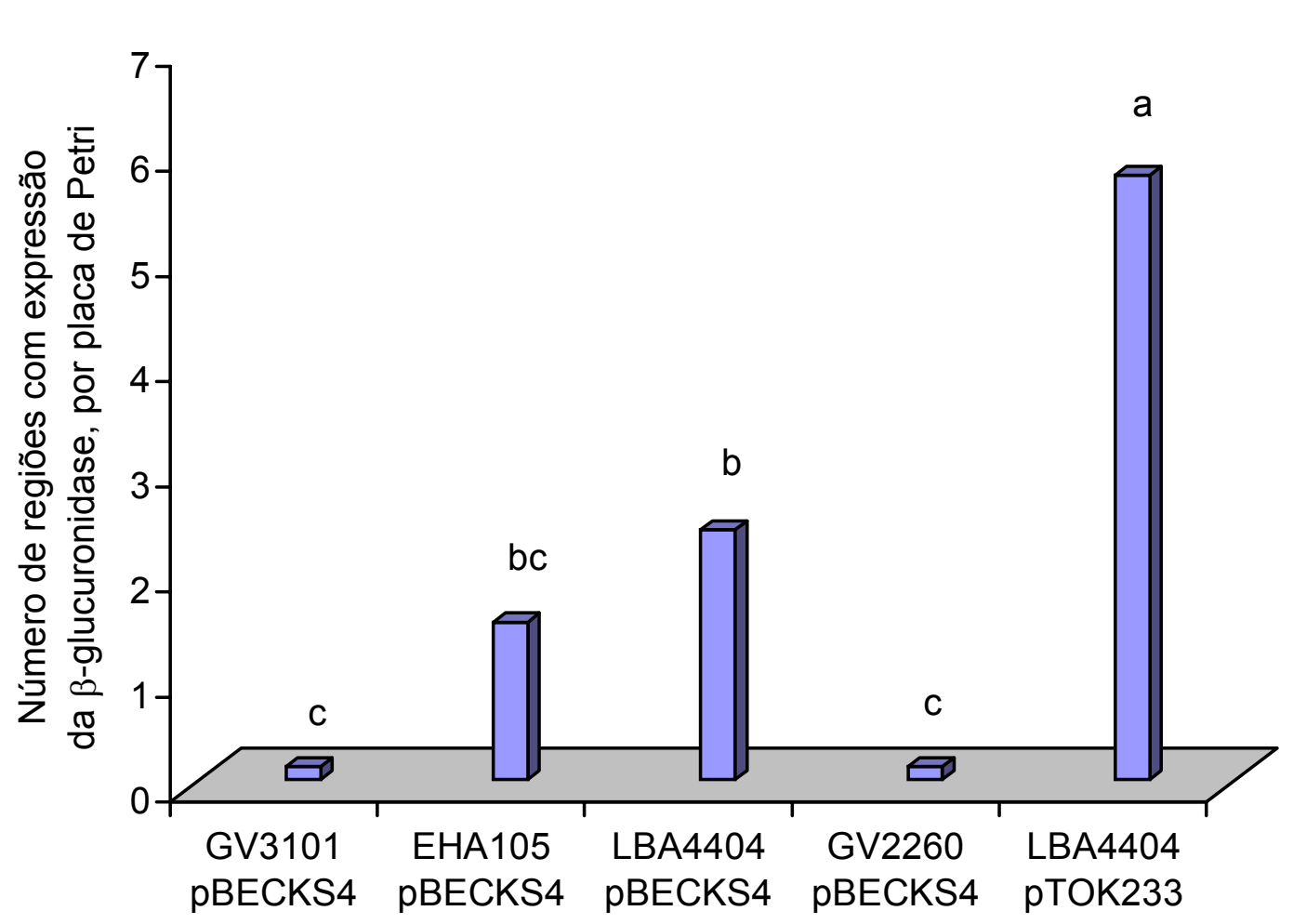

Linhagem de Agrobacterium e plasmídeo

Figura 13. Suscetibilidade de calos de feijão a diferentes linhagens de Agrobacterium e respectivos plasmídeos binários (GV3101 (pBECKS $\left.{ }_{2000} 4\right)$, EHA105 $\left(\right.$ pBECKS $\left._{2000} 4\right), \quad$ LBA4404 $\quad\left(\right.$ pBECKS $\left._{2000} 4\right), \quad$ GV2260 $\left(\right.$ pBECKS $\left._{2000} 4\right)$ e LBA4404 (pTOK233)), expressa através do número de regiões com expressão GUS, por placa com 5 calos, aos 5 dias após a inoculação. Médias não seguidas pela mesma letra diferem pelo teste de Duncan $(p<0,05)$.

Trick \& Finner (1997), sugerem que o tempo de sonicação utilizado nos experimentos deve ser suficiente para se obter alta eficiência de transformação, tendose o cuidado de que os danos causados nos tecidos não afetem o processo de regeneração dos mesmos. Assim, pelos resultados obitodos os tratamentos com tempos superiores a 60 segundos de sonicação não são indicados para calos de feijão crescidos por 25 dias em meio CC, pois causaram danos nos tecidos dos calos, o que levou a uma diminuição do número de calos com regiões expressando a $\beta$ glucuronidase. 
Os experimentos avaliados quanto à atividade da $\beta$-glucuronidase aos $10 \mathrm{e}$ aos 15 dias após a inoculação não apresentaram nenhuma região com expressão transitória da $\beta$-glucuronidase. $O$ padrão de expressão da $\beta$-glucuronidase apresenta um comportamento semelhante na maioria das espécies estudadas. Se inicia poucas horas após a inoculação, atinge um valor máximo de expressão algumas horas após a inoculação e reduz-se com o passar do tempo, até atingir níveis estáveis de expressão (Klein et al., 1987; Finer \& McMullen, 1990; De Andrade, 2001).

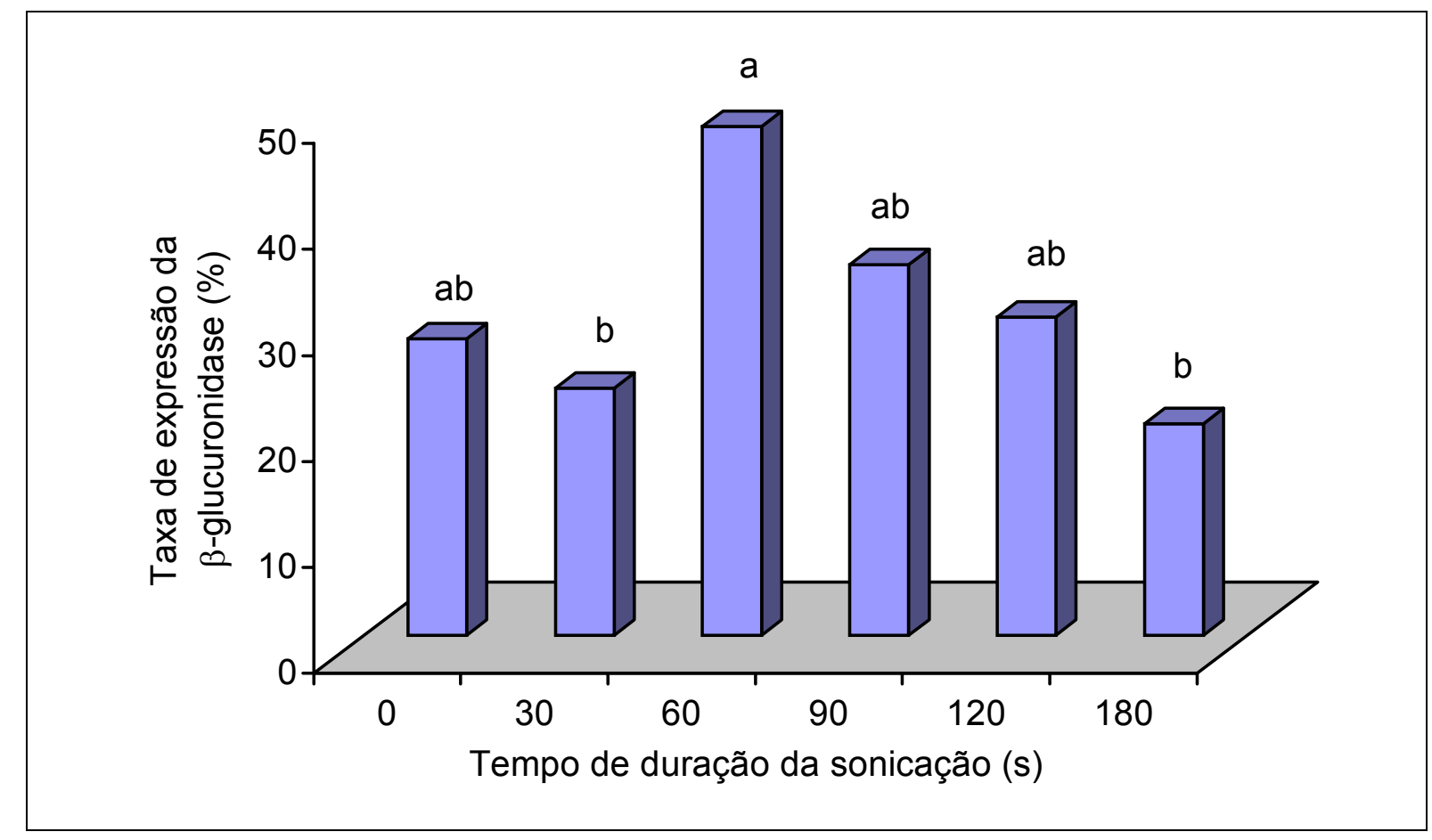

Figura 14. Efeito do tempo de duração da sonicação na eficiência do processo de transformação de calos de feijão, avaliado pela porcentagem de calos com regiões expressando a $\beta$-glucuronidase, aos 5 dias após a inoculação. Médias não seguidas pela mesma letra diferem significativamente pelo teste de Tukey-Kramer $(p<0,05)$.

Klein et al. (1988) observaram uma taxa de $5 \%$ de expressão estável, enquanto Finer \& McMullen (1990) observaram menos de 1\%. O aumento da porcentagem de expressão transitória é fundamental para a obtenção de calos de feijão transformados. O aumento da expressão transitória e da expressão estável depende de condições favoráveis do meio de cultura e das condições fisiológicas do explante, no momento da inoculação. Estas condições podem ser ajustadas a partir de 
resultados como os obtidos por Ezura et al. (2000). Os autores sugerem que o etileno afeta a transferência de genes via Agrobacterium para explantes retirados de cotilédones de melão, diminuindo a eficiência do processo. Componentes das rotas de transdução de sinais que regulam a biossíntese de etileno em Arabidopsis thaliana, foram identificados pela caracterização da resposta de mutantes ao etileno (Bleecker \& Kende, 2000). Nesse caso, uma das classes de mutantes permitiu a identificação de receptores de etileno relacionados a sistemas de sinalização bacteriana.

\subsubsection{Tolerância de calos de feijão ao agente seletivo glufosinato de amônio}

A eficiência de transformação de uma determinada espécie está relacionada ao sistema de seleção das células ou tecidos transformados. O sistema de seleção deve inibir o crescimento e o desenvolvimento dos tecidos não transformados, favorecendo ou permitindo que as células ou tecidos transformados se desenvolvam, com vantagem seletiva. O glufosinato de amônio já foi utilizado com sucesso na seleção de brotos de feijão transformados por biobalística e regenerados de multibrotações induzidas no eixo embrionário (Aragão et al., 2002). Porém ainda não foi utilizado em meio de cultura para selecionar células ou tecidos de calos transformados, via Agrobacterium.

O primeiro passo para a utilização de um agente seletivo é encontrar a concentração adequada que permita a seleção diferencial em favor dos tecidos transformados.

Neste experimento foram avaliadas diferentes concentrações de glufosinato de amônio $\left(0 ; 0,01 ; 0,1 ; 0,2 ; 0,4 ; 0,8 ; 1,6\right.$ e $3,2 \mathrm{mg} \mathrm{L}^{-1}$ ) (Figura 15). $\mathrm{Na}$ concentração de $0,1 \mathrm{mg} \mathrm{L}^{-1}$ de glufosinato de amônio a taxa de sobrevivência dos calos vivos reduziu significativamente para $80 \%$. E na concentração de $0,4 \mathrm{mg} \mathrm{L}^{-1}$ de glufosinato de amônio $100 \%$ dos calos morreram após 30 dias de contato com o meio de cultura. Esses resultados mostram que as concentrações de glufosinato de amônio a serem utilizadas para seleção de tecidos de calos de feijão transformados por Agrobacterium devem estar entre 0,1 e $0,4 \mathrm{mg} \mathrm{L}^{-1}$. 


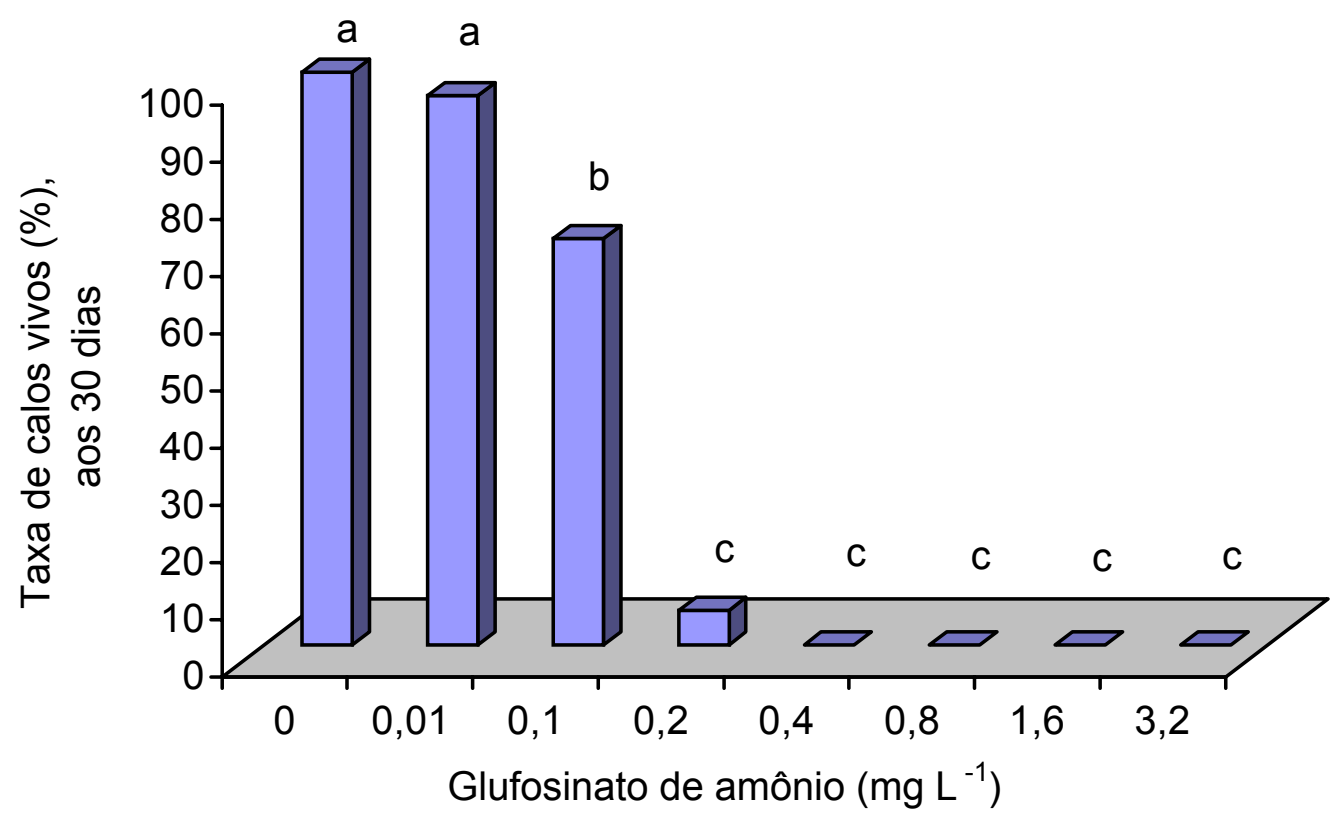

Figura 15. Suscetibilidade de calos de feijão a diferentes concentrações do agente seletivo glufosinato de amônio $\left(\mathrm{mg} \mathrm{L}^{-1}\right)$, expresso através da porcentagem de calos vivos, aos 30 dias. Médias não seguidas pela mesma letra diferem significativamente pelo teste de Tukey-Kramer $(p<0,0001)$.

\subsubsection{Eliminação da Agrobacterium de calos de feijão}

A eliminação da Agrobacterium dos tecidos após a co-cultura em meio de cultura sólido é fundamental para o crescimento e desenvolvimento dos tecidos transformados, pois a bactéria compete por nutrientes. Os antibióticos cefotaxima sódica, vancomicina e cloridrato de ciprofloxacino, foram eficientes no controle do Agrobacterium nas doses de 100, 200 e $50 \mathrm{mg} \mathrm{L}^{-1}$, respectivamente. Entretanto, os efeitos indesejáveis de alguns destes antibióticos podem surgir mesmo em concentrações menores do que as necessárias para o controle da Agrobacterium na cultura de calos. Pela Figura 16, observa-se que a cefotaxima sódica foi o antibiótico que menos interferiu com o desenvolvimento dos calos (Figura 16A). Quanto ao cloridrato de ciprofloxacino seria recomendado uma avaliação de concentrações entre 10 e $50 \mathrm{mg} \mathrm{L}^{-1}$, obtendo assim um nível de controle da Agrobacterium que não interfira com o desenvolvimento dos tecidos vegetais. 
A)

B)

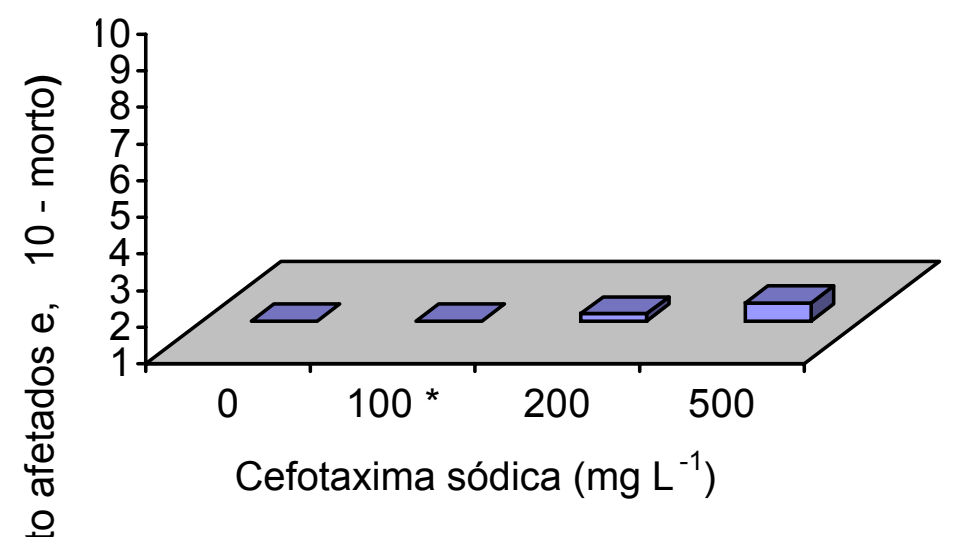

C)

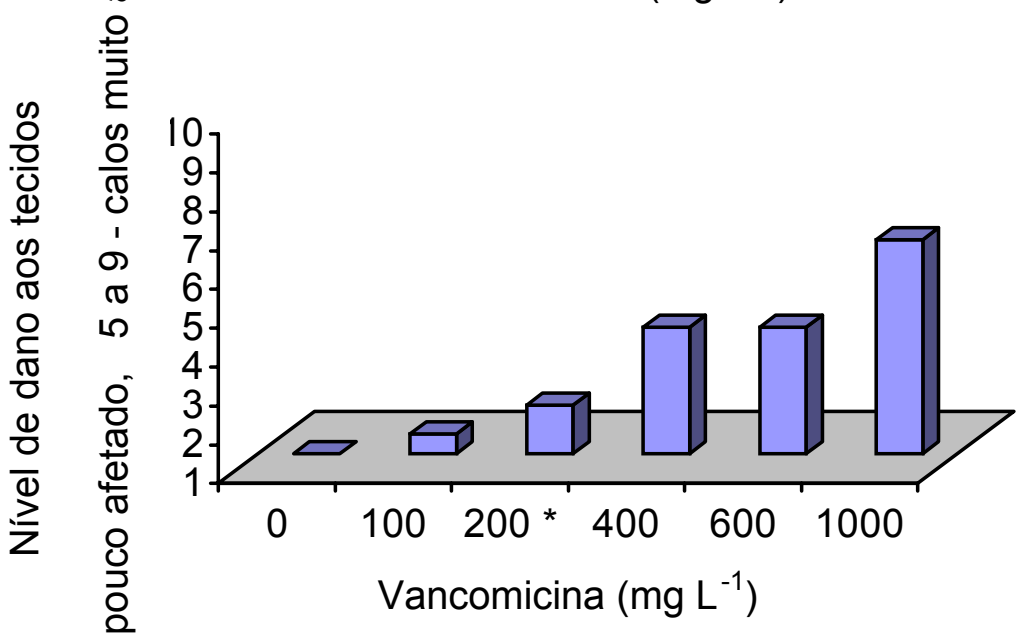

)

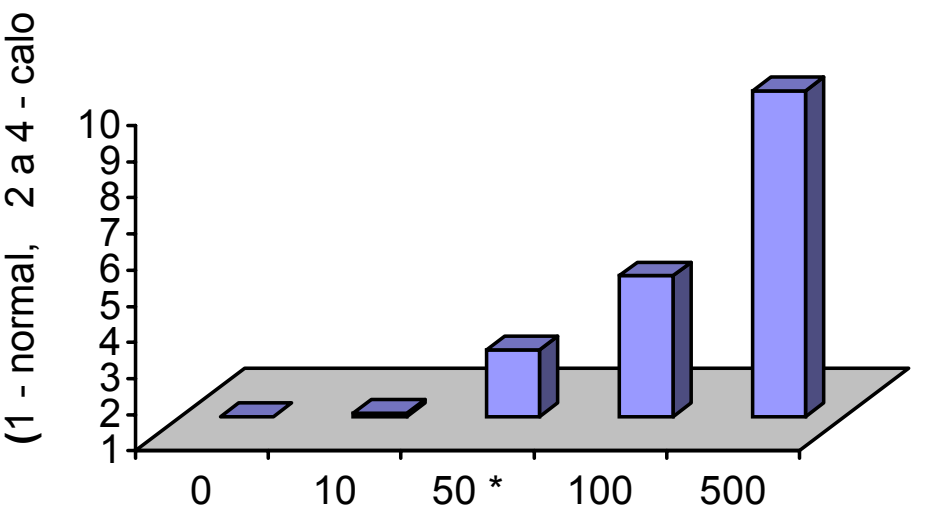

Cloridrato de ciprofloxacino $\left(\mathrm{mg} \mathrm{L}^{-1}\right)$

Figura 16. Nível de dano causado aos calos de feijão cultivados em meio CC durante 30 dias em diferentes concentrações de A) cefotaxima sódica, B) vancomicina e C) cloridrato de ciprofloxacino, expresso através de nota (1 calo normal, 2 a 4 - calos com modificações no aspecto geral e maior quantidade de tecido morto e, 5 a 10 - calos bastante afetados pelo antibiótico e regiões mortas, variando de 20 a $100 \%$ do calo). * Concentração mínima necessária, para o controle da Agrobacterium em calos de feijão em meio CC. 


\subsection{Conclusões}

1) Calos de feijão da linhagem Xan 159 (CIAT) são suscetíveis à infecção por Agrobacterium, destacando-se a linhagem LBA4404 (pTOK233).

2) A sonicação dos calos por um período de 60 segundos contribuiu para aumentar a taxa de calos com expressão transitória da $\beta$-glucuronidase.

3) O glufosinato de amônio, como agente seletivo de células e tecidos transformados, em calos de feijão linhagem Xan 159 (CIAT), deve ser utilizado em concentrações entre 0,1 e $0,4 \mathrm{mg} \mathrm{L}^{-1}$.

4) A cefotaxima sódica, na concentração de $100 \mathrm{mg} \mathrm{L}^{-1}$, não apresentou efeitos inibitórios ao desenvolvimento dos calos de feijão, sendo eficiente no controle da Agrobacterium linhagem LBA4404 (pTOK 233). 


\section{CONCLUSÕES GERAIS}

Este trabalho descreve uma metodologia de regeneração plantas de Phaseolus vulgaris sexualmente férteis, através da organogênese indireta;

A regeneração de plantas pela organogênese indireta pode ser utilizada em experimentos de transformação genética do feijão via Agrobacterium; na busca de variabilidade genética através da variação somaclonal e na seleção in vitro para variantes resistentes a doenças;

Os calos de feijão linhagem Xan 159 (CIAT) apresentaram suscetibilidade a Agrobacterium tumefaciens e;

A sonicação dos calos por um período de 60 segundos contribuiu para aumentar a taxa de calos com regiões com expressão transitória da $\beta$-glucuronidase. 


\section{ANEXOS}

Anexo A - Componentes do meio de cultura basal (BA)

Macronutrientes (Murashige \& Skoog, 1962)

Estoque (20x) usar $50 \mathrm{ml} \mathrm{L}^{-1}$

\begin{tabular}{|c|c|c|c|c|}
\hline Componentes & PM & $m g L^{-1}$ & $\mathrm{mM} \mathrm{L}^{-1}$ & $\begin{array}{l}\text { Estoque (20x) } \\
\text { g } 500 \mathrm{ml}^{-1}\end{array}$ \\
\hline $\mathrm{NH}_{4} \mathrm{NO}_{3}$ & 80,04 & 1650 & 20,6 & 16,5 \\
\hline $\mathrm{KNO}_{3}$ & 101,11 & 1900 & 18,8 & 19,0 \\
\hline $\mathrm{CaCl}_{2} .2 \mathrm{H}_{2} \mathrm{O}$ & 147,02 & 440 & 3,0 & 4,4 \\
\hline $\mathrm{MgSO}_{4} .7 \mathrm{H}_{2} \mathrm{O}$ & 246,48 & 370 & 1,5 & 3,7 \\
\hline $\mathrm{KH}_{2} \mathrm{PO}_{4}$ & 136,09 & 170 & 1,25 & 1,7 \\
\hline
\end{tabular}

Armazenar em geladeira por até 3 meses.

Micronutrientes (Murashige \& Skoog, 1962)

Estoque (1000x) usar $1 \mathrm{ml} \mathrm{L}^{-1}$

\begin{tabular}{lcccc}
\hline Componentes & $\mathbf{P M}$ & $\mathbf{\mathbf { m g ~ L } ^ { - 1 }}$ & $\mathbf{\mathbf { m M ~ L } ^ { - 1 }}$ & $\begin{array}{c}\text { Estoque (1 000x) } \\
\mathbf{9} \mathbf{1 0 0} \mathbf{~ m l}^{-1}\end{array}$ \\
\hline $\mathrm{MnSO}_{4} \cdot \mathrm{H}_{2} \mathrm{O}$ & 169,01 & 16,9 & 0,100 & 1,69 \\
$\mathrm{ZnSO}_{4} \cdot 7 \mathrm{H}_{2} \mathrm{O}$ & 287,54 & 8,6 & 0,030 & 0,86 \\
$\mathrm{H}_{3} \mathrm{BO}_{3}$ & 61,83 & 6,2 & 0,100 & 0,62 \\
$\mathrm{KI}$ & 166,01 & 0,83 & 0,005 & 0,083 \\
$\mathrm{Na}_{2} \mathrm{MoO}_{4} \cdot 2 \mathrm{H}_{2} \mathrm{O}$ & 241,95 & 0,250 & 0,001 & 0,025 \\
$\mathrm{CuSO}_{4} \cdot 5 \mathrm{H}_{2} \mathrm{O}$ & 249,68 & 0,025 & 0,0001 & 0,0025 \\
$\mathrm{CoCl}_{2} \cdot 6 \mathrm{H}_{2} \mathrm{O}$ & 237,93 & 0,025 & 0,0001 & 0,0025 \\
\hline
\end{tabular}

Armazenar em geladeira por até 3 meses. 
FeEDTA (Murashige \& Skoog, 1962)

Estoque (200x) usar $5 \mathrm{ml} \mathrm{L}^{-1}$

\begin{tabular}{|c|c|c|c|c|}
\hline Componentes & PM & $\mathrm{mg} \mathrm{L}^{-1}$ & $\mathrm{mM} \mathrm{L}^{-1}$ & $\begin{array}{l}\text { Estoque (200x) } \\
\quad \text { g } 200 \mathrm{ml}^{-1}\end{array}$ \\
\hline $\mathrm{Na}_{2}$ EDTA. $2 \mathrm{H}_{2} \mathrm{O}$ & 372,24 & 37,3 & 0,100 & 1,65 \\
\hline $\mathrm{FeSO}_{4} .7 \mathrm{H}_{2} \mathrm{O}$ & 278,02 & 27,8 & 0,100 & 1,12 \\
\hline
\end{tabular}

Adicionar primeiro o EDTA e em seguida o ferro, aquecer até atingir coloração laranja escuro.

Armazenar em frasco escuro em geladeira por até 3 meses.

Compostos orgânicos (Vitaminas B5 (Gamborg et al., 1968) e myo-inositol) Estoque de vitaminas (10000x) usar $100 \mu \mathrm{L} \mathrm{L}^{-1}$

\begin{tabular}{|c|c|c|c|}
\hline Componentes & $\mathrm{Mg} \mathrm{L}^{-1}$ & $\mathrm{mM} \mathrm{L}^{-1}$ & $\begin{array}{l}\text { Estoque }(10000 \mathrm{x}) \\
\mathrm{g} 10 \mathrm{ml}^{-1}\end{array}$ \\
\hline Ácido nicotínico & 1 & 0,008 & 0,1 \\
\hline Piridoxina $\mathrm{HCl}$ & 1 & 0,005 & 0,1 \\
\hline Tiamina $\mathrm{HCl}$ & 10 & 0,030 & 1,0 \\
\hline
\end{tabular}

Armazenar em freezer $\left(-20^{\circ} \mathrm{C}\right)$ por até 3 meses.

O myo-inositol é adicionado na forma sólida, diretamente ao meio de cultura, antes da autoclavagem (100 $\left.\mathrm{mg} \mathrm{L}^{-1}, 0,550 \mathrm{mM} \mathrm{L}^{-1}\right)$. 


\section{Anexo B - Estoques dos reguladores de crescimento}

AIA - Ácido indol acético - PM 175,2

Modo de preparo: Estoque: $1 \mathrm{mg} \mathrm{m}^{-1}$

1) pesar $10 \mathrm{mg}$ e dissolver em 3 gotas de $\mathrm{NaOH} 1 \mathrm{~N}$,

2) completar volume com água destilada, para $10 \mathrm{ml}$, esterilizar por filtragem, aliquotar.

Armazenar em freezer $\left(-20^{\circ} \mathrm{C}\right)$ por no máximo 2 meses (preferencialmente utilizálo fresco).

BAP - N6-Benzyladenine ou 6-benzilaminopurine (BA) - PM 225,3

Modo de preparo: Estoque: $10 \mathrm{mg} \mathrm{ml}^{-1}$

1) pesar $0,05 \mathrm{~g}$ e dissolver em $1 \mathrm{ml}$ de $\mathrm{KOH} 1 \mathrm{M}$,

2) Adicionar $4 \mathrm{ml}$ de água destilada.

Armazenar em geladeira $\left(-20\right.$ a $\left.4{ }^{\circ} \mathrm{C}\right)$, por no máximo 3 meses.

CPPU - N-(2-CHLORO-4-PYRIDYL)-N'-PHENYLUREA (4-CPPU) - PM 247,7

Modo de preparo: Estoque: $10 \mathrm{mg} \mathrm{ml}^{-1}$

1) Pesar $10 \mathrm{mg}$ e dissolver em $1 \mathrm{ml}$ de DMSO

2) Agitar até dissolver completamente.

Armazenar em geladeira $\left(0\right.$ a $\left.4{ }^{\circ} \mathrm{C}\right)$, por no máximo 12 meses, autoclavável.

$\mathbf{G A}_{3}$ - Ácido giberélico - PM 346,4

Modo de preparo: Estoque: $1 \mathrm{mg} \mathrm{ml}^{-1}$

1) Pesar $10 \mathrm{mg}$ e dissolver em $200 \mu \mathrm{L}$ de EtOH $50 \%$,

2) Completar volume para $10 \mathrm{ml}$.

Armazenar em geladeira (RT), autoclavável.

AIB - Ácido indolbutírico - PM 241,3

Modo de preparo: Estoque: $0,2 \mathrm{mg} \mathrm{ml}^{-1}$

1) Pesar $2 \mathrm{mg} \mathrm{e}$,

2) Dissolver em $10 \mathrm{ml}$ de água (kAIB) ou em 2 a 5 gotas de $\mathrm{NaOH} 1 \mathrm{~N}$ (AIB) e completar o volume para $10 \mathrm{ml}$.

Armazenar em geladeira $\left(0\right.$ a $\left.5{ }^{\circ} \mathrm{C}\right)$, autoclavável. 
ANA - Ácido naftalenoacético - PM 186,2

Modo de preparo: Estoque: $1 \mathrm{mg} \mathrm{ml}^{-1}$

1) Pesar $10 \mathrm{mg}$ e dissolver em 3 gotas de $\mathrm{NaOH} 1 \mathrm{~N}$,

2) Completar volume para $10 \mathrm{ml}$.

Armazenar em geladeira (RT), autoclavável.

\section{Anexo C - X-Gluc}

X-Gluc - 5-bromo-4-cloro-3-indolyl glucurônico

Modo de preparo: $200 \mathrm{ml}$

1) Colocar em um Becker $190 \mathrm{ml}$ de água destilada;

2) Adicionar os seguintes componentes

\begin{tabular}{lccc}
\hline Componente & PM & Concentração & Para $200 \mathrm{ml}$ \\
\hline $\mathrm{Na}_{2}$ EDTA. $\mathrm{H}_{2} \mathrm{O}$ & 292,2 & $10 \mathrm{mM}$ & $0,744 \mathrm{~g}$ \\
$\mathrm{NaH}_{2} \mathrm{PO}_{4} \cdot \mathrm{H}_{2} \mathrm{O}$ & 137,99 & $100 \mathrm{mM}$ & $2,76 \mathrm{~g}$ \\
$\mathrm{~K}_{4} \mathrm{Fe}(\mathrm{CN})_{6} \cdot 3 \mathrm{H}_{2} \mathrm{O}$ & 422,4 & $0,5 \mathrm{mM}$ & $0,042 \mathrm{~g}$ \\
Triton X-100 & & $0,1 \%$ & $0,200 \mathrm{ml}$ \\
\hline
\end{tabular}

3) Agitar por 10 minutos, para dissolver;

4) Ajustar o $\mathrm{pH}$ para 7,0 com pellets de $\mathrm{NaOH}$

5) Dissolver $100 \mathrm{mg}$ de X-Gluc em $2 \mathrm{ml}$ de DMSO, em frasco separado,

6) Adicionar a solução X-Gluc/DMSO (dimetil sulfoxide) na primeira solução,

7) Filtrar em filtro milipore $(0,2 \mu \mathrm{m})$,

8) Aliquotar e armazenar $\mathrm{a}-20^{\circ} \mathrm{C}$ ( 6 a 8 meses),

\section{Anexo D - Meio AB}

\section{Estoque - Tampão AB}

\begin{tabular}{|c|c|c|c|}
\hline Componente & PM & $\mathrm{g} \mathrm{L}^{-1}$ & ${\mathrm{~g} 200 \mathrm{ml}^{-1}}$ \\
\hline $\mathrm{KH}_{2} \mathrm{PO}_{4}$ & $174,18 \mathrm{~g}$ & 60 & 12 \\
\hline \multirow{2}{*}{\multicolumn{4}{|c|}{ 1) Ajustar para pH 6,6 (com HCl concentrado) }} \\
\hline & & & \\
\hline \multicolumn{4}{|c|}{ 2) Ajustar volume } \\
\hline \multicolumn{4}{|c|}{ 3) Autoclavar } \\
\hline \multicolumn{4}{|c|}{ 4) Armazenar em geladeira (no máximo 3 meses) } \\
\hline
\end{tabular}




\section{Estoque - Sais AB}

\begin{tabular}{lccc}
\hline Componente & $\mathrm{PM}$ & $\mathrm{g} \mathrm{L}^{-1}$ & $\mathrm{~g} \mathrm{200} \mathrm{ml}^{-1}$ \\
\hline $\mathrm{NH}_{4} \mathrm{Cl}$ & 53,49 & 20 & 4 \\
$\mathrm{MgSO}_{4} \cdot 7 \mathrm{H}_{2} \mathrm{O}$ & 246,48 & 6 & 1,2 \\
$\mathrm{KCl}$ & & 3 & 0,6 \\
$\mathrm{CaCl}_{2} \cdot 2 \mathrm{H}_{2} \mathrm{O}$ & 0,2 & 0,04 \\
$\mathrm{FeSO}_{4} \cdot \mathrm{H}_{2} \mathrm{O}$ & 0,05 & 0,01 \\
1) Ajustar volume & & \\
2) Autoclavar & & \\
3) Armazenar em geladeira (no máximo 3 meses) &
\end{tabular}

Para preparar 1 litro de meio $\mathrm{AB}$ :

1) Adicionam-se $5 \mathrm{~g}$ de glucose a $900 \mathrm{ml}$ de água destilada e $15 \mathrm{~g}$ de agar bacteriológico,

2) Autoclavar,

3) Em condições assépticas (fluxo laminar), adicionar $50 \mathrm{ml}$ de tampão $A B, 50 \mathrm{ml}$ de sais $A B$ e antibióticos. 


\section{REFERÊNCIAS BIBLIOGRÁFICAS}

AKASAKA, Y.; DAIMON, H.; MII, M. Improved plant regeneration from cultured leaf segments in peanut (Arachis hypogaea L.) by limited exposure to thidiazuron. Plant Science, v.156, n.2, p.169-175, 2000.

ALLAVENA, A.; ROSSETTI, L. Efforts in somatic embryogenesis of Phaseolus vulgaris L. Acta Horticulturae, v.131, p.239-246, 1983.

ANDERSON, A.R.; MOORE, L.W. Host specificity in the genus Agrobacterium. Phytopathology, v.69, n.4, p.320-323, 1979.

ANGELINI, R.R.; ALLAVENA, A. Plant regeneration from immature cotyledon explant cultures of bean (Phaseolus coccineus L). Plant Cell Tissue and Organ Culture, v.19, n.2, p.167-174, 1989.

ARAGÃO, F.J.L.; RECH, E.L. Morphological factors influencing recovery of transgenic bean plants (Phaseolus vulgaris L.) of a Carioca cultivar. International Journal of Plant Sciences, v.158, n.2, p.157-163, 1997.

ARAGÃO, F.J.L.; RECH, E.L. Isolamento de vetores para transformação direta. In: BRASILEIRO, A.C.M.; CARNEIRO, V.T.D. (Ed.). Manual de transformação genética de plantas. Brasília: EMBRAPA,SPI; EMBRAPA, CENARGEN, 1998. p.17-33.

ARAGÃO, F.J.L.; SAROKIN, L.; VIANNA, G.R.; RECH, E.L. Selection of transgenic meristematic cells utilizing a herbicidal molecule results in the recovery of fertile transgenic soybean (Glycine max L. Merril) plants at a high frequency. Theoretical and Applied Genetics, v.101, n.1-2, p.1-6, 2000.

ARAGÃO, F.J.L.; VIANNA, G.R.; ALBINO, M.M.C.; RECH, E.L. Transgenic dry bean tolerant to the herbicide glufosinate ammonium. Crop Science, v.42, p.1298-1302, 2002.

ARAGÃO, F.J.L.; SÁ, M.F.G.D.; ALMEIDA, E.R.; GANDER, E.S.; RECH, E.L. Particle bombardment-mediated transient expression of a Brazil nut methionine-rich albumin in bean (Phaseolus vulgaris L.). Plant Molecular Biology, v.20, p.357-359, 1992.

ARAGÃO, F.J.L.; SÁ, M.F.G.D.; DAVEY, M.R.; BRASILEIRO, A.C.M.; FARIA, J.C.; RECH, E.L. Factors influencing transient gene expression in bean (Phaseolus vulgaris L.) using an electrical particle aceleration device. Plant Cell Reports, v.12, p.483-490, 1993.

ARAGÃO, F.J.L.; BARROS, L.M.G.; BRASILEIRO, A.C.M.; RIBEIRO, S.G.; SMITH, F.D.; SANFORD, J.C.; FARIA, J.C. Inheritance of foreign genes in transgenic bean (Phaseolus vulgaris L.) co-transformed via particle bombardment. Theoretical and Applied Genetics, v.93, p.142-150, 1996. 
ARAGÃO, F.J.L.; BARROS, L.M.G.; SOUSA, M.V.D.; SÁ, M.F.G.D.; ALMEIDA, E.R.P.; GANDER, E.S.; RECH, E.L. Expression of a methionine-rich storage albumin from the Brazil nut (Bertholletia excelsa H.B.K., Lecythidaceae) in transgenic bean plants (Phaseolus vulgaris L., Fabaceae). Genetics and Molecular Biology, v.22, n.3, p.445-449, 1999.

ARAUJO, R.S.; RAVA, C.A.; STONE, L.F.; ZIMMERMANN, M.J.D.O. Cultura do feijoeiro comum no Brasil. Piracicaba: Associação Brasileira para Pesquisa da Potassa e do Fosfato, 1996. 786p.

ARCHILLETTI, T.; LAURI, P.; DAMIANO, C. Agrobacterium-mediated transformation of almond leaf pieces. Plant Cell Reports, v.14, n.5, p.267-272, 1995.

BAILEY, M.A.; BOERMA, H.R.; PARROTT, W.A. Inheritance of Agrobacterium tumefaciens-induced tumorigenesis of soybean. Crop Science, v.34, n.2, p.514519, 1994.

BARROS, L.M.G.; GAMA, M.I.C.S.; GONCALVES, C.H.R.D.; BARRETO, C.C.; SANTANA, E.F.; CARNEIRO, V.T.D. Cultura de tecidos de feijoeiro visando à introdução de genes exógenos. Pesquisa Agropecuária Brasileira, v.32, n.3, p.267-275, 1997.

BARROS, L.M.G.; CARNEIRO, V.T.D.C. Eletroporação de protoplastos. In: BRASILEIRO, A.C.M.; CARNEIRO, V.T.D. (Ed.). Manual de transformação genética de plantas. Brasília: EMBRAPA,SPI; EMBRAPA, CENARGEN, 1998. p.35-49.

BENEDDRA, T.; PICARD, C.; PETIT, A.; NESME, X. Correlation between susceptibility to crown gall and sensitivity to cytokinin in aspen cultivars. Phytopathology, v.86, n.2, p.225-231, 1996.

BERGMANN, B.A.; STOMP, A.M. Effect of host plant genotype and growth-rate on Agrobacterium tumefaciens-mediated gall formation in Pinus radiata. Phytopathology, v.82, n.12, p.1457-1462, 1992.

BERRIOS, E.F.; GENTZBITTEL, L.; SERIEYS, H.; ALIBERT, G.; SARRAFI, A. Influence of genotype and gelling agents on in vitro regeneration by organogenesis in sunflower. Plant Cell Tissue and Organ Culture, v.59, n.1, p.65-69, 1999.

BEYER, E.M. A potent inhibitor of ethylene action in plants. Plant Physiology, v.58, p.268-271, 1976.

BIDNEY, D.; SCELONGE, C.; MARTICH, J.; BURRUS, M.; SIMS, L.; HUFFMAN, G. Microprojectile bombardment of plant tissues increases transformation frequency by Agrobacterium tumefaciens. Plant Molecular Biology, v.18, n.2, p.301-313, 1992.

BIRCH, R.G. Plant transformation: Problems and strategies for practical application. Annual Review of Plant Physiology and Plant Molecular Biology, v.48, p.297326, 1997. 
BLEECKER, A.B.; KENDE, H. Ethylene: a gaseous signal molecule in plants. Annual Review of Cell and Developmental Biology, v.16, n.1, p.1-18, 2000.

BORNMAN, C.H.; VOGELMANN, T.C. Effect of rigidity of gel medium on benzyladenine-induced adventitious bud formation and vitrification in vitro in Picea abies. Physiologia Plantarum, v.61, n.3, p.505-512, 1984.

BRAND, M.H. Agar and ammonium nitrate influence hyperhydricity, tissue nitrate and total nitrogen-content of serviceberry (Amelanchier arborea) shoots in vitro. Plant Cell Tissue and Organ Culture, v.35, n.3, p.203-209, 1993.

BRAR, M.S.; MOORE, M.J.; AL-KHAYRI, J.M.; MORELOCK, T.E.; ANDERSON, E.J. Ethylene inhibitors promote in vitro regeneration of cowpea (Vigna unguiculata L.). In Vitro Cellular \& Developmental Biology-Plant, v.35, n.3, p.222-225, 1999.

BRASILEIRO, A.C.M.; CARNEIRO, V.T.D. Manual de transformação genética de plantas. Brasília: EMBRAPA,SPI; EMBRAPA, CENARGEN, 1998. 309p.

BRASILEIRO, A.C.M.; DUSI, D.M.D.A. Transformação genética de plantas. In: BRASILEIRO, A.C.M.; CARNEIRO, V.T.D. (Ed.). Manual de transformação genética de plantas. Brasília: EMBRAPA,SPI; EMBRAPA, CENARGEN, 1998. p.679-735.

BRASILEIRO, A.C.M.; ARAGÃO, F.J.L.; ROSSI, S.; DUSI, D.M.A.; BARROS, L.M.G.; RECH, E.L. Susceptibility of common and terapy beans to Agrobacterium spp. strains and improvement of Agrobacterium-mediated transformation using microprojectile bombardment. Journal of the American Society for Horticultural Science, v.121, n.5, p.810-815, 1996.

BRIGGS, B.A.; MCCULLOCH, S.M.; EDICK, L.A. Micropropagation of azaleas using thidiazuron. Acta Horticulturae , v.227, n.227, p.330-333, 1988.

BROWN, A.H.D.; CLEGG, M.T.; KAHLER, A.L.; WEIR, B.S. Plant population genetics, breeding, and genetic resources. UC Davis: International Symposium on Population Genetics and Germoplasm Resources in Crop Improvement, 1990. 449p.

CAPELLE, S.C.; MOK, D.W.S.; KIRCHNER, S.C.; MOK, M.C. Effects of thidiazuron on cytokinin autonomy and the metabolism of N-6-(delta-2-isopentenyl)[8-C14]adenosine in callus tissues of Phaseolus lanatus L. Plant Physiology, v.73, n.3, p.796-802, 1983.

CAPLAN, A.; HERRERA-ESTRELLA, L.; INZE, D.; VAN HAUTE, E.; VAN MONTAGU, M.; SHELL, J.; ZAMBRYSKI, P. Introduction of genetic material into plant cells. Science, v.222, n.4625, p.815-821, 1983.

CASTRO, L.B.A.D.; LACERDA, Z.; ARAMAYO, R.A.; SAMPAIO, M.J.A.M.; GANDER, E.S. Evidence for a precursor molecule of Brazil nut $2 S$ seed proteins from biosynthesis and cDNA analysis. Molecular and General Genetics, v.206, p.338343, 1987. 
CENTRO INTERNACIONAL DE AGRICULTURA TROPICAL - CIAT Common bean improvement. Cali, 2002. http://www.ciat.cgiar.org/beans/index.htm (16mai2002).

CHAKRAVARTY, T.N.; SOPORY, S.K. Blue light stimulation of cell proliferation and glyoxalase I activity in callus cultures of Amaranthus paniculatus. Plant Science, v.132, n.1, p.63-69, 1998.

CHAUVIN, J.E.; MARHADOUR, S.; COHAT, J.; LE NARD, M. Effects of gelling agents on in vitro regeneration and kanamycin efficiency as a selective agent in plant transformation procedures. Plant Cell Tissue and Organ Culture, v.58, n.3, p.213217, 1999.

CHILTON, M.D.; DRUMMOND, M.H.; MERLO, D.J.; SCIAKY, D.; MONTOYA, A.L.; GORDON, M.P.; NESTER, E.W. Stable incorporation of plasmid DNA into higher plant cells: molecular basis of crown gall tumorigenesis. The Cell, v.11, n.2, p.263271, 1977.

CLEENE, M.D.; DELEY, J. Host range of crown gall. Botanical Review, v.42, n.4, p.389-466, 1976.

COWAN, A.K.; CAIRNS, A.L.P.; BARTELS-RAHM, B. Regulation of abscisic acid metabolism: towards a metabolic basis for abscisic acid-cytokinin antagonism. Journal of Experimental Botany, v.50, n.334, p.595-603, 1999.

CROCOMO, O.J.; SHARP, W.R.; PETERS, J.C. Plantlet morphogenesis and the control of callus growth and root induction of Phaseolus vulgaris with the addition of bean seed extract. Zeitschrift für Pflanzenphysiologie, v.78, p.456-460, 1976.

DE ANDRADE, A. Avaliação de parâmetros que influenciam a transformação genética do Eucalyptus grandis via Agrobacterium. Piracicaba, 2001. 82p. Dissertação (Mestrado) - Escola Superior de Agricultura "Luiz de Queiroz", Universidade de São Paulo.

DE BLOCK, M. The cell biology of plant transformation: current state, probems prospects and the implication for plant breeding. Euphytica, v.71, p.1-14, 1993.

DE BLOCK, M.; BOTTERMAN, J.; VANDEWIELE, M.; DEKX, J.; THOEN, C.; GOSSELÉ, V.; MOVVA, N.R.; THONPSON, C.; VAN MONTAGU, M.; LEEMANS, J. Ingeneering herbicide in plants by expression of detoxifying enzyme. EMBO Journal, v.6, n.9, p.2513-2518, 1987.

DE CARVALHO, M.H.C.; LE, B.V.; ZUILY-FODIL, Y.; THI, A.T.P.; KIEM, T.T.V. Efficient whole plant regeneration of common bean (Phaseolus vulgaris L.) using thin-cell-layer culture and silver nitrate. Plant Science, v.159, n.2, p.223-232, 2000.

DEKATHEN, A.; JACOBSEN, H.J. Cell competence for Agrobacterium-mediated DNA transfer in Pisum sativum L. Transgenic Research, v.4, n.3, p.184-191, 1995. 
DI, R.; PURCELL, V.; COLLINS, G.B.; GHABRIAL, S.A. Production of transgenic soybean lines expressing the bean pod mottle virus coat protein precursor gene. Plant Cell Reports, v.15, n.10, p.746-750, 1996.

DILLEN, W.; DE CLERCQ, J.; VAN MONTAGU, M.; ANGENON, G. Plant regeneration from callus in a range of Phaseolus acutifolius A. Gray genotypes. Plant Science, v.118, p.81-88, 1996.

DILLEN, W.; DE CLERCQ, J.; GOOSSENS, A.; VAN MONTAGU, M.; ANGENON, G. Agrobacterium-mediated transformation of Phaseolus acutifolius A. Gray. Theoretical and Applied Genetics, v.94, p.151-158, 1997.

DITT, R.F.; NESTER, E.W.; COMAI, L. Plant gene expression response to Agrobacterium tumefaciens. Proceedings of the National Academy of Sciences of the United States of America, v.98, n.19, p.10954-10959, 2001.

EZURA, H.; YUHASHI, K.I.; YASUTA, T.; MINAMISAWA, K. Effect of ethylene on Agrobacterium tumefaciens-mediated gene transfer to melon. Plant Breeding, v.119, n.1, p.75-79, 2000.

FELLMAN, C.D.; READ, P.E.; HOSIER, M.A. Effects of thidiazuron and CPPU on meristem formation and shoot proliferation. Hortscience, v.22, n.6, p.1197-1200, 1987.

FIGUEIRA, A.; KODAMA, K.; SATHLER, I.; MAMANI, E.; TSAI, S.M. Determining genomic regions associated with common bean reaction to Agrobacterium tumefaciens infection. HortScience, v.34, n.3, p.453-453, 1999.

FINER, J.J.; MCMULLEN, M.D. Transformation of cotton (Gossypium hirsutum L.) via particle bombardment. Plant Cell Reports, v.8, n.10, p.586-589, 1990.

FIORE, S.; DE PASQUALE, F.; CARIMI, F.; SAJEVA, M. Effect of 2,4-D and 4-CPPU on somatic embryogenesis from stigma and style transverse thin cell layers of citrus. Plant Cell Tissue and Organ Culture, v.68, n.1, p.57-63, 2002.

FIROOZABADY, E.; KUEHNLE, A.R. Agrobacterium-mediated transformation. In: GAMBORG, O.L.; PHILLIPS, G.C. (Ed.). Plant cell, tissue and organ culture: fundamental methods. Berlin: Springer-Verlag, 1995. p.181-195.

FRALEY, R.T.; ROGERS, S.G.; HORSCH, R.B.; SANDERS, P.R.; FLICK, J.S.; ADAMS, S.P.; BITTNER, M.L.; BRAND, L.A.; FINK, C.L.; FRY, J.S.; GALLUPPI, G.R.; GOLDBERG, S.B.; HOFFMANN, N.L.; WOO, S.C. Expression of bacterial genes in plant cells. Proceedings of the National Academy of Sciences of the United States of America, v.80, n.15, p.4803-4807, 1983.

FRANCK, T.; CREVECOEUR, M.; WUEST, J.; GREPPIN, H.; GASPAR, T. Cytological comparison of leaves and stems of Prunus avium $\mathrm{L}$. shoots cultured on a solid medium with agar or gelrite. Biotechnic \& Histochemistry, v.73, n.1, p.32-43, 1998. 
FRANK, M.; SCHMÜLLING, T. Cytokinin cicles cells. Trends in Plant Sciences, v.4, n.7, p.243-244, 1999.

FRANKLIN, C.I.; TRIEU, T.N.; GONZALES, R.A.; DIXON, R.A. Plant regeneration from seedling explants of green bean (Phaseolus vulgaris L.) via organogenesis. Plant Cell, Tissue and Organ Culture, v.24, p.199-206, 1991.

GAMBORG, O.L.; PHILLIPS, G.C. Plant cell, tissue and organ culture: fundamental methods. Berlin: Springer-Verlag, 1995. 358p.

GAMBORG, O.L.; MILLER, R.A.; OJIMA, K. Nutrient requirements of suspension cultures of soybean root cells. Experimental Cell Research, v.50, p.151-158, 1968.

GELVIN, S.B. Agrobacterium and plant genes involved in T-DNA transfer and integration. Annual Review of Plant Physiology and Plant Molecular Biology, v.51, p.223-256, 2000.

GILL, R.; SAXENA, P.K. Direct somatic embryogenesis and regeneration of plants from seedling explants of peanut (Arachis hipogaea) - promotive role of thidiazuron. Canadian Journal of Botany, v.70, n.6, p.1186-1192, 1992.

GODWIN, I.D.; FORDLLOYD, B.V.; NEWBURY, H.J. In vitro approaches to extending the host-range of Agrobacterium for plant transformation. Australian Journal of Botany, v.40, n.6, p.751-763, 1992.

GONNEAU, J.; MORNET, R.; LALOUE, M. A Nicotiana plumbaginifolia protein labeled with an azido cytokinin agonist is a glutathione S-transferase. Physiologia Plantarum, v.103, n.1, p.114-124, 1998.

GOULD, J.; DEVEY, M.; HASEGAWA, O.; ULIAN, E.C.; PETERSON, G.; SMITH, R.H. Transformation of Zea mays L. using Agrobacterium tumefaciens and the shoot apex. Plant Physiology, v.95, p.426-436, 1991.

GRANT, J.E.; COOPER, P.A.; MCARA, A.E.; FREW, T.J. Transformation of peas (Pisum sativum L.) using immature cotyledons. Plant Cell Reports, v.15, p.254258, 1995.

GREENE, D.W. CPPU influences fruit quality and fruit abscission of 'Mclntosh' apples. Hortscience, v.36, n.7, p.1292-1295, 2001.

HADELER, B.; SCHOLZ, S.; RESKI, R. Gelrite and agar differently influence cytokininsensitivity of a moss. Journal of Plant Physiology, v.146, n.3, p.369-371, 1995.

HANGARTER, R.P.; STASINOPOULOS, T.C. Repression of plant tissue culture growth by light is caused by photochemical change in the culture medium. Plant Science, v.79, n.2, p.253-257, 1991.

HANSEN, G.; CHILTON, M.D. "Agrolistic" transformation of plant cells: integration of Tstrands generated in planta. Proceedings of the National Academy of Sciences of the United States of America, v.93, n.25, p.14978-14983, 1996. 
HANSEN, G.; WRIGHT, M.S. Recent advances in the transformation of plants. Trends in Plant Science, v.4, n.6, p.226-231, 1999.

HANSEN, G.; DAS, A.; CHILTON, M.D. Constituive expression of the virulence genes improves the efficiency of plant transformation by Agrobacterium. Proceedings of the National Academy of Sciences of the United States of America, v.91, n.16, p.7603-7607, 1994.

HAZRA, S.K.; DAS, S.; DAS, A.K. Sisal Plant Regeneration Via Organogenesis. Plant Cell Tissue and Organ Culture, v.70, n.3, p.235-240, 2002.

HELLENS, R.; MULLINEAUX, P.; KLEE, H. A guide to Agrobacterium binary Ti vectors. Trends in Plant Science, v.5, n.10, p.446-451, 2000.

HIEI, Y.; OHTA, S.; KOMARI, T.; KUMASHIRO, T. Efficient transformation of rice (Oryza sativa L) mediated by Agrobacterium and sequence-analysis of the boundaries of the T-DNA. Plant Journal, v.6, n.2, p.271-282, 1994.

HILDEBRANDT, A.C.; WILMAR, J.C.; JONES, H.; RIKER, A.J. Growth of edible chlorophyllous plant tissues in vitro. American Journal of Botany, v.50, p.248-254, 1963.

HODAL, L.; BOCHARDT, A.; NIELSEN, J.E.; MATTSSON, O.; OKKEKS, F.T. Detection expression and specific elimination of endogenous $\beta$-glucuronidase in transgenic and non-transgenic plants. Plant Science, v.87, p.115-121, 1992.

HOOD, E.E.; FRALEY, R.T.; CHILTON, M.D. Virulence of Agrobacterium tumefaciens strain-A281 om legumes. Plant Physiology, v.83, n.3, p.529-534, 1987.

HORSCH, R.B.; FRY, J.E.; HOFFMANN, N.L.; EICHHOLTZ, D.; ROGERS, S.G.; FRALEY, R.T. A simple and general-method for transferring genes into plants. Science, v.227, n.4691, p.1229-1231, 1985.

HOYOS, G.L.; HOSFIELD, G.L. Ethylene inhibitors added to in vitro culture media of common bean promotes morphogenesis of cotyledonary node explants. Annual Report of the Bean Improvement Cooperative, v.38, p.99-100, 1995.

HU, C.Y.; CHEE, P.P.; CHESNEY, R.H.; ZHOU, J.H.; MILLER, P.D. Intrinsic GUS-like activities in seed plants. Plant Cell Reports, v.9, p.1-5, 1990.

HUETTEMAN, C.A.; PREECE, J.E. Thidiazuron: a potent cytokinin for woody plant tissue culture. Plant Cell Tissue and Organ Culture, v.33, n.2, p.105-119, 1993.

HUSSEY, G.; JOHNSON, R.D.; WARREN, S. Transformation of meristematic cells in the shoot apex of cultured pea shoots by Agrobacterium tumefaciens and $A$. rhizogenes. Protoplasma, v.148, p.101-105, 1989.

ISHIDA, Y.; SAITO, H.; OHTA, S.; HIEI, Y.; KOMARI, T.; KUMASHIRO, T. High efficiency transformation of maize (Zea mays L.) mediated by Agrobacterium tumefaciens. Nature Biotechnology, v.14, n.6, p.745-750, 1996. 
JEFFERSON, R.A. Assaying chimeric genes in plant: the GUS gene fusion system. Plant Molecular Biology Reporter, v.5, p.387-405, 1987.

JEFFERSON, R.A.; BURGESS, S.M.; HIRSH, D. $\beta$-Glucuronidase from Escherichia coli as a gene-fusion marker. Proceedings of the National Academy of Sciences of the United States of America, v.83, n.22, p.8447-8451, 1986.

JEFFERSON, R.A.; KAVANAGH, T.A.; BEVAN, M.W. Gus fusions: $\beta$-glucuronidase as a sensitive and versatile gene fusion marker in higher plants. Embo Journal, v.6, n.13, p.3901-3907, 1987.

JIA, R.S.; YANG, M.Z.; OTT, R.; CHUA, N.H. High frequency transformation of Kalanchoe laciniata. Plant Cell Reports, v.8, p.336-340, 1989.

JIN, S.G.; KOMARI, T.; GORDON, M.P.; NESTER, E.W. Genes responsible for the supervirulence phenotype of Agrobacterium tumefaciens A281. Journal of Bacteriology, v.169, n.10, p.4417-25, 1987.

JOERSBO, M.; OKKELS, F.T. Calcium reduces toxicity of aminoglycoside antibiotics in sugar beet explants in vitro. Physiologia Plantarum, v.97, n.2, p.245-250, 1996.

JOERSBO, M.; BRUNSTEDT, J. Sonication: A new method for gene transfer to plants. Physiologia Plantarum, v.85, p.230-234, 1992.

JOHN, M.C.; AMASINO, R.M. Expression of an Agrobacterium Ti plasmid gene involved in cytokinin biosynthesis is regulated by virulence loci and induced by plant phenolic compounds. Journal of Bacteriology, v.170, n.2, p.790-795, 1988.

JULIANO, R.L.; HASKILL, S. Signal transduction from the extracellular matrix. The Journal of Cell Biology, v.120, p.577-585, 1993.

KAPAUN, J.A.; CHENG, Z.M. Aminoglycoside antibiotics inhibit shoot regeneration from Siberian elm leaf explants. Hortscience, v.34, n.4, p.727-729, 1999.

KARTHA, K.K.; PAHL, K.; LEUNG, N.L.; MROGINSKI, L.A. Plant regeneration from meristems of grain legumes: soybean, cowpea, peanut, chickpea and bean. Canadian Journal of Botany, v.59, p.1671-1679, 1981.

KHALAFALLA, M.M.; HATTORI, K. A combination of thidiazuron and benzyladenine promotes multiple shoot production from cotyledonary node explants of faba bean (Vicia faba L.). Plant Growth Regulation, v.27, n.3, p.145-148, 1999.

KHALAFALLA, M.M.; HATTORI, K. Ethylene inhibitors enhance in vitro root formation on faba bean shoots regenerated on medium containing thidiazuron. Plant Growth Regulation, v.32, n.1, p.59-63, 2000.

KIM, J.W.; MINAMIKAWA, T. Transformation and regeneration of french bean plants by the particle bonbardment process. Plant Science, v.117, p.131-138, 1996.

KLEIN, T.M.; WOLF, E.D.; WU, R.; SANFORD, J.C. High velocity microprojectiles for delivering nucleic-acids into living cells. Nature, v.327, n.6117, p.70-73, 1987. 
KONCZ, C.; NEMETH, N.; REDEI, G.P.; SCHELL, J. T-DNA insertional mutagenesis in Arabidopsis. Plant Molecular Biology, v.20, p.963-976, 1992.

KOSEMURA, S.; NIWA, K.; EMORI, H.; YOKOTANITOMITA, K.; HASEGAWA, K.; YAMAMURA, S. Light-induced auxin-inhibiting substance from cabbage (Brassica oleaceae L. shoots. Tetrahedron Letters, v.38, n.48, p.8327-8330, 1997.

KUMAR, A.S.; GAMBORG, O.L.; NABORS, M.W. Regeneration from long-term cellsuspension cultures of tepary bean (Phaseolus acutifolius). Plant Cell Reports , v.7, n.5, p.322-325, 1988.

LACORTE, C. $\beta$-glucoronidase (GUS). In: BRASILEIRO, A.C.M.; CARNEIRO, V.T.D. (Ed.). Manual de transformação genética de plantas. Brasília: EMBRAPA,SPI; EMBRAPA, CENARGEN, 1998. p.127-141.

LAINE, E.; LAMBLIN, F.; LACOUX, J.; DUPRE, P.; ROGER, D.; SIHACHAKR, D.; DAVID, A. Gelling agent influences the detrimental effect of kanamycin on adventitious budding in flax. Plant Cell Tissue and Organ Culture, v.63, p.77-80, 2000.

LESHEM, B.; RONEN, R.; LURIE, S. Thidiazuron and paclobutrazol appear to mimic cytokinin and auxin influences on organ regeneration and protein profiles in cultured melon cotyledons. Journal of Plant Physiology, v.143, n.3, p.344-348, 1994.

LINDSEY, K. Genetic transformation of crop plants. Journal of Biotechnology, v.26, p.1-28, 1992.

LIU, C.Z.; MOON, K.; HONDA, H.; KOBAYASHI, T. Enhanced regeneration of rice (Oryza sativa L.) embryogenic callus by light irradiation in growth phase. Journal of Bioscience and Bioengineering, v.91, n.3, p.319-321, 2001.

MALIK, K.A.; SAXENA, P.K. Regeneration in Phaseolus vulgaris L - promotive role of N6-benzylaminopurine in cultures from juvenile leaves. Planta, v.184, n.1, p.148150, 1991.

MALIK, K.A.; SAXENA, P.K. Regeneration in Phaseolus vulgaris L - High-frequency induction of direct shoot formation in intact seedlings by N-6- benzylaminopurine and thidiazuron. Planta, v.186, n.3, p.384-389, 1992a.

MALIK, K.A.; SAXENA, P.K. Thidiazuron induces high-frequency shoot regeneration in intact seedlings of pea (Pisum ativum), chickpea (Cicer arietinum) and lentil (Lens culinaris). Australian Journal of Plant Physiology, v.19, n.6, p.731-740, 1992b.

MARGA, F.; VEBRET, L.; MORVAN, H. Agar fractions could protect apple shoots cultured in liquid media against hyperhydricity. Plant Cell Tissue and Organ Culture, v.49, n.1, p.1-5, 1997.

MARIOTTI, D.; FONTANA, G.S.; SANTINI, L. Genetic transformation of grains legumes: Phaseolus vulgaris L. and $P$. coccineus L. Journal of Genetics \& Breeding, v.43, p.77-82, 1989. 
MARTINS, I.S.; SONDAHL, M.R. Early stages of somatic embryo differentiation from callus cells of bean (Phaseolus-Vulgaris L.) grown in liquid-medium. Journal of Plant Physiology, v.117, n.2, p.97-103, 1984.

MAURO, A.O.; PFEIFFER, T.W.; COLLINS, G.B. Inheritance of soybean susceptibility to Agrobacterium tumefaciens and its relationship to transformation. Crop Science, v.35, n.4, p.1152-1156, 1995.

MCCLEAN, P.; GRAFTON, K.F. Regeneration of dry bean (Phaseolus vulgaris $L$ ) via organogenesis. Plant Science, v.60, n.1, p.117-122, 1989.

MCCORMAC, A.C.; ELLIOT, M.C.; CHEN, D.-F. pBECKS2000: a novel plasmid series for the facile creation of complex binari vectors, which incorporates "clean-gene" facilities. Molecular and General Genetics, v.261, p.226-235, 1999.

MCKENTLY, A.H.; MOORE, G.A.; DOOSTDAR, H.; NIEDZ, R.P. Agrobacteriummediated transformation of peanut (Arachis hypogaea $L$ ) embryo axes and the development of transgenic plants. Plant Cell Reports, v.14, n.11, p.699-703, 1995.

MEDFORD, F.I. Vegetative apical meristems. Plant Cell, v.4, n.9, p.1029-1039, 1992.

MILLER, M.W.; VOORHEES, S.M.; CARSTENS.EL; EAMES, F.A. An histological study of effect of ultrasound on growth of Vicia faba roots. Radiation Botany, v.14, n.3, p.201-206, 1974.

MOHAMED, M.F.; READ, P.E.; COYNE, D.P. Dark preconditioning, CPPU, and thidiazuron promote shoot organogenesis on seedling node explants of common and faba beans. Journal of the American Society for Horticultural Science, v.117, n.4, p.668-672, 1992a.

MOHAMED, M.F.; READ, P.E.; COYNE, D.P. Plant-regeneration from in vitro culture of embryonic axis explants in common and tepary beans. Journal of the American Society for Horticultural Science, v.117, n.2, p.332-336, 1992b.

MOHAMED, M.F.; COYNE, D.P.; READ, P.E. Enhanced differentiation of somatic embryoids in callus cultures of common bean. Annual Report of the Bean Improvement Cooperative, v.36, p.16-17, 1993a.

MOHAMED, M.F.; COYNE, D.P.; READ, P.E. Shoot organogenesis in callus induced from pedicel explants of common bean (Phaseolus vulgaris $\mathrm{L}$ ). Journal of the American Society for Horticultural Science, v.118, n.1, p.158-162, $1993 \mathrm{~b}$.

MOK, M.C.; MOK, D.W.S. The metabolism of $\left[{ }^{14} \mathrm{C}\right]$ thidiazuron in callus tissues of Phaseolus lanatus. Physiologia Plantarum, v.65, n.4, p.427-432, 1985.

MOK, M.C.; MOK, D.W.S.; ARMSTRONG, D.J.; SHUDO, K.; ISOGAI, Y.; OKAMOTO, T. Cytokinin activity of N-phenyl-N'-1,2,3-thidiazol-5-ylurea (Thidiazuron). Phytochemistry, v.21, p.1509-1511, 1982. 
MULLINS, K.V.; LLEWELLYN, D.J.; HARTNEY, V.J.; STRAUSS, S.; DENNIS, E.S. Regeneration and transformation of Eucalyptus camaldulensis. Plant Cell Reports, v.16, n.11, p.787-791, 1997.

MURASHIGE, T.; SKOOG, F. A revised medium for rapid growth and bio assays with tabacco tissue cultures. Physiologia Plantarum, v.15, n.3, p.473-497, 1962.

MURCH, S.J.; SAXENA, P.K. Molecular fate of thidiazuron and its effects on auxin transport in hypocotyls tissues of Pelargonium $\mathrm{x}$ hortorum Bailey. Plant Growth Regulation, v.35, n.3, p.269-275, 2001.

MURTHY, B.N.S.; SAXENA, P.K. Somatic embryogenesis in peanut (ArachisHypogaea L. - stimulation of direct differentiation of somatic embryos by forchlorfenuron (CPPU). Plant Cell Reports, v.14, n.2-3, p.145-150, 1994.

NAGL, W.; IGNACIMUTHU, S.; BECKER, J. Genetic engineering and regeneration of Phaseolus and Vigna. State of the art and new attempts. Journal of Plant Physiology, v.150, p.625-644, 1997.

NAIRN, B.J.; FURNEAUX, R.H.; STEVENSON, T.T. Identification of an agar constituent responsible for hydric control in micropropagation of radiata pine. Plant Cell Tissue and Organ Culture, v.43, n.1, p.1-11, 1995.

NAM, J.; MATTHYSSE, A.G.; GELVIN, S.B. Differences in susceptibility of Arabidopsis ecotypes to crown gall disease may result from a deficiency in T-DNA integration. Plant Cell, v.9, n.3, p.317-333, 1997.

NEUHAUS, G.; SPANGENBERG, G. Plant transformation by microinjection techniques. Physiologia Plantarum, v.79, p.213-217, 1990.

NORDSTRÖM, A.C.; ELIASSON, L. Interaction of ethylene with indole-3-acetic acid in regulation of rooting in pea cuttings. Plant Growth Regulation, v.12, p.83-90, 1993.

NOVOA, C.O.; COLES, G. Computer image analysis to quantify and análise stable transformation identified using the histochemical GUS assay. Plant Molecular, v.12, p.146-151, 1994.

OHBA, T.; YOSHIOKA, Y.; MACHIDA, C.; MACHIDA, Y. DNA rearrangement associated with the integration of T-DNA in tobacco: an example for multiple duplications of DNA around the integration target. The Plant Journal, v.7, p.157164, 1995.

PHILLIPS, G.C.; HUBSTENBERGER, J.F.; HANSEN, E.E. Plant regeneration by organogenesis from callus and cell suspension cultures. In: GAMBORG, O.L.; PHILLIPS, G.C. (Ed.). Plant cell, tissue and organ culture: fundamental methods. Berlin: Springer-Verlag, 1995. p.67-79.

PICKARDT, T.; MEIXNER, M.; SCHADE, V.; SCHIEDER, O. Transformation of Vicia narbonensis via Agrobacterium-mediated gene transfer. Plant Cell Reports, v.9, p.535-538, 1991. 
PLEGT, L.; BINO, R.J. $\beta$-glucuronidase activity during development of the male gametophyte from transgenic and non-transgenic plants. Molecular and General Genetics, v.216, p.321-327, 1989.

POTRYKUS, I. Gene transfer to plants: assessment of published approaches and results. Annual Review of Plant Physiology and Plant Molecular Biology, v.42, p.205-225, 1991.

POTRYKUS, I.; SPANGENBERG, G. Gene transfer to plants. Berlin: SpringerVerlag, 1995. 361p.

REAL, M.J.V.D. Efeito do aumento do complexo protéico clorofila a/b no metabolismo fotossintético de plantas transgênicas de tabaco (Nicotiana tabacum). Piracicaba, 1997. 150p. Tese (Doutorado) - Escola Superior de Agricultura "Luiz de Queiroz", Universidade de São Paulo.

REAM, W. Agrobacterium tumefaciens and interkingdom genetic exchange. Annual Review of Phytopathology, v.27, p.583-586, 1989.

RECH, E.L.; ARAGÃO, F.J.L. Biobalística. In: BRASILEIRO, A.C.M.; CARNEIRO, V.T.D. (Ed.). Manual de transformação genética de plantas. Brasília: EMBRAPA,SPI; EMBRAPA, CENARGEN, 1998. p.51-64.

REYNOLDS, A.G.; WARDLE, D.A.; ZUROWSKI, C.; LOONEY, N.E. Phenylureas CPPU and thidiazuron affect yield components, fruit composition, and storage potential of 4 seedless grape selections. Journal of the American Society for Horticultural Science, v.117, n.1, p.85-89, 1992.

RITCHIE, S.W.; LUI, C.N.; SELLMER, J.C.; KONONOWICZ, H.; HODGES, T.K.; GELVIN, S.B. Agrobacterium tumefaciens-mediated expression of gusA in maize tissues. Transgenic Research, v.2, n.5, p.252-265, 1993.

RIVA, G.A.D.L.; GONZÁLEZ-CABRERA, J.; VÁZQUEZ-PADRÓN, R.; AYRA-PARDO, C. Agrobacterium tumefaciens: a natural tool for plant transformation. Eletronic Journal of Biotechnology, v.1, n.3, p.1-16, 1998.

ROBBS, S.L.; HAWES, M.C.; LIN, H.J.; PUEPPKE, S.G.; SMITH, L.Y. Inheritance of resistance to crown gall in Pisum sativum. Plant Physiology, v.95, n.1, p.52-57, 1991.

RUSSELL, D.R.; WALLACE, K.M.; BATHE, J.H.; MARTINELL, B.J.; MCCABE, D.E. Stable transformation of Phaseolus vulgaris via electric-discharge mediated particleacceleration. Plant Cell Reports, v.12, n.3, p.165-169, 1993.

SAAM, M.M.; HOSFIELD, G.L.; SAUNDERS, J.W. In vitro propagation of dry bean from seedling shoot tips. Journal of the American Society for Horticultural Science, v.112, p.852-855, 1987.

SANFORD, J.C. Biolistic plant transformation. Physiologia Plantarum, v.79, n.1, p.206-209, 1990. 
SANFORD, J.C.; SMITH, F.D.; RUSSELL, J.A. Optimizing the biolistic process for different biological applications. Methods in Enzymology, v.217, p.483-509, 1993.

SANGWAN, R.S.; BOURGEOIS, Y.; BROWN, S.; VASSEUR, G.; SANGWANNORREEL, B. Characterization of competent cells and early events of Agrobacterium-mediated genetic transformation in Arabidopsis thaliana. Planta, v.188, n.3, p.439-456, 1992.

SANTARÉM, E.R. SAAT: Transformação de plantas mediada por ultra-som e Agrobacterium. Ciência Rural, v.30, n.4, p.725-730, 2000.

SANTARÉM, E.R.; TRICK, H.N.; ESSIG, J.S.; FINER, J.J. Sonication Assisted Agrobacterium-Mediated Transformation of Soybean Immature Cotyledons: Optimization of Transient Expression. Plant Cell Reports, v.17, n.10, p.752-759, 1998.

SANTOS, M.L.D.; BRAGA, M.J. Aspectos econômicos. In: VIEIRA, C.; PAULA JUNIOR., T.J.D.; BORÉM, A. (Ed.). Feijão: aspectos gerais e a cultura no estado de Minas Gerais. Viçosa: UFV, 1998. p.19-53.

SAUNDERS, J.W.; HOSFIELD, G.L.; LEVI, A. Morphogenetic effects of 2,4dichlorophenoxyacetic acid on pinto bean (Phaseolus vulgaris L.) leaf explants in vitro. Plant Cell Reports, v.6, p.46-49, 1987.

SAWAHEL, W.A. Ultrasound-mediated stable transformation of potato tuber discs. Biotechnology Techniques, v.10, n.11, p.821-824, 1996.

SCHELL, J.; VAN MONTAGU, M.; HERNALSTEENS, J.P.; WILLMITZER, L.; LEEMANS, J.; JOOS, H.; OTTEN, L.; DEGREVE, H.; HOLSTERS, M.; ZAMBRYSKI, P.; HERRERA, L.; DEPICKER, A. Transfer and expression of foreign genes in plants. DNA - A Journal of Molecular \& Cellular Biology, v.2, n.2, p.165, 1983.

SCHLÄPPI, M.; HOHN, B. Competence of immature maize embryos for Agrobacterium mediated gene-transfer. Plant Cell, v.4, n.1, p.7-16, 1992.

SCHOLTEN, H.J.; PIERIK, R.L.M. Agar as a gelling agent: chemical and physical analysis. Plant Cell Reports, v.17, n.3, p.230-235, 1998a.

SCHOLTEN, H.J.; PIERIK, R.L.M. Agar as a gelling agent: differential biological effects in vitro. Scientia Horticulturae, v.77, n.1-2, p.109-116, 1998 b.

SCHOONHOVEN, A.V.; VOYSEST, O. Common beans: research for crop improvement. Cali: CIAT; CAB International, 1991. 980p.

SCHROEDER, H.E.; SCHOTZ, A.H.; WARDLEYRICHARDSON, T.; SPENCER, D.; HIGGINS, T.J.V. Transformation and regeneration of 2 cultivars of pea (Pisum sativum L.). Plant Physiology, v.101, n.3, p.751-757, 1993. 
SCORZA, R.; CORDTS, J.M.; RAMMING, D.W.; EMERSHAD, R.L. Transformation of grape (Vitis vinifera L) zygotic-derived somatic embryos and regeneration of transgenic plants. Plant Cell Reports, v.14, n.9, p.589-592, 1995.

SHEN, W.H.; ESCUDERO, J.; SCHLAPPI, M.; RAMOS, C.; HOHN, B.; KOUKOLIKOVANICOLA, Z. T-DNA transfer to maize cells - histochemical investigation of $\beta$-glucuronidase activity in maize tissues. Proceedings of the National Academy of Sciences of the United States of America, v.90, n.4, p.1488-1492, 1993.

SMARRELLI, J.; WATTERS, M.T.; DIBA, L.H. Response of various cucurbits to infection by plasmid-harboring strains of Agrobacterium. Plant Physiology, v.82, n.2, p.622-624, 1986.

SONGSTAD, D.D.; SOMERS, D.A.; GRIESSBACH, R.J. Advances in alternative DNA delivery techniques. Plant Cell Tissue and Organ Culture, v.40, p.1-15, 1995.

SRISKANDARAJAH, S.; FRELLO, S.; SEREK, M. Induction of adventitious shoots in vitro in Campanula carpatica. Plant Cell Tissue and Organ Culture, v.67, n.3, p.295-298, 2001.

STACHEL, S.E.; MESSENS, E.; VAN MONTAGU, M.; ZAMBRISKI, P. Identification of the signal molecules produced by wounded plant cells that activate T-DNA transfer in Agrobacterium tumefaciens. Nature, v.318, n.6047, p.624-629, 1985.

SUTTLE, J.C. Involvement of ethylene in the action of the cotton defoliant thidiazuron. Plant Physiology, v.78, n.2, p.272-276, 1985.

TAKAHASHI, S.; SHUDO, K.; OKAMOTO, T.; YAMADA, K.; ISOGAI, Y. Cytokinin activity of $N$-phenyl- $N$ '-(4-pyridyl)urea derivates. Phytochemistry, v.17, p.12011207, 1978.

THOMAS, J.C.; KATTERMAN, F.R. Cytokinin activity induced by thidiazuron. Plant Physiology, v.81, n.2, p.681-683, 1986.

THORPE, T.A. In vitro embryogenesis in plants. Dordrecht: Kluwer Academic Publishers, 1995. 558p. (Current Plant Science and Biotechnology in Agriculture, 20)

TINLAND, B. The integration of T-DNA into plant genomes. Trends in Plant Science, v.1, n.6, p.178-184, 1996.

TÖR, M.; MANTELL, S.H.; AINSWORTH, C. Endophytic bacteria expressing $\beta$ glucuronidase cause false positive in Discorea species. Plant Cell Reports, v.11, p.452-456, 1992.

TRICK, H.N.; FINER, J.J. SAAT: Sonication-assisted Agrobacterium-mediated transformation. Transgenic Research, v.6, n.5, p.329-336, 1997. 
TZFIRA, T.; VAIDYA, M.; CITOVSKY, V. Increasing plant susceptibility to Agrobacterium infection by overexpression of the Arabidopsis nuclear protein VIP1. Proceedings of the National Academy of Sciences of the United States of America, v.99, n.16, p.10435-10440, 2002.

TRICK, H.N.; FINER, J.J. Sonication assisted Agrobacterium-mediated transformation of soybean [Glycine max (L.) Merrill] embryogenic suspension culture tissue. Plant Cell Reports, v.17, n.6-7, p.482-488, 1998.

TZFIRA, T.; CITOVSKY, V. Partners-in-infection: host proteins involved in the transformation of plant cells by Agrobacterium. Trends in Cell Biology, v.12, n.3, p.121-129, 2002.

ULIAN, E.C.; SMITH, R.H.; GOULD, J.H.; MCKNIGHT, T.D. Transformation of plants via the shoot apex. In vitro Cellular \& Developmental Biology, v.24, n.9, p.951954, 1988.

VAN REKEL, J.S.C.; DAMM, B.; MELCHERS, L.S.; HOEKEMA, A. Factors influencing transformation frequency of tomato (Lycopersicon esculentum). Plant Cell Reports, v.12, n.11, p.644-647, 1993.

VASIL, V.; BROWN, S.; RE, D.; FROMM, M.E.; VASIL, I. Stable transformed callus line from microprojectile bombardement of the cells suspension cultures of wheat. Biotechnology, v.9, p.743-747, 1991.

VERGUNST, A.C.; HOOYKAAS, J.P. Recombination in the plant genome and its application in biotechnology. Critical Review in Plant Science, v.18, n.1, p.1-31, 1999.

VIEIRA, C.; PAULA JR., T.J.D.; BORÉM, A. Feijão: aspectos gerais e a cultura no estado de Minas Gerais . Viçosa: UFV, 1998. 596p.

WANG, S.Y.; STEFFENS, G.L.; FAUST, M. Breaking bud dormancy in apple with a plant bioregulator, thidiazuron. Phytochemistry, v.25, n.2, p.311-317, 1986.

WEISING, K.; KAHL, G. Natural genetic engineering of plant cells: The molecular biology of crown gall and hairy root disease. World Journal of Microbiology \& Biotechnology, v.12, n.4, p.327-351, 1996.

WILMINK, A.; DONS, J.J.M. Selective agents and markers genes for use in transformation of monocotyledonous plants. Plant Molecular Biology Reporter, v.11, n.2, p.165-185, 1993.

YANG, S.F. Biosynthesis and action of ethylene. HortScience, v.20, p.41-45, 1985.

ZAMBRE, M.A.; DE CLERCQ, J.; VRANOVÁ, E.; VAN MONTAGU, M.; ANGENON, G.; DILLEN, W. Plant regeneration from embryo-derived callus in Phaseolus vulgaris $L$. (common bean) and $P$. acutifolius A. Gray (tepary bean). Plant Cell Reports, v.17, p.626-630, 1998. 
ZAMBRE, M.; GEERTS, P.; MAQUET, A.; VAN MONTAGU, M.; DILLEN , W.; ANGENON, G. Regeneration of fertile plants from callus in Phaseolus polyanthus Greenman (Year Bean). Annals of Botany, v.88, p.371-377, 2001.

ZAMBRYSKI, P.C. Chronicles from the Agrobacterium-plant cell-DNA transfer story. Annual Review of Plant Physiology and Plant Molecular Biology, v.43, p.465490, 1992.

ZHANG, L.J.; CHENG, L.M.; XU, N.; ZHAO, N.M.; LI, C.G.; YUAN, J.; JIA, S.R. Efficient transformation of tabacco by ultrasonication. Bio-Technology, v.9, n.10, p.996-997, 1991.

ZUPAN, J.; MUTH, T.R.; DRAPER, O.; ZAMBRYSKI, P. The transfer of DNA from Agrobacterium tumefaciens into plants: a feast of fundamental insights. Plant Journal, v.23, n.1, p.11-28, 2000. 


\section{E R R A T A}

1) Nas páginas 66 e 68 substituir a palavra npt/l pela palavra neo.

2) Substituir a página 79 (Conclusões gerais) por:

\section{CONCLUSÕES GERAIS}

O sistema de regeneração indireta de feijão (linhagem Xan 159) apresenta boa eficiência, sendo possível obter plantas sexualmente férteis a partir de calo.

A linhagem de Agrobacterium LBA 4404 (pTOK 233) apresenta a maior virulência, avaliando-se pela expressão transiente da ß-glucuronidase, aos 5 dias após a inoculação. 